Social Inequality and the Dynamics of Political and Ethnolinguistic Divides in Pakistan, 1970-2018

\author{
Amory Gethin, Sultan Mehmood, \\ Thomas Piketty
}

August 2020

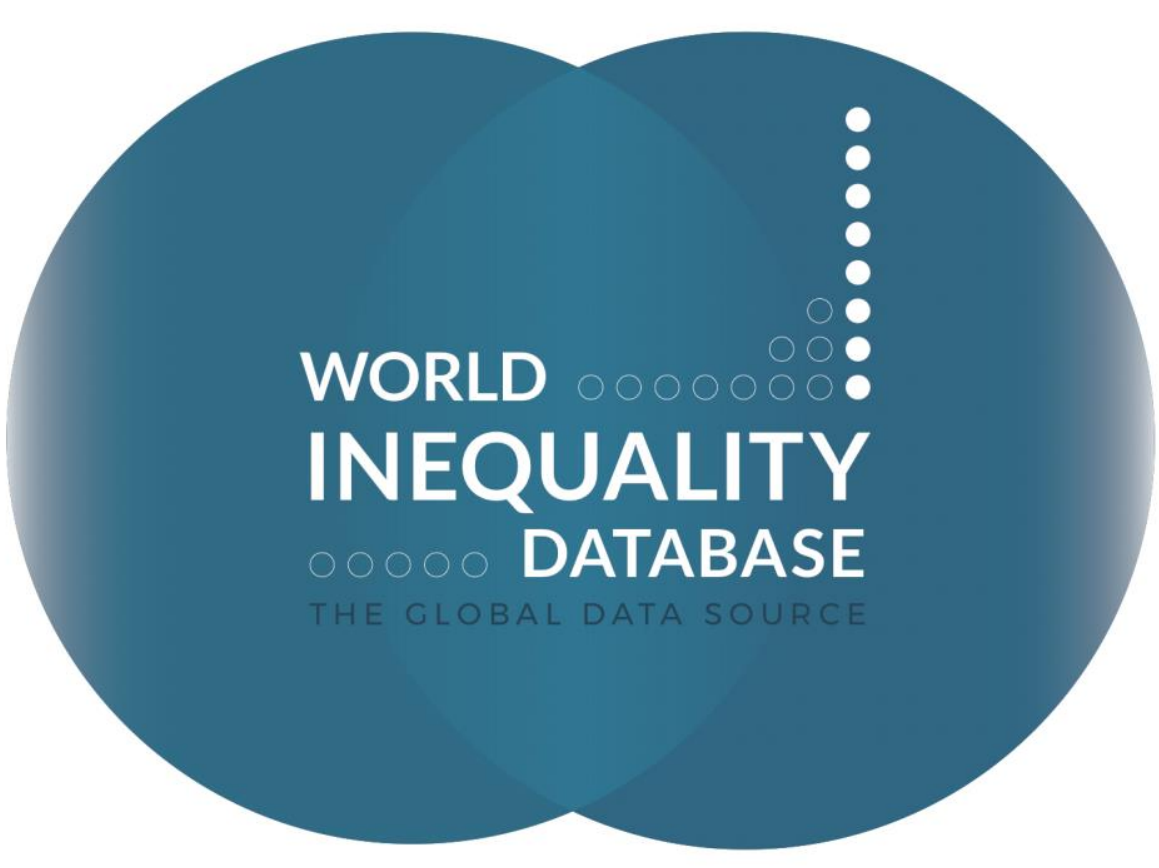

World Inequality Lab 


\title{
Social Inequality and the Dynamics of Political and Ethnolinguistic Divides in Pakistan, 1970-2018 ${ }^{1}$
}

\author{
Amory Gethin \\ Sultan Mehmood \\ Thomas Piketty
}

August 2020

\begin{abstract}
This study documents the changing structure of Pakistan's political cleavages by making use of a unique set of exit polls covering every direct election held in the country between 1970 and 2018. We analyze the evolution of the party system, beginning with the initial economic "left-right" opposition between the Pakistan Peoples Party (PPP) and the Muslim Leage. Regionalist, ethnolinguistic and religious divides have weakened and transformed this party system. The decline of the PPP has come with its transformation from a lowincome mass-based party to an ethnic party confined to Sindhi speakers. We also analyze the recent rise of the Pakistan Tehreek-e-Insaf and the role played by the political unification of the various economic, religious and military elites in its success. Finally, we discuss how the Islamization policies implemented under the military regime of Zia-ul-Haq (1977-1988) have contributed to weaken the development of a pro-redistribution secularist coalition.
\end{abstract}

\footnotetext{
${ }^{1}$ Gethin: Paris School of Economics - World Inequality Lab; Mehmood: Aix-Marseille School of Economics; Piketty: Paris School of Economics - World Inequality Lab. We are grateful to Christophe Jaffrelot, Saad Gulzar, and Clara Martínez-Toledano for their useful suggestions, as well as to Gallup Pakistan for providing us with the polling data used in this paper.
} 


\section{Introduction}

A number of recent studies have combined available surveys to document the long-run transformation of political cleavages in a number of countries, including the United States, the United Kingdom and France (Piketty 2018), India (Banerjee, Gethin and Piketty 2018) or South Africa (Gethin 2020). By focusing on the role of socio-economic variables, in particular income, wealth and education in determining the vote, these studies have attempted to better understand how inequalities are politically represented in the democratic arena and how this representation evolves in the long run of history.

This paper contributes to this literature by studying the changing structure of Pakistan's political cleavages thanks to the use of a unique set of exit polls covering every direct election held in the world's second largest Muslim-majority country between 1970 and 2018. The history of Pakistan as an independent State began in 1947, when the partition of the Indian subcontinent led to the creation of a country defined primarily by its religion: Islam. Aside from this defining trait of the new political community, Pakistan was and has remained a highly heterogeneous and fractured nation, divided across regional and ethnolinguistic identities. The confrontation between this persistent diversity and the obsession of political elites to impose a centralized nation state has led to deep-seated conflicts and lasting institutional instability (Jaffrelot 2015). This instability culminated in the Bangladesh War of Independence of 1971 and the separation of East and West Pakistan, which resulted from the refusal of West Pakistani elites to accept the electoral victory of the Awami Party dominating East Pakistan. It has also manifested itself in the repeated alternation of military and democratic regimes, as well as in the strong ethnic and regional dimensions of party politics.

In this paper, we take a historical perspective on the relationship between the State, ethnolinguistic diversity, and inequality by documenting the long-run evolution of Pakistan's party system and the changing determinants of political parties' support between 1970 and 2018.

Our analysis reveals at least three key dimensions of political conflicts which have manifested themselves in the electoral arena. The first one has to do with a primarily economic "left-right" 
division opposing the Pakistan Peoples Party (PPP) to the more pro-capitalist, elite-supported Muslim League parties. This cleavage has interacted with ethnicity and language, which have remained the strongest predictors of electoral behaviors since 1970. We also show that oppositions between political parties have been characterized by a third, enduring division between secular and religious visions of the nation, which has manifested itself in the strong support for the PPP among Shia Muslims and other religious minorities, as well as in the persistence of significant vote shares accruing to Islamic parties.

Finally, we discuss the long-run transformation of the political space from popular left-wing politics to right-wing and Islamic policies by emphasizing the role played by General Zia-ul-Haq's military regime. Zia's regime notably introduced Islamization policies, such as consolidation of Blasphemy law, introduction of Shariat courts and changing school curriculum to include Islamist content that may have had far reaching consequences for electoral politics in Pakistan. We also explain the recent rise of Imran Khan's Pakistan Tehreek-e-Insaf (PTI), a party with broad support across former left-wing voters as well as Islamic ideological voters through a successful political coalition facilitated by the military and landed political and industrial elites.

The next section provides a brief history of Pakistani democracy, followed by a more detailed description of the evolution of the party system since 1970. We then discuss the relationships between language, geography and inequality in Pakistan and study in detail the changing structure of ethnolinguistic divides, class cleavages and their intersection in light of our electoral data. We finally conclude this paper by focusing on the representation of religious minorities and the role of Zia-ul-Haq's policies in accounting for the long-run transformation of Pakistan's party system.

\section{Independence, Military Dictatorship, and Electoral Contests: The Making of Pakistani Democracy}

Following independence of India and Pakistan from British colonial rule in 1947, the state of Pakistan was constituted consisting of East Pakistan (that is modern day Bangladesh) and West Pakistan (that is modern day Pakistan). After the division of the subcontinent, two elections took place in Pakistan, one in 1954 and another in 1962, however, they were indirect and highly 
controversial since they were not based on adult franchise and the latter was held under direct military rule. The first direct elections based on adult franchise in Pakistan took place in 1970. The Awami Party, led by Sheikh Mujib from East Pakistan obtained the absolute majority with about 40 percent of the popular vote followed by 20 percent of the votes for the West Pakistani Pakistan Peoples Party (PPP) (Bose and Jalal 2017). ${ }^{2}$

The Pakistan Peoples Party and President General Yahya Khan did not want a Bengali ethnic "minority" party from East Pakistan to form the government and the assembly was never invited by the President to form the government, as per the constitutional requirement. This caused great unrest in what was formerly East Pakistan, which escalated into a civil war and eventually led to the formation of the state of Bangladesh in 1971. After the formation of Bangladesh as an independent nation, President Yahya Khan resigned, and the PPP's founding leader, Zulfiqar Ali Bhutto, took over as the first civilian chief Martial law administrator and President. It was during the tenure of Zulfiqar Ali Bhutto that the new constitution of Pakistan was passed and ratified by all provinces in 1973. This led Bhutto to relinquish the presidency as he was elected as Prime Minister by the legislature.

Bhutto's legacy not only includes being the first civilian martial law administrator, but also the implementation of socialist policies which included land reforms, nationalization of industries and succeeding in getting the constitution passed by the national and provincial assemblies in an ethnically fractious nation. Nevertheless, Bhutto was removed through a military coup by General Zia-ul-Haq and convicted of planning the assassination of a political rival. He was executed in a controversial 3-2 decision by the Pakistan's Supreme Court during General Zia's military regime. General Zia built a relatively stable political coalition with Islamic, right-wing political parties and

\footnotetext{
${ }^{2}$ See appendix Table A1 for figures on the share of seats received by groups of parties in the 1970 provincial elections, which were held ten days after the general elections. The Awami Party won 288 of 300 seats in East Pakistan and no seat in West Pakistan. West Pakistani provinces were more divided, with the Pakistan Peoples Party receiving the greatest share of seats in Punjab and Sindh, while Muslim League parties were stronger in the North-West Frontier Province and in Baluchistan.
} 
religious leaders and managed to stay in power for eleven years (the longest serving head of State in Pakistan). His rule is widely considered to be a time of political repression and Islamization reforms (Mehmood and Seror 2020). However, General Zia died in a plane crash on $17^{\text {th }}$ August 1988. Following a hardly fought election between General Zia's allies and the opposition led by Benazir Bhutto (the daughter of Zulfiqar Ali Bhutto), Benazir Bhutto rose to power.

The 1990s to 1999 was a period of political tussle between two parties, the center-left Pakistan Peoples Party led by Benazir Bhutto and center-right Pakistan Muslim League led by Nawaz Sharif. These two parties and individuals revolved in power until October 1999, when General Pervez Musharraf seized power through a military coup. Pakistan once again came under direct military rule, with General Musharraf winning a controversial referendum in 2002 which gave him five years in office. However, conflict with the judiciary and a mass political movement led by lawyers against him weakened his grasp on power. The December 2007 assassination of Benazir Bhutto under Musharraf's watch was the final nail in his political coffin, and General Musharraf resigned a day before impeachment proceedings were to start against him in 2008. There has been no direct military rule in Pakistan since then. Nevertheless, the 2018 elections brought to power what many commentators believe to be a military establishment backed political party, the Pakistan Tehreek-e-Insaf, led by former cricketer Imran Khan (see for instance Behra 2018; Shah 2019; Wolf 2020).

\section{The Evolution of Pakistan's Party System, 1970-2018}

This paper focuses on the evolution of Pakistan's party system since the division between East and West Pakistan in 1970. Who have been the main contenders of democratic elections in contemporary Pakistan in the past forty years, and which coalitions of voters have they relied upon? Three groups of parties have historically received the highest shares of popular votes: the Pakistan Muslim League (PML), the Pakistan Peoples Party (PPP), and, in 2018, the Pakistan 
Tehreek-e-Insaf (see Figure 1). ${ }^{3}$ The Muslim League, as was originally known, was a successor to All-India Muslim League led by Muhammad Ali Jinnah that spearheaded the movement to obtain Pakistan. ${ }^{4}$ Even if its programmatic foundations can be broadly described as right-wing - socially conservative and economically pro-capitalist - the PML has gathered different ideologies over time, which is apparent from the various splits and new parties that emerged from the original independence movement. After the declaration of martial law by Ayub Khan in 1958, the Muslim League was disintegrated, and the new military regime was only supported by its pro-military faction, the Convention Muslim League.

In the 1970 elections that followed Khan's resignation, the Pakistan Muslim League was still unable to unite, and three factions contested the election against each other: the Convention Muslim League, the Council Muslim League, and the Muslim League faction of Abdul Qayyum Khan. In the 1977 election, Pakistan Muslim League parties did not contest as a single block either: they joined the Pakistan National Alliance, a heteroclite coalition of nine Islamic and right-wing parties representing the opposition to Bhutto's government. A new Pakistan Muslim League party was founded in 1985 by Muhammad Khan Junejo with politicians supporting the new government of General Zia-ul-Haq, but it split again in 1988 into two factions, that led by Junejo - the PML-J - and that led by businessman Nawaz Sharif - the PML-N.

The PML-N soon became the dominant party, first by leading the Islamic Democratic Alliance (Islami Jamhoori Ittehad, IJI) in the general elections of 1988 and 1990, and then as an independent party in 1993 and 1997. The party divided yet again in 1997, with the new Pakistan Muslim League (Q) supporting the military coup staged by Pervez Musharraf. The PML-N and PML-Q contested the 2002 and 2008 elections separately, but the PML-N eventually became the dominant Muslim League party again in the elections of 2013 and 2018, receiving some 33 percent and 24 percent of popular votes respectively.

\footnotetext{
${ }^{3}$ The results presented in 1970 correspond to West Pakistan only. We also exclude the 1985 election, which was contested on a non-party basis.

${ }^{4}$ See for instance the autobiography of Ayub Khan (Khan 1970).
} 
The Pakistan Peoples Party was founded in 1967 by Zulfiqar Ali Bhutto in Lahore with a platform promising to provide "roti, kapra and makan" (food, clothing and housing) to everyone (Lodhi 1980). ${ }^{5}$ It became the single biggest party in West Pakistan in 1970, with 37 percent of votes as compared to 21 percent for all Muslim League parties combined. Nevertheless, it failed to win the election in Pakistan as a whole due to the overwhelming success of the Awami Party in East Pakistan. It was only in 1973, following the Bangladesh War of Independence and the resignation of General Yahya Khan, that Bhutto became Prime Minister of the new country. Bhutto was reelected in 1977 as the PPP achieved a landslide victory with 60 percent of votes, notably thanks to widespread vote rigging. From the PPP's apparent domination of the 1960s and 1970s, however, the party system of the 1990s which followed Zia-ul-Haq's death morphed into closer two-party contests, with Muslim League parties altogether receiving 40 percent to 50 percent of votes, as compared to 25 percent to 40 percent for the PPP. The PPP won the elections of 1988, 1993 and 2008, while the PML-N won the elections of 1990, 1997, and 2013.

The Pakistan Tehreek-e-Insaf won the general election of 2018, putting an end to 38 years of alternation between the Muslim League and the PPP in the electoral arena. The PTI was founded in 1996 by former cricket player Imran Khan on a platform of development and fight against corruption. Its 2018 eleven-point agenda included investments in education and healthcare, anticorruption measures, and trade liberalization. Yet, the popularity of the platform of fighting corruption and tacit support of the military establishment behind the scenes were the key distinguishing characteristic of the PTI's rise to power (Shah 2019). The increase of the PTI's vote share from less than 1 percent in 1997 to 32 percent in 2018 coincides with the decline of both the PPP and the PML, revealing the party's success among voters from both traditional right-wing and left-wing constituencies (see Figure 1).

\footnotetext{
${ }^{5}$ Notice that in spite of these redistributive appeals, the PPP was not particularly "socialist". In fact, Bhutto gradually eliminated those believing in socialism from the party's leadership.
} 
At least two other groups of parties are key to understanding the structure of political competition in Pakistan: Islamic parties and the Muttahida Qaumi Movement. Islamic parties have aimed at transforming the country into an Islamic state governed by Sharia law, and they reject both capitalism and communism. Their platform promotes including a greater number of Islamic provisions in the constitution and transforming the criminal system to introduce corporal punishments and eliminate interest in the banking system. Their success in elections since 1970 has fluctuated, in part because they have joined several coalitions with other right-wing or Muslim League parties, which makes it hard to trace their importance as an independent ideological block. In 1970, the Jamaat-e-Islami, the Jamiat Ulema-e-Islam and the Jamiat Ulema-e-Pakistan received as much as 20 percent of votes in West Pakistan, but these parties then joined the IJI in 1977 along with Muslim League factions. Their importance has since then declined, but has not vanished. Islamic parties received renewed success in 2002 by contesting the general election as a single coalition, the Muttahida Majlis-e-Amal (United Council of Action), obtaining 11 percent of votes, which some argue was with the help of Pakistan's military establishment (Bose and Jalal 2017). Likewise, the Muttahida Majlis-e-Amal and other Islamic parties received 9 percent of votes in 2018.

The Muttahida Qaumi Movement (MQM), finally, is a secular party founded in 1984 by Altaf Hussain whose objective was originally to represent the interest of the Muhajirs. The Muhajirs were Urdu-speaking Muslims who emigrated from India to Pakistan following the political division of the subcontinent in 1947, a large majority of which settled in Karachi. The MQM emerged as the third strongest party in the elections of 1990, receiving 5.5 percent of votes, almost all of these coming from urban Sindh, and it has remained strong in most elections since then.

Broadly speaking, Pakistan's party system has therefore historically opposed the left-wing PPP to a changing coalition of right-wing parties more or less supportive of democracy, Islamization, and military intervention, the latter group receiving 35 percent to 55 percent of votes between 1970 and 2013 (see Figure 1; see also appendix Figure A1). The rise of the PTI in 2013 and its victory in 2018 has put an end to this binary structure. It has accelerated the long-run decline of the PPP, who was supported by only 13 percent of voters in 2018 as compared to 31 percent in 2008 . It has 
also come at the expense of the right-wing parties, whose total share of votes fell from 47 percent in 2008 to 34 percent in $2018 .^{6}$

\section{Language, Geography, and Inequality in Pakistan}

How have Pakistani political parties represented different forms of inequalities and social identities in elections, and how have these patterns changed following the decline of the PPP and the rise of the PTI? We provide new insights into these research questions by bringing together a unique dataset of exit polls conducted at the time of general elections by Gallup Pakistan, between 1988 and 2018. Gallup Pakistan surveyed between 3,000 and 5,000 voters coming out of booths to collect information on electoral behaviors, political attitudes, the election campaign, and the sociodemographic characteristics of the electorate. This dataset allows us to study the structure of Pakistani political parties' supporters and the interactions between ethnolinguistic affiliations, regional specificities, and social hierarchies in most general elections since $1970 .^{7}$

Given the importance of ethnicity, language and spatial disparities in Pakistan, let us begin with general figures on the sociodemographic composition of the Pakistani population, which are

6 Aside from these broad divisions, the importance of independent candidates and small parties should not be underestimated: between 1970 and 2018, each of these two groups have received between 2 percent and 20 percent of votes (see appendix Figure A1).

${ }^{7}$ The 1988 election surveyed respondents on their previous voting behaviours in the general elections of 1977 and 1970, so we use this retrospective question to approximate voting patterns for these years. It is important to stress that the consistency and comparatively high sample sizes of these surveys come with important costs in terms of data quality. Women were not surveyed before 2002. No weight was designed by surveyors, so we use linear calibration to make the survey representative in terms of region and election results by party. The 1993 survey did not collect data on rural areas elsewhere than in the Sindh, so we exclude it from the analysis. Also notice that exit polls do not cover turnout by definition, since they survey individuals coming out of voting stations. This is a substantial limitation in a country where electoral turnout has regularly been below 50 percent. 
displayed in Table 1. The country is divided into four provinces: Punjab (54 percent of the population in 2018), Sindh (28 percent), Khyber Pakhtunkhwa (formerly known as the North-West Frontier Province (NWFP), 12 percent), and Baluchistan (6 percent). More than 60 percent of the population still lives in rural areas today. The intersection between rural-urban locations and regional boundaries are very closely linked to linguistic specificities. Punjabi and Saraekee speakers are in large majority located in the Punjab and represented 44 percent and 10 percent of the population in 2018 respectively, with Saraekee speakers being more prevalent in rural areas. The Sindh province is linguistically divided into Sindhi speakers (16 percent of the population), who constitute the majority of the rural population, and Urdu speakers (8 percent of the voting population) who are the descendants of Muhajirs migrants from India and are concentrated in urban areas, especially in Karachi. Pashto speakers amount to 15 percent of the population and over 80 percent of residents of Khyber Pakhtunkhwa. Finally, nearly all Balochi speakers live in Baluchistan, where they represent about half of the population. ${ }^{8}$

The country of Pakistan was created to explicitly welcome the Muslim population of the Indian subcontinent. Between 1988 and 2018, more than 97 percent of voters declared being Muslim in every election. The majority of Pakistani Muslims are Sunni, as compared to an estimated 5 percent to 20 percent who are from the Shia branch of Islam (Kalin and Siddiqui 2014).

Ethnolinguistic and geographic characteristics come with significant income inequalities. According to the exit polls at our disposal, about 70 percent of bottom 50 percent earners lived in rural areas as compared to 53 percent among the top 10 percent. Sindhi and Saraekee speakers are poorer than the rest of the population, representing 39 percent of the bottom 50 percent but only 17 percent of the top decile. Native Urdu and Pashto speakers are slightly richer than other ethnolinguistic groups, while the Punjabi cut across all social classes. ${ }^{9}$ Inequalities between ethnicities are therefore primarily explained by the rural-urban divide. Language and geography

\footnotetext{
${ }^{8}$ See appendix Figure A3 for the complete linguistic composition of voters by region.

${ }^{9}$ See appendix Figures A3, A4 and A5 for the full ethnolinguistic, regional and rural-urban composition of Pakistani income groups in 2018 .
} 
however remain only weakly correlated to social class overall, especially as compared to a number of developing countries such as Thailand (Gethin and Jenmana forthcoming), Brazil (Gethin and Morgan forthcoming), or South Africa (Gethin 2020). Therefore, there is a strong potential in Pakistan for class cleavages crosscutting ethnic identities, or conversely for ethnolinguistic cleavages independent from social class. It is the evolution of these interactions in relation to Pakistan's changing party system that we present in the next sections.

\section{The Changing Structure of Ethnolinguistic Divides}

We start our analysis by focusing on changes in the ethnolinguistic dimension of political divides. Figure 2 plots the share of vote received by the PPP by language between 1970 and $2018 .{ }^{10}$ In all general elections, the core voting base of the left-wing party has lied among Sindhi speakers. In the first direct election of 1970, as much as 95 percent of Sindhis voted for Zulfiqar Ali Bhuto's Pakistan Peoples Party compared to less than 40 percent of other ethnolinguistic groups. This support was likely rooted in the fact that Bhutto, as a large landowner from Larkana in the center of Sindh, had the resources for patronage politics in rural constituencies, as well as ethnic legitimacy, which allowed him to galvanize support in the province. ${ }^{11}$ In the past forty years, the decline of the PPP has not been concentrated in a specific region or language: it has happened among all groups, so that the gap between Sindhi speakers and other groups has remained very stable. As Figure 3 shows, furthermore, the massive relative support received by the PPP among the Sindhis cannot be accounted for by differences in income or education levels across ethnic groups. Both before and after accounting for the independent effects of education, income, ruralurban location, maslak, age, and gender, Sindhi speakers have always been more likely to support the PPP by 30 to 60 percentage points.

\footnotetext{
${ }^{10}$ We exclude Baloch in our analyses of language given that they represent less than 4 percent of the population, leading to very low sample sizes and unreliable estimates.

${ }^{11}$ S. Das, Kashmir and Sindh: Nation-building, ethnicity and regional politics in South Asia (Anthem Press, 2001).
} 
The transition from the overwhelming victory of Bhutto in 1977 to the two-party system of the 1990s and the rise of the PTI in 2013 and 2018 did however mark a progressive ethnicisation of the Peoples Party's supporters. In the 1970s and 1980s, the PPP was able to win elections by receiving significant support from non-Sindhi ethnicities, and in particular from the populated Punjab province. This was not the case in 2018 anymore: the PPP only obtained a majority among Sindhis as compared to less than 10 percent of votes among all other ethnic groups, which explains why its nationwide vote share did not exceed 13 percent. This transition from a dominant party with broad support to an exclusive party relying on a single minority group is remarkably similar to the decline in the Indian National Congress and its shift towards Muslims and lower castes in the past seventy years of Indian democracy - even though caste and religion, rather than ethnicity, have played a greater role in the latter transformation (Banerjee, Gethin and Piketty 2018). It reflects how dominant movements are always forced to rely on unstable coalitions, whose erosion comes with a necessary focus on increasingly specific social identities. This comparison should however not be exaggerated in the case of Pakistan: the decline of the PPP was the outcome of a chaotic process of democratic contests, repression, and military intervention, rather than the sole result of dissatisfaction with a single ruling party.

The evolution of Muslim League parties and their coalitions reveals comparable transitions. PML parties have always received greater support in the Punjab (see Figure 3), yet they always had to rely on support from other regions to win elections. This broader electorate was partially the byproduct of the PML's success in joining Islamic parties against the PPP (even if the latter has also built coalitions with Islamic parties in the past, such as the Jamiat Ulema-e-Islam): in the elections of 1977, the PNA obtained more than 35 percent of votes among Pashto, Punjabi, Saraekee and native Urdu speakers. In the 1990s, the electorate of the PML-N was also broader than that of the PPP, even if Nawaz Sharif's party did receive significantly greater votes in the Punjab. The ascent of the PTI in 2013 and 2018 further restricted the PML's electorate to Punjabis, Saraekee and native Urdu speakers.

Figure 5 plots the difference between the share of Punjabi speakers voting for right-wing coalitions and the share of other ethnolinguistic groups voting for right-wing coalitions between 1970 and 2018. The gap between Punjabis and other groups rose from about 0-5 percentage points in the 
1970 s to $20-30$ percentage points in the 1990 s and has remained stable since then. This increase mirrors the progressive fragmentation of the right wing in Pakistan, from the PNA coalition in 1977 and the IJI coalition in 1988 to 1990 to the PML-N running as a single party from 1993 onwards. Just as in the case of the PPP, the premium received by right-wing parties in the Punjab is robust to controlling for the effect of other sociodemographic variables.

How has the emergence of the PTI affected the political representation of ethnolinguistic divides in Pakistan? Table 2 shows the share of votes received by parties or groups of parties by language in the 2018 general election which led to the victory of Imran Khan. Two main conclusions can be drawn from these figures. Firstly, the structure of Pakistan's party system into five broad groups of parties is highly correlated to linguistic divisions. The PPP is mainly supported by Sindhis, the PML by Punjabi and Saraekee speakers, the PTI by Pashtuns, Islamic parties by Pashtuns and Baloch, and the MQM by Mujahirs. The majority of Punjabi and Saraekee speakers support either the PML or the PTI. Secondly, the PTI stands out as the only party receiving substantial vote shares among all ethnicities. More than half of Pashto speakers voted for Khan in 2018, which can be explained both by the leader's Pashtun origin as well as the party's historical success in the Pashtun region. The PTI however also received more than 30 percent of votes among Punjabi and Saraekee speakers, 21 percent among Sindhis, and 15 percent among the Baloch.

The long-run evolution of Pakistan's party system therefore reveals two parallel dynamics. On the one hand, traditional parties have become increasingly ethnic-based, with the once dominant PPP receiving nearly all its support from Sindhis in 2018, while the voting base of the PML-N has become increasingly restricted to the Punjab region. On the other hand, the PTI has emerged as a new, broad-based party capable of overcoming local ethnic affiliations and winning the 2018 election thanks to significant support coming from all provinces of Pakistan. This opens up a new question: if language is only weakly correlated to voting for the PTI, on what other form of coalition is the ruling party relying? We explore this question in the next section by focusing on the changing roles of education and income in accounting for electoral behaviors in Pakistan.

\section{The Political Unification of the Pakistani Elite and the Rise of the PTI}


Independently from ethno-regional affiliations, economic divides have been a key dimension of political conflicts in Pakistan since independence. Originally, the PPP was formed by an alliance of socialists favoring labor unions and poor farmers. In 1972, Bhutto announced the nationalization of key industries, engaged in a land reform redistributing acres to landless peasants, and nationalized health and education. In the 1970s, party politics in Pakistan therefore had a clear leftright dimension.

As alluded to earlier, the PPP was therefore formed on the socialist promise of food, clothing and housing for every citizen. It famously was successful in West Pakistan in the 1970 elections where the party pitied its socialist "workers" against large land-owning and feudal politicians - even if there were many of the latter in the party's ranks, and Bhutto himself was a feudal lord. Following the end of General Zia-ul-Haq's martial law, however, Benazir Bhutto's government that came to power was relatively more market oriented and did not re-nationalize the industries but did start a large transfer program, the Benazir Income Support Program. Similarly, the PML-N evolved from being fervently backed by Islamic right-wing alliances and the military establishment to having its own centre-right policies and agenda, even exerting some degree of independence from the military that many argue led to its eventual downfall (Bose and Jalal 2017).

The PTI, however, may have seen the largest swing in both its ideology as well as electoral success from 2013 to 2018. With finishing third, after the PPP and PML-N in 2013, to finishing first in 2018 elections. PTI support was largely limited to urban middle class until 2013 but the party changed its anti-status quo, anti-military establishment and reformist agenda to broadening of its support base to Islamists, security establishment and gaining support of large industrialists and feudal politicians that dominate rural (South) Punjab. Therefore, PTI was able to consolidate its success in 2013 by broadening its political support to include local politicians whose constituent rural population vote along ethnolinguistic lines. This was facilitated by Pakistan's strong military establishment that encouraged these 'winning horses' to come in the PTI's fold. That being said, the PTI did manage to keep the support base it had in 2013 even as it pandered to Islamic voters using religious rhetoric such as support of Blasphemy law in its election campaigns (Nelson 2015; Dorsey 2018). In this sense, only the PPP in 1970 elections was able to win the rural areas on a popular agenda and promise of reform while earlier PML-N and more recently PTI was only able 
to win the elections through a successful coalition with large landowners, industrial elites and military establishment that dominate electoral politics in rural Pakistan (Shah 2019).

Figure 6 shows the share of votes received by the PPP by income decile between 1970 and 2018 . Low-income voters have been more likely to support the PPP than richer individuals in all elections since 1970. In 1977, for instance, 75 percent of the poorest 10 percent of Pakistani voters voted for Bhutto compared to 49 percent of top 10 percent earners. The same differences have persisted since then, so that the decline of the PPP has come from all income groups in similar proportions. As we show in the appendix, comparable patterns are visible when looking at education: illiterates have always been much more likely to support the PPP than university graduates, and this fact has remained highly persistent across time.

We highlighted at the beginning of this paper the persistence of strong differences in standards of living between ethnolinguistic groups, with Sindhi and Saraekee speakers being significantly poorer than other Pakistani residents, in large part due to the rural-urban gap. Was the PPP ever supported by the poor, or can its success among low-income earners entirely be explained by the lower income levels of Sindhis? Figure 7 shows the difference between the share of top 10 percent earners and the share of bottom 90\% earners voting for the PPP, before and after controlling for other sociodemographic characteristics of the electorate. Between 1970 and 2018, high-income earners have been less likely to support for the PPP by about 10 percentage points on average. After controlling for region and language, the difference gets closer to zero, but remains negative at about 5 percentage points on average. This shows that the lower income levels of Sindhis does partially explain the success of the PPP among the poor, but not entirely: low-income earners from other regions, and in particular in the Punjab, were key to explaining the party's electoral victories. Another interesting result is the complete disappearance of any independent income effect in 2013 and 2018, which reflects the restriction of the PPP's voting base among Sindhis only.

Results for education show comparable evolutions overall, even if higher educated voters seem to have been less likely to support the PPP only in 1970 and 1977, with no clear pattern since then (see appendix Figure A17). In any case, social class or economic status do seem to only have played a role of secondary importance in determining left-right divides in Pakistan. As we show 
in the appendix, support for PML parties and right-wing coalitions show even more fluctuating patterns, with no clear persisting income or education gradient. Similarly, Islamic parties have historically been slightly more supported by higher-income and higher-educated voters, but this is almost entirely explained by their relatively high vote shares among the Urdu-speaking population and Pashtuns. ${ }^{12}$

How has the recent success of the PTI at the center of the political spectrum affected the relative importance of ethnicity and social class in structuring political cleavages in Pakistan? Figure 9 shows the relative support received by Imran Khan's party in 2013 and 2018, before and after controlling for the independent effects of other sociodemographic variables. Both higher-income and higher-educated voters have been significantly more likely to vote for the PTI in the last two Pakistani elections. In 2018, for instance, 24 percent of illiterate voters supported Imran Khan, compared to 42 percent of tertiary-educated individuals, so that top 10 percent educated voters have been more likely to support Khan by 11 percentage points. ${ }^{13}$ Moreover, the effect of income is only moderately reduced when controlling for region, language and other variables, while the effect of education remains approximately unchanged. This shows that middle and upper class voters, and especially the higher educated, have been more likely to vote for the PTI independently from their regional or ethnolinguistic affiliations.

The recent success of the PTI has therefore announced a historical change in the structure of political cleavages in Pakistan. The party system of the 1970s and 1980s mainly opposed lowincome PPP voters located in the Sindh and other rural areas to a broad coalition of right-wing

\footnotetext{
12 The results provided in this section should be interpreted with caution given the low quality of the income and education data at our disposal. In the appendix, we provide figures showing vote shares by income and education for all groups of parties (see Figures A10 to A19), as well as tables showing the results of regression models assessing the determinants of support for the PPP, the PML / IJI / PNA, Islamic parties, and the PTI (see Tables A3 to A6). Many coefficients are only weakly significant given low sample sizes and probably measurement error. Income and education are strongly correlated, so that one variable is often significant while the other is not, and conversely.

${ }^{13}$ See appendix Figures A12, A15, and A19 on the vote share received by the PTI by income and education level.
} 
parties with diverse ideologies and sociological foundations. The decline of the PPP has come by with the fragmentation of class affiliations, the ethnicisation of traditional parties' constituencies, and the unification by the PTI of a new elite cutting across linguistic identities.

\section{Islamization and the Politics of Minorities}

The country of Pakistan was created to explicitly welcome the Muslim population of the Indian subcontinent. Between 1988 and 2018, the exit polls at our disposal show that more than 97 percent of voters declared being Muslim in every election (see Table 1). The majority of Pakistani Muslims declared being Sunni, as compared to an estimated 5 percent to 20 percent who are from the Shia branch of Islam. The true share of Shia Muslims in the Pakistani population however remains very difficult to estimate given Pakistan's contemporary history of Islamization and repression of religious minorities, which implies that underreporting of true Shia identity may have been significant until today, and may have been more or less pronounced depending on local or national contextual factors.

This repression was notably visible during the rule of General Zia-ul-Haq. General Zia, soon after coming to power through the military coup of 1977 , consolidated his power with a wave of Islamization policies. Building on the coalition of anti-Bhutto Islamists he set out a series of policies that adversely impacted the minorities. A key casualty was the Shia population in Pakistan, who differed not just in religious denomination but also along ethnic and linguistic lines. The Shia community organized large protests against General Zia's interpretation and implementation of (Sunni) Islam on them. Following mass protests, General Zia took back his proposed uniform implementation of Zakat (charity) on every Muslim citizen in Pakistan to implementing it only on Sunni Muslims. General Zia, however, tried to reduce the influence of Shia political and militant organizations by fanning the flames of extremism and giving Sunni extremist organizations impunity to persecute the Shia population (Ispahani 2013). Perhaps the most lasting symbol of Zia's legacy is Pakistan's infamous induction of section 295C in Pakistan constitution, that stipulated the death penalty for blasphemy. No person has ever been convicted and executed on this law, but it has given rise to a large number of cases against minorities, including acts of vigilantism and violence against Christian and Hindu minorities. 
Figure 9 shows the share of votes received by the PPP by religious affiliation between 1970 and 2018 (votes among non-Muslims are only shown after 2002 given too low sample sizes in previous polls). The PPP has always received substantially greater support among religious minorities than among the majority Sunni voting population. In 1970, for instance, 51 percent of Shia voted for Zulfiqar Ali Bhutto in West Pakistan, compared to 36 percent of Sunnis. Bias towards the PPP has been even stronger among non-Muslims: in the 2018 general election, the PPP was backed by an all-time low 11 percent of Sunnis, but by 29 percent of Shia and as much as 46 percent of nonMuslims. This result is consistent with the PPP's historical secular socialist ideology as compared to the more conservative and traditional policies proposed and implemented by the Pakistan Muslim League parties and by military regimes.

As Figure 10 shows, this result remains significant after controlling for language, region, ruralurban locations and other variables available from the exit polls: in 2018, Shias and non-Muslims were more likely to support the PPP by 24 percentage points before controls, and 14 percent after controls. We show in the appendix, however, that votes for the PTI among Shia Muslims have significantly increased between 2013 and 2018, so that they have become as likely to vote for Imran Khan as Sunnis. This may be due to the complete loss of political space of the PPP to the PTI in South Punjab, where large fraction of Shia voters reside historically (Zahab 2002). The vote of minorities, alongside ethnolinguistic and class divides, therefore appears to be a third independent dimension of Pakistani electoral politics which can be clearly identified. This persisting and strong support for left-wing parties among historically disadvantaged minorities is comparable to that found in many other democracies, from the Afro-American vote in the United States (Piketty 2018) to the Muslim vote in India (Banerjee, Gethin and Piketty 2018).

\section{The Effect of Zia's Islamization Policies}

How has Pakistan's party system transitioned from the electoral domination of the mass-based socialist PPP of the 1970s to the success of the military-backed PTI supported by intellectual and economic elites in 2018? We conclude this paper by emphasizing the crucial role of General Ziaul-Haq's policies in explaining this transformation. Zia-ul-Haq was the chief of Pakistan's military 
who became the sixth President of Pakistan, after his rise to power through a military coup. Ruling from 1978 to 1988, until his death in a plane crash, he remains Pakistan's longest serving President and have presided over a number of key reforms that many believe have had far reaching consequences on State and society in Pakistan (Tariq 2011; Burki 2016).

There are two key policy changes that are attributed to General Zia. The first one is the decentralization reform of 1979 who was implemented through the promulgation of the local government ordinance (LGOs). The military regime of General Zia used the strategy of "divide and rule" by creating a new class of "collaborative" local political elites that were beholden to the military regime (Jalal 1995). This political elite consisted of religious leaders associated with holy shrines, Islamic and right-wing politicians as well as disgruntled members of the Pakistan Peoples Party. The local government system introduced by Zia enabled him to consolidate his power since he free-rode on the local legitimacy of religious leaders and local political leaders.

Second, a critical policy change attributed to General Zia's regime is the Islamization policies known under the broad "Nizam-e-Mustafa" slogan (The System of Prophet Muhammad). This took place following his 1978 address to the nation where ambitious "reforms" in Pakistan's institutions took place. These included the constitution of a separate judicial branch, the Shariat Courts that were to judge legal cases under Islamic doctrine. Likewise, new criminal offenses were added in Pakistani penal courts with adultery, fornication and blasphemy becoming criminal offenses punishable under Pakistani law. Furthermore, the banking system forbade the payment of interest to lenders and instead substituted it with profit and loss payments (Kepel 2002).

There was also an effort to "cleanse" the school textbooks and libraries from "un-Islamic material" and a concerted effort to change the school curriculum. Arabic was introduced as a second language in schools. There were also other minor changes such as schools, offices and factories being required to provide praying space as well as time allotted for conservative religious scholars at national television. Overall, General Zia's policies aimed to build a political coalition of Islamists and conservative politicians that supported him and his conservative policies and tried to create a population receptive to these ideas through use of propaganda and repression of dissent. 
Therefore, the active indoctrination of a whole generation on Islamic propaganda and promotion of right-wing ideas and policies may give rise to a conservative and educated political class adverse to left-wing ideals. It may account for the decline of PPP we see in our data and explain the consolidation of right-wing political views we see in other available surveys (Siddiqa 2010).

\section{References}

A. Banerjee, A. Gethin, and T. Piketty, "Growing Cleavages in India? Evidence from the Changing Structure of Electorates, 1962-2014" (WID.world Working Paper, 2018).

A. D. Behera, "Pakistan General Elections 2018: Clear Signs of a Guided Democracy," International Studies 55, no. 3 (2018): 238-252

S. Bose and A. Jalal, Modern South Asia: History, Culture, Political Economy (Routledge, 2017).

S. K. Burki, “The Politics of Misogyny: General Zia-ul-Haq's Islamization of Pakistan's Legal System," Contemporary justice review 19, no. 1 (2016): 103-119

J. M. Dorsey, “Pakistan and its Militants: Who is Mainstreaming Whom?" (SSRN 3263124, 2018).

A. Gethin, "Extreme Inequality and the Structure of Political Cleavages in South Africa, 19942019” (WID.world Working Paper 2020/13, 2020).

A. Gethin and T. Jenmana, "Democratization and the construction of class cleavages in Indonesia, Malaysia, Thailand, and the Philippines, 1992-2019” (forthcoming working paper).

A. Gethin and M. Morgan, "Democracy and the politicization of inequality in Brazil, 1989-2018" (forthcoming working paper).

C. Jaffrelot, The Pakistan Paradox: Instability and Resilience (Hurst Publishers, 2015).

F. Ispahani, “Cleansing Pakistan of Minorities" (Hudson Institute 31, 2013).

A. Jalal, Democracy and Authoritarianism in South Asia: A Comparative and Historical perspective, volume 1 (Cambridge University Press, 1995).

M. Kalin and N. Siddiqui, Religious Authority and the Promotion of Sectarian Tolerance in Pakistan (US Institute of Peace, 2014). 
G. Kepel, Jihad: The Trail of Political Islam (Harvard University Press, 2002).

M. A. Khan, "Friends Not Masters. A Political Autobiography," VRÜ Verfassung und Recht in Übersee 1, no. 3 (1970): 368-369

M. Lodhi, "Bhutto, the Pakistan Peoples Party and Political Development in Pakistan: 1967-1977" (PhD dissertation, The London School of Economics and Political Science, 1980)

S. Mehmood and A. Seror, "Religion, Politics, and Judicial Independence: Theory and Evidence" (AMSE Working Paper, 2020).

M. J. Nelson, "Islamist Politics in South Asia after the Arab Spring: Parties and their Proxies Working with - and against - the State" (Washington DC Brookings Institution, 2015)

T. Piketty, "Brahmin Left vs Merchant Right: Rising Inequality \& the Changing Structure of Political Conflict (Evidence from France, Britain and the US, 1948-2017)" (WID.world Working Paper Series 2018/7, 2018).

A. Shah, "Pakistan: Voting under Military Tutelage," Journal of Democracy 30, no. 1 (2019): 128142.

A. Shah, "Pakistan in 2018: Theft of an Election," Asian Survey 59, no. 1 (2019): 98-107

A. Siddiqa, "Red Hot Chilli Peppers Islam - is the Youth in Elite Universities in Pakistan Radical?" (Paper for 'Foreign-Security Policy Series' of Heinrich Boll Stiftung, 2010).

M. M. Tariq, "The Rise and Impact of Islamic Fundamentalism in Pakistan after the Soviet Invasion in Afghanistan with Special Reference to KPK and Baluchistan," Balochistan Review 24 (2011).

S. O. Wolf, "44d 2020-False start for Democracy in Pakistan" (SADF, 2020).

M. Abou Zahab, "Sectarianism as a Substitute Identity: Sunnis and Shias in Central and South Punjab," In Pakistan: The Contours of State and Society, edited by S. Mumtaz, J. L. Racine, and I. A. Ali (Oxford University Press, 2002). 


\section{Major Ethnicities in Pakistan}

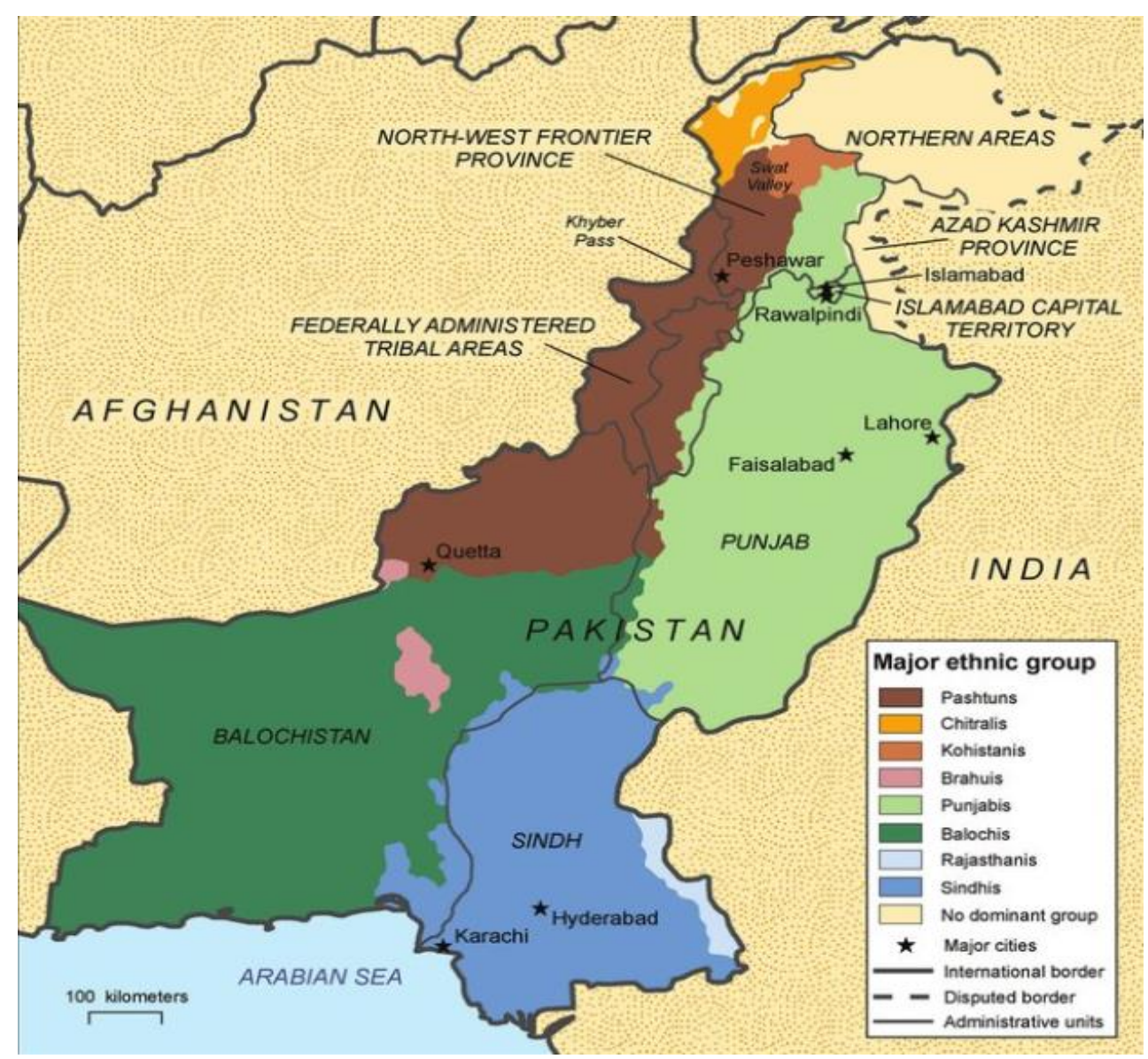

Source: D. Mustafa and K. E. Brown, "The Taliban, public space, and terror in Pakistan," Eurasian Geography and Economics 51, no. 4 (2010): 496-512. Note: this map provides a simple description of the spatial distribution of major ethnic groups in Pakistan. 
Figure 1 - Election results in Pakistan, 1970-2018

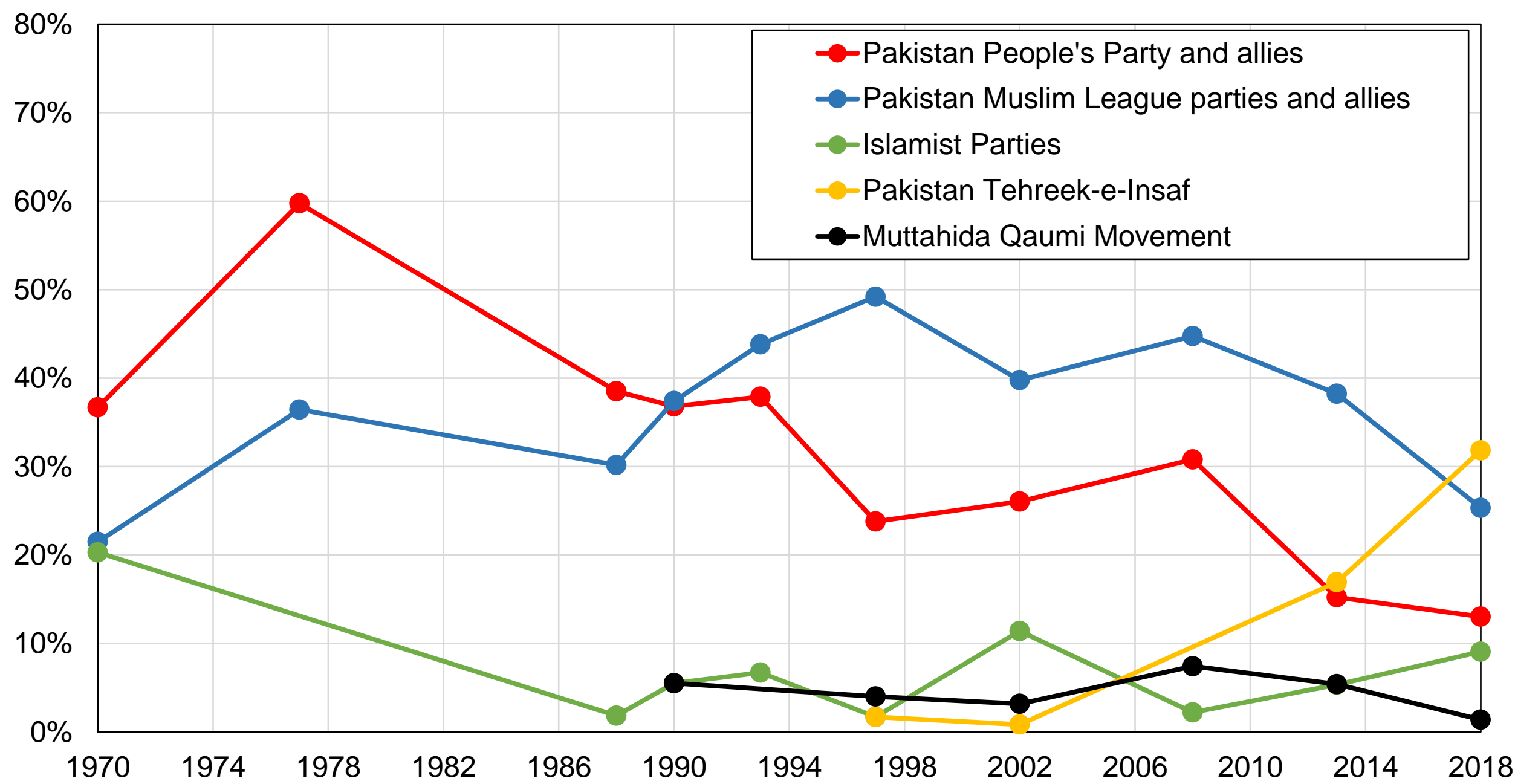

Source: authors' computations using official election results.

Note: the figure shows the share of votes received by selected Pakistani political parties in general elections between 1970 and 2018. Figures for 1970 correspond to West Pakistan only. 
Figure 2 - Vote for the PPP by language, 1970-2018

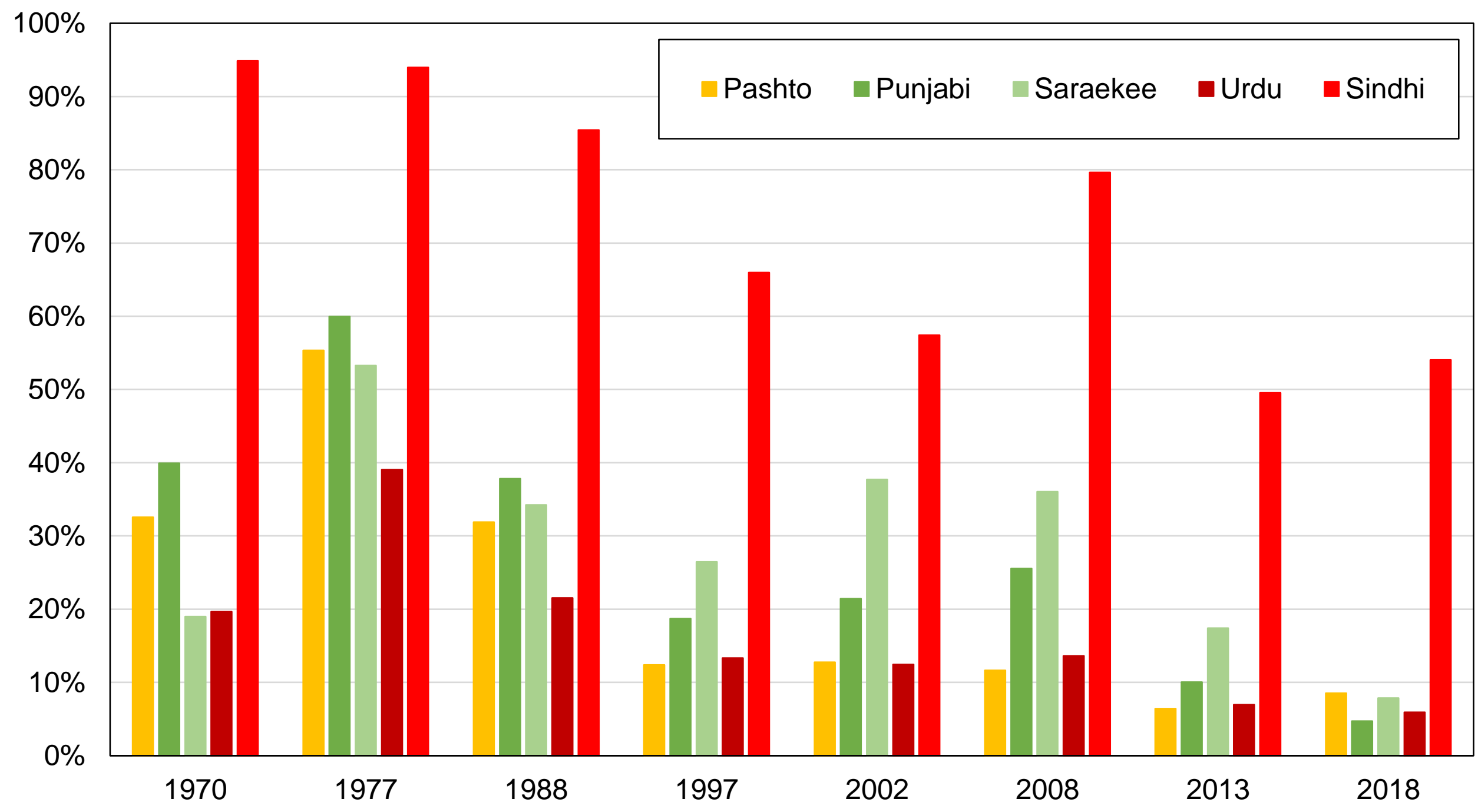

Source: authors' computations using Pakistani polls.

Note: the figure shows the share of votes received by the PPP by linguistic group. 
Figure 3 - Vote for PPP among Sindhi speakers, 1970-2018

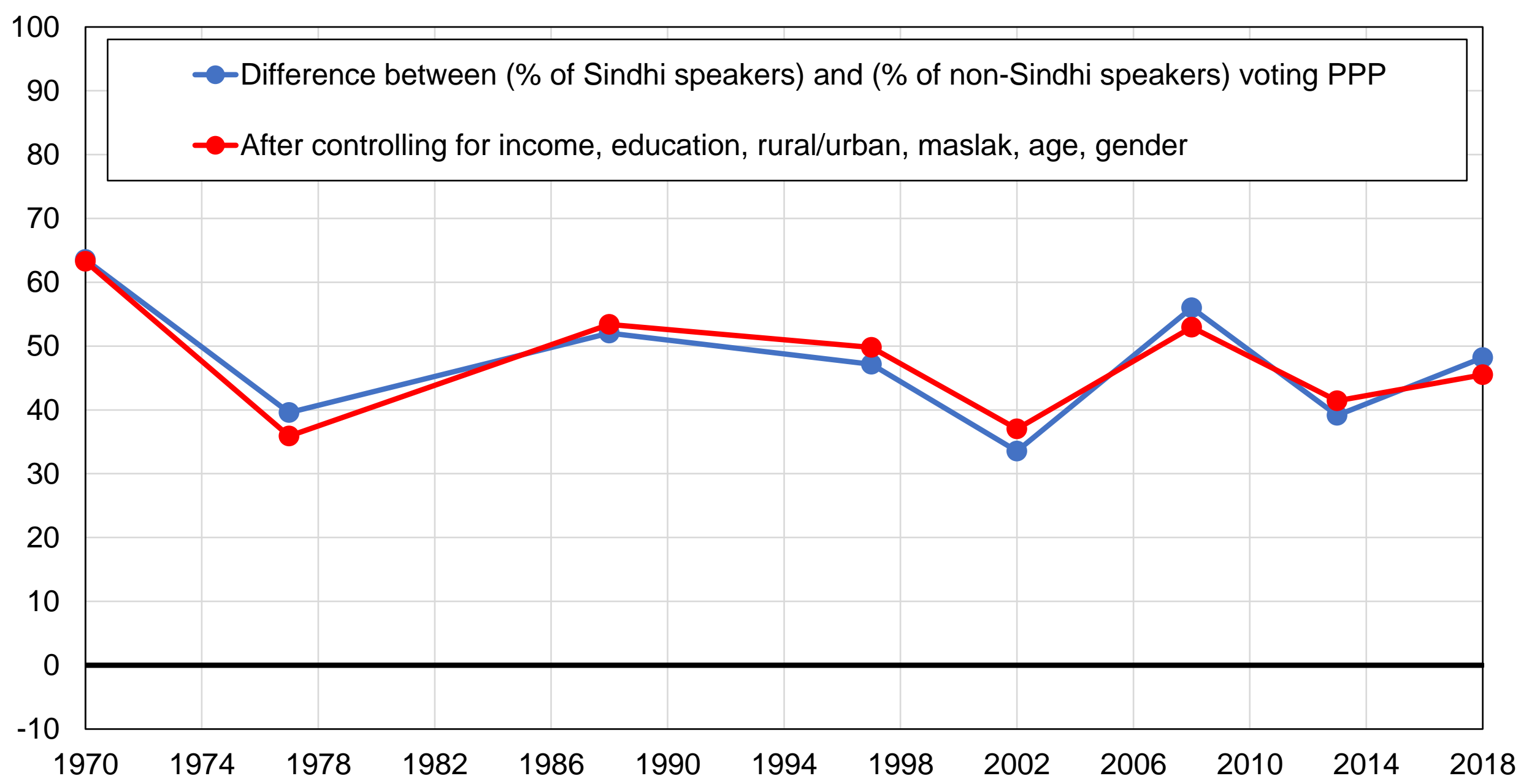

Source: authors' computations using Pakistani polls.

Note: the figure shows the difference between the share of Sindhi speakers supporting the PPP and the share of other voters supporting the PPP, before and after controlling for other variables. 
Figure 4 - Vote for PML / IJI / PNA by language, 1970-2018

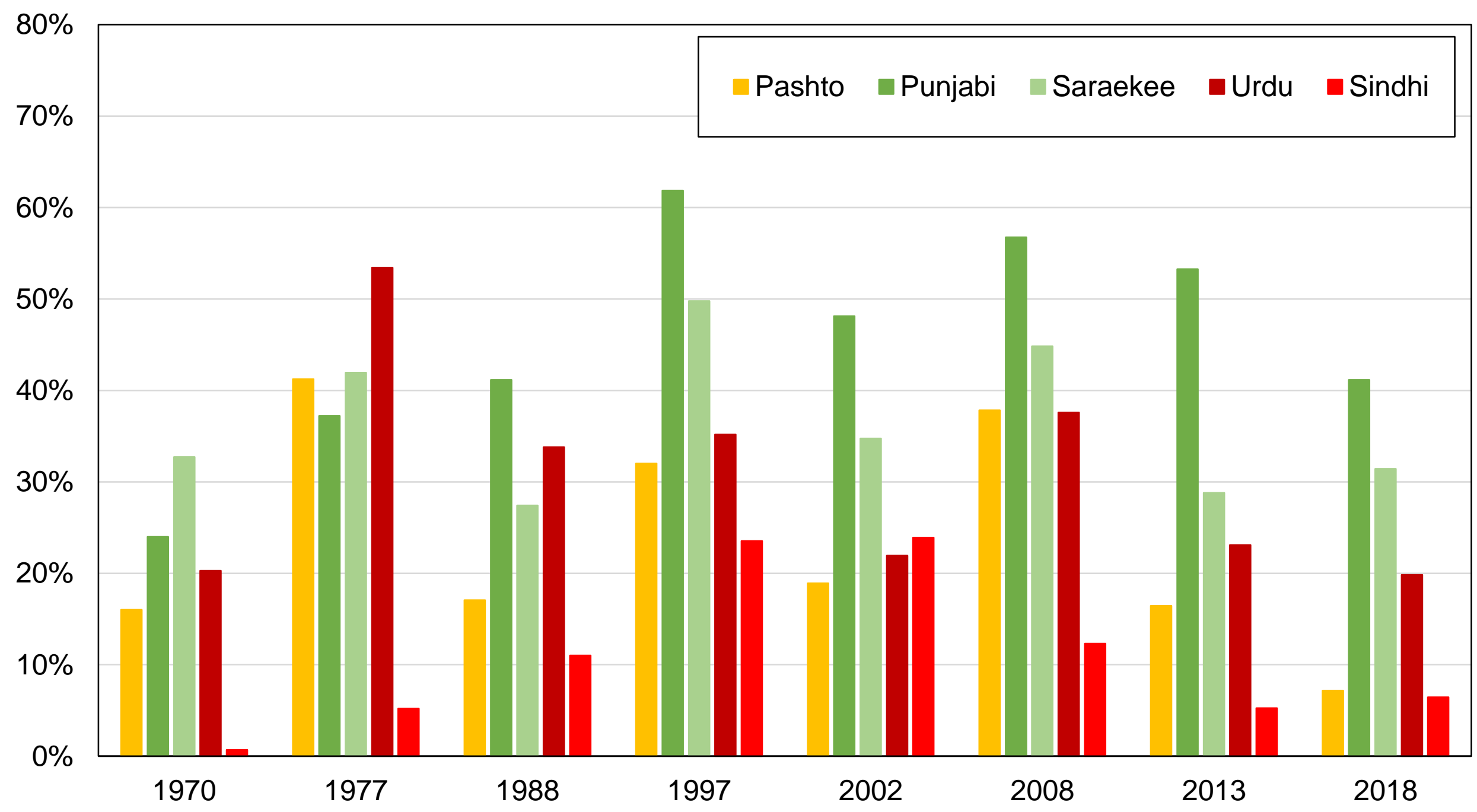

Source: authors' computations using Pakistani polls.

Note: the figure shows the share of votes received by the PML / IJI / PNA by linguistic group. 
Figure 5 - Vote for PML / IJI / PNA among Punjabi speakers, 1970-2018

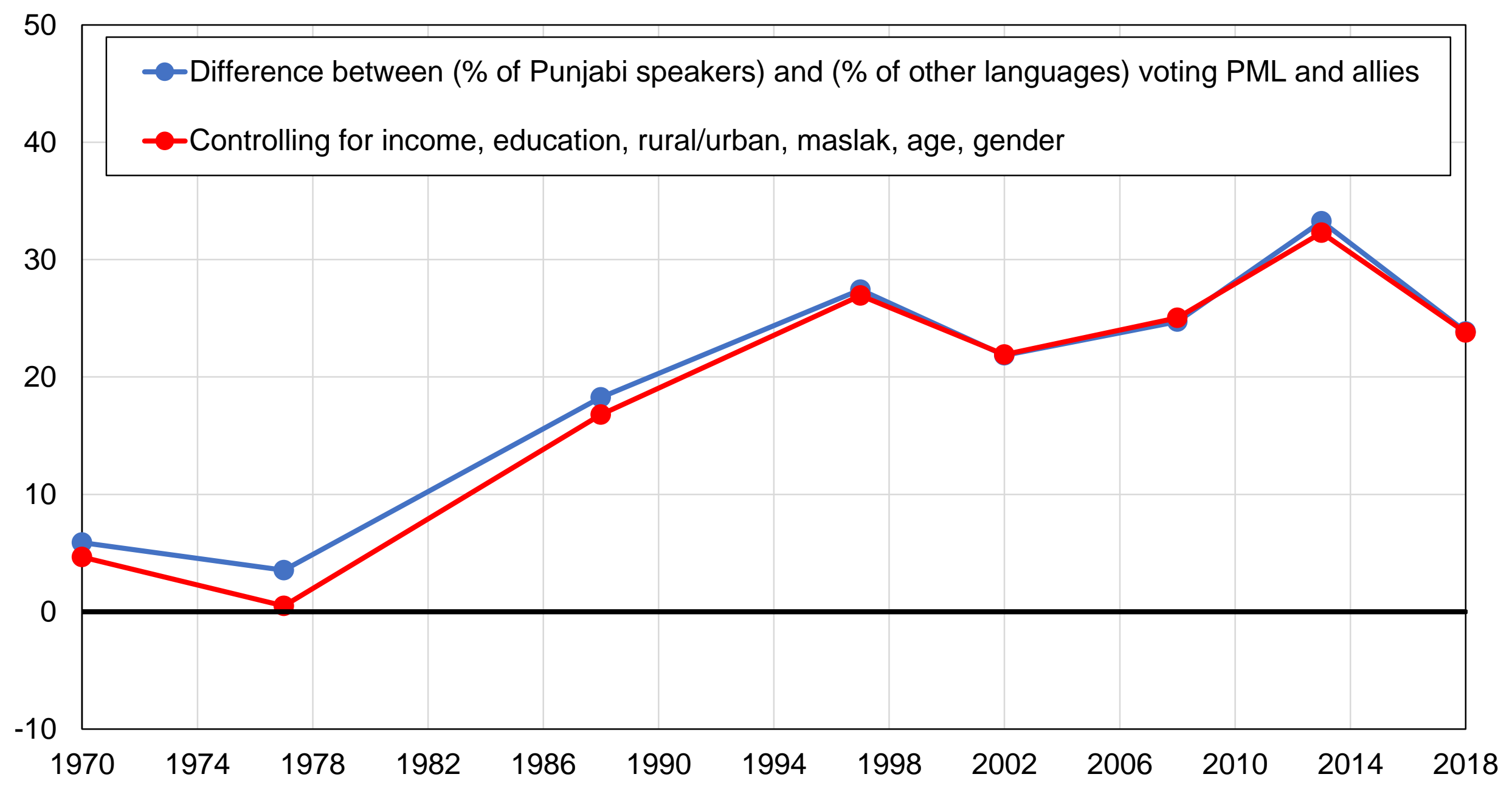

Source: authors' computations using Pakistani polls.

Note: the figure shows the difference between the share of Sindhi speakers supporting the PML / IJI / PNA and the share of other voters supporting the PML / IJI / PNA, before and after controlling for other variables. 
Figure 6 - Vote for PPP by income decile, 1970-2018

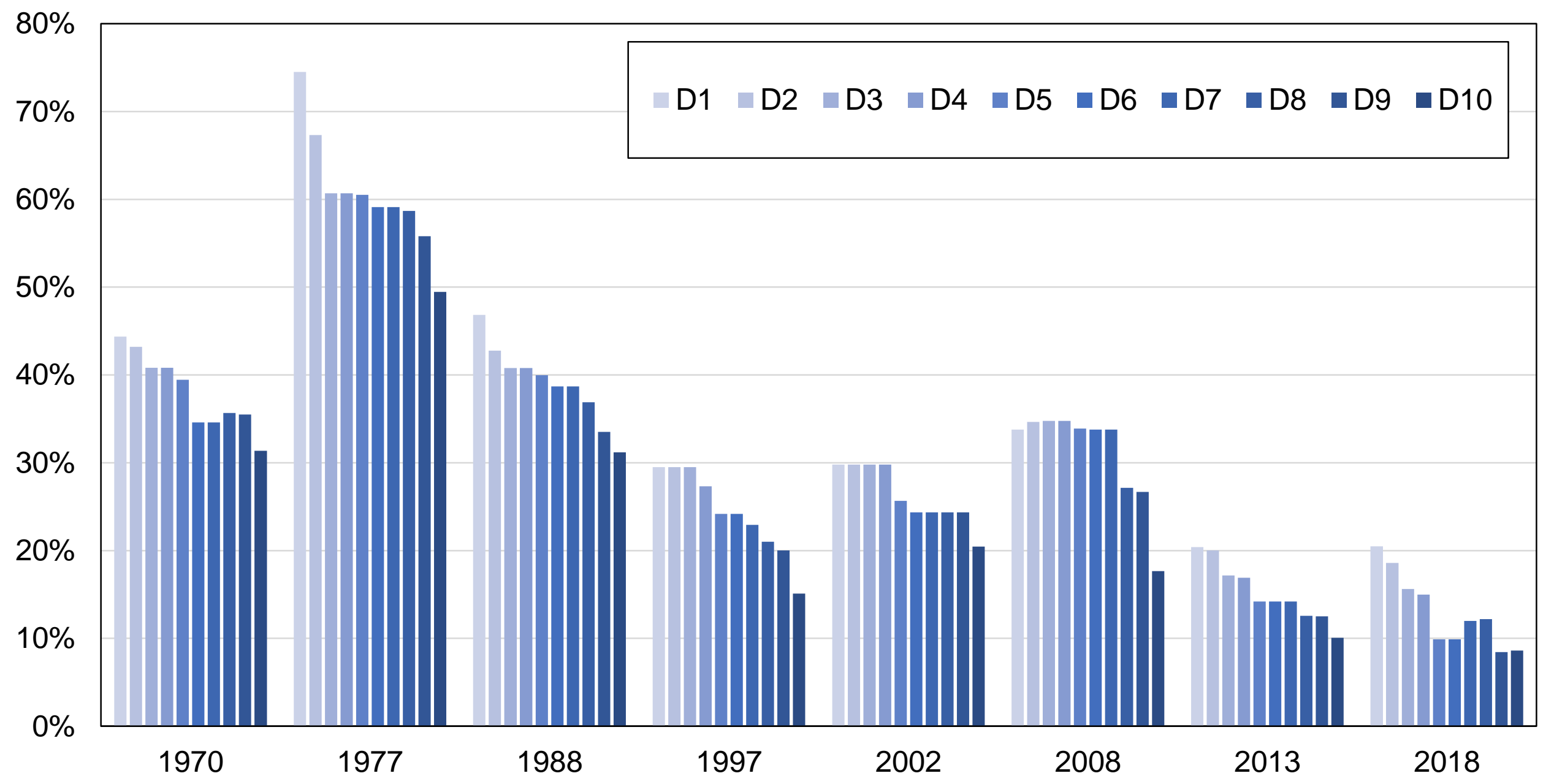

Source: author's computations using Pakistani polls.

Note: the figure shows the share of voters supporting the PPP in general elections among the poorest $50 \%$ of voters, the next $40 \%$, and the top $10 \%$ of earners. 
Figure 7 - Vote for the PPP among top income earners, 1970-2018

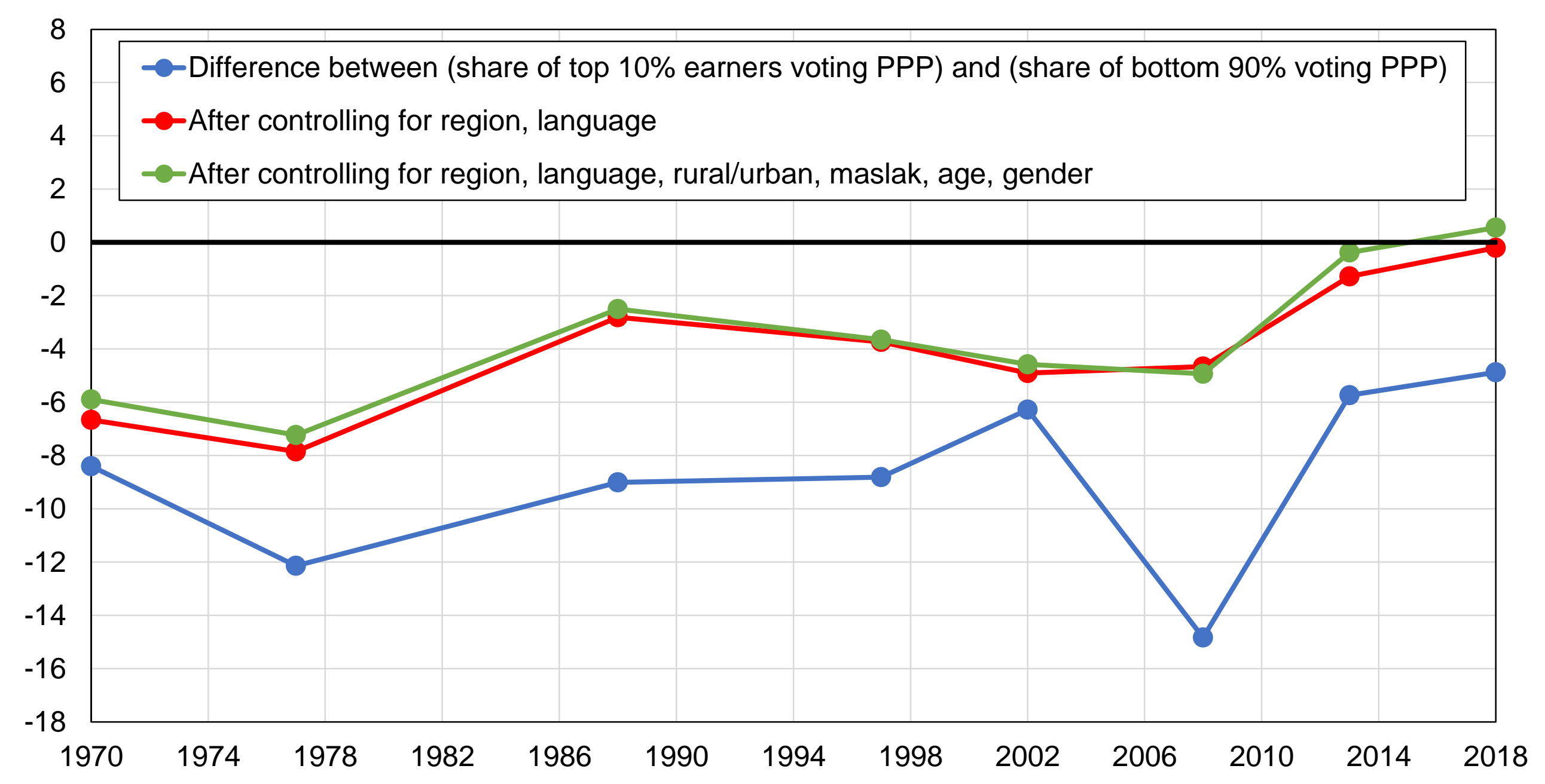

Source: authors' computations using Pakistani polls.

Note: the figure shows the difference between the share of top $10 \%$ earners voting PPP and the share of bottom $90 \%$ earners voting PPP, before and after controlling for other variables. 


\section{Figure 8 - Vote for PTI among top income earners and higher educated voters, 2013-2018}

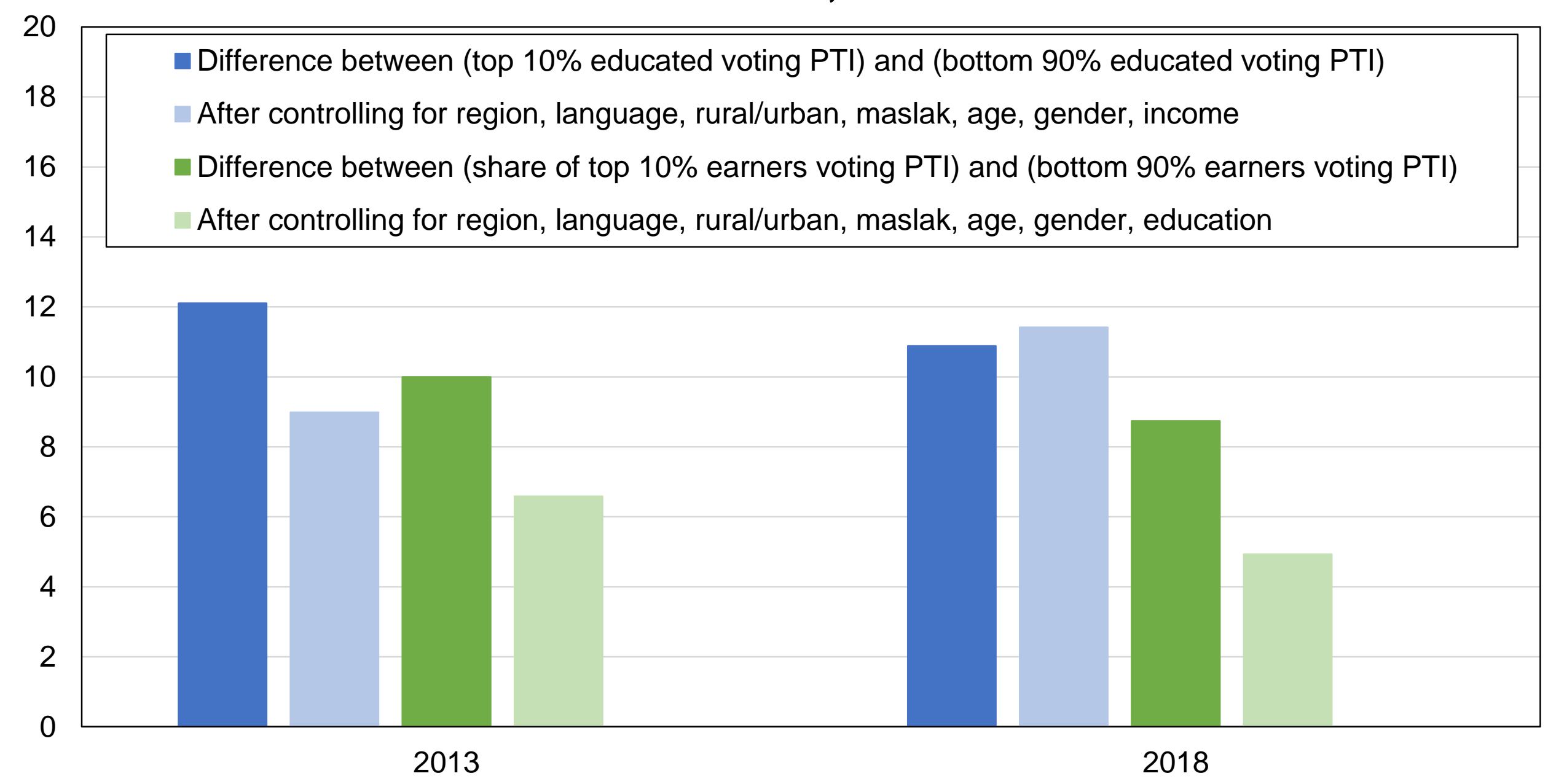

Source: authors' computations using Pakistani polls.

Note: the figure shows the relative support received by the PTI among top income and top educated voters in the general elections of 2013 and 2018, before and after controlling for other variables. 
Figure 9 - Vote for PPP by religious affiliation, 1970-2018

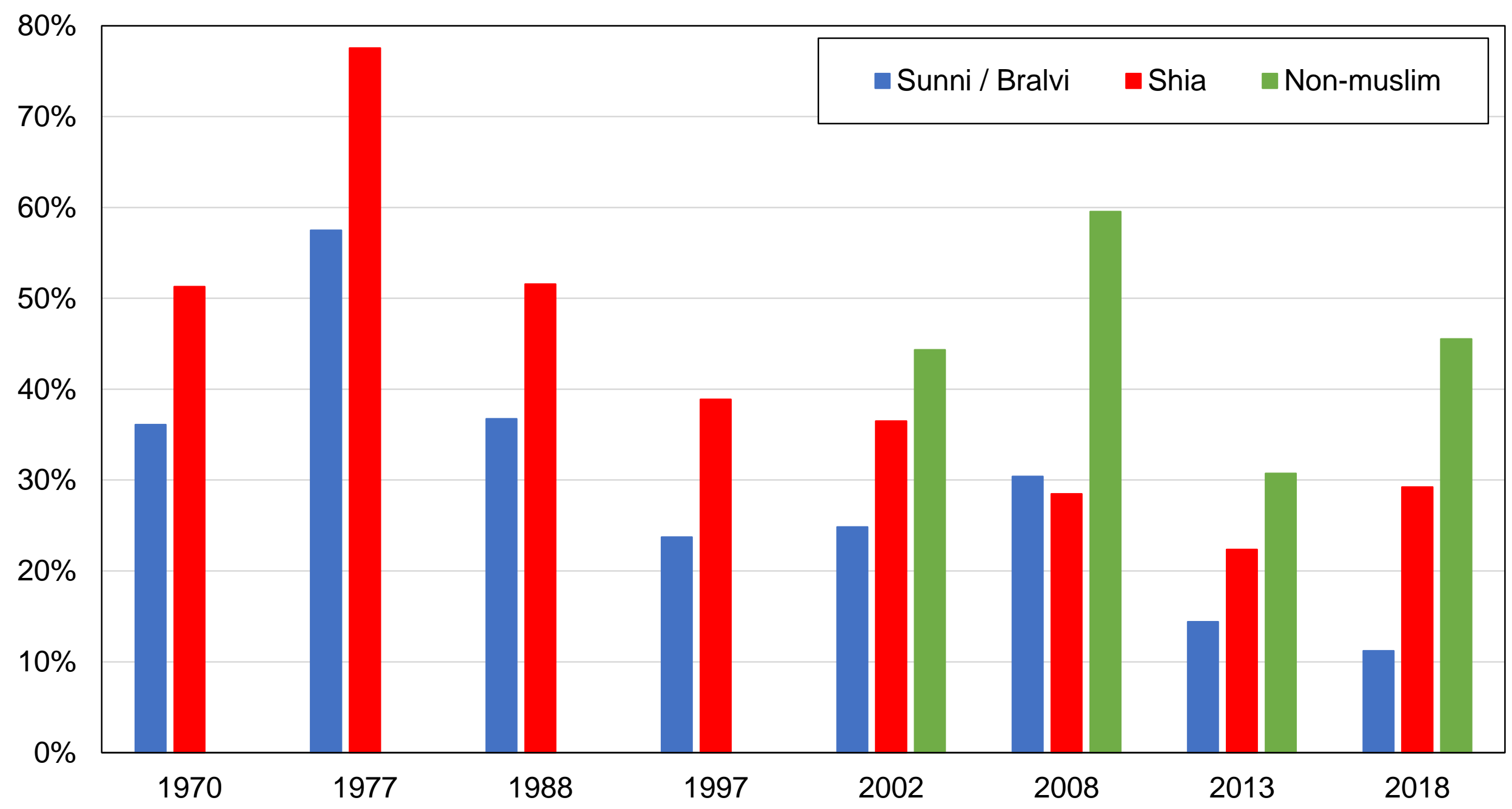

Source: author's computations using Pakistani polls.

Note: the figure shows the share of voters supporting the PPP in general elections by religious affiliation. 
Figure 10 - Vote for PPP among religious minorities, 1970-2018

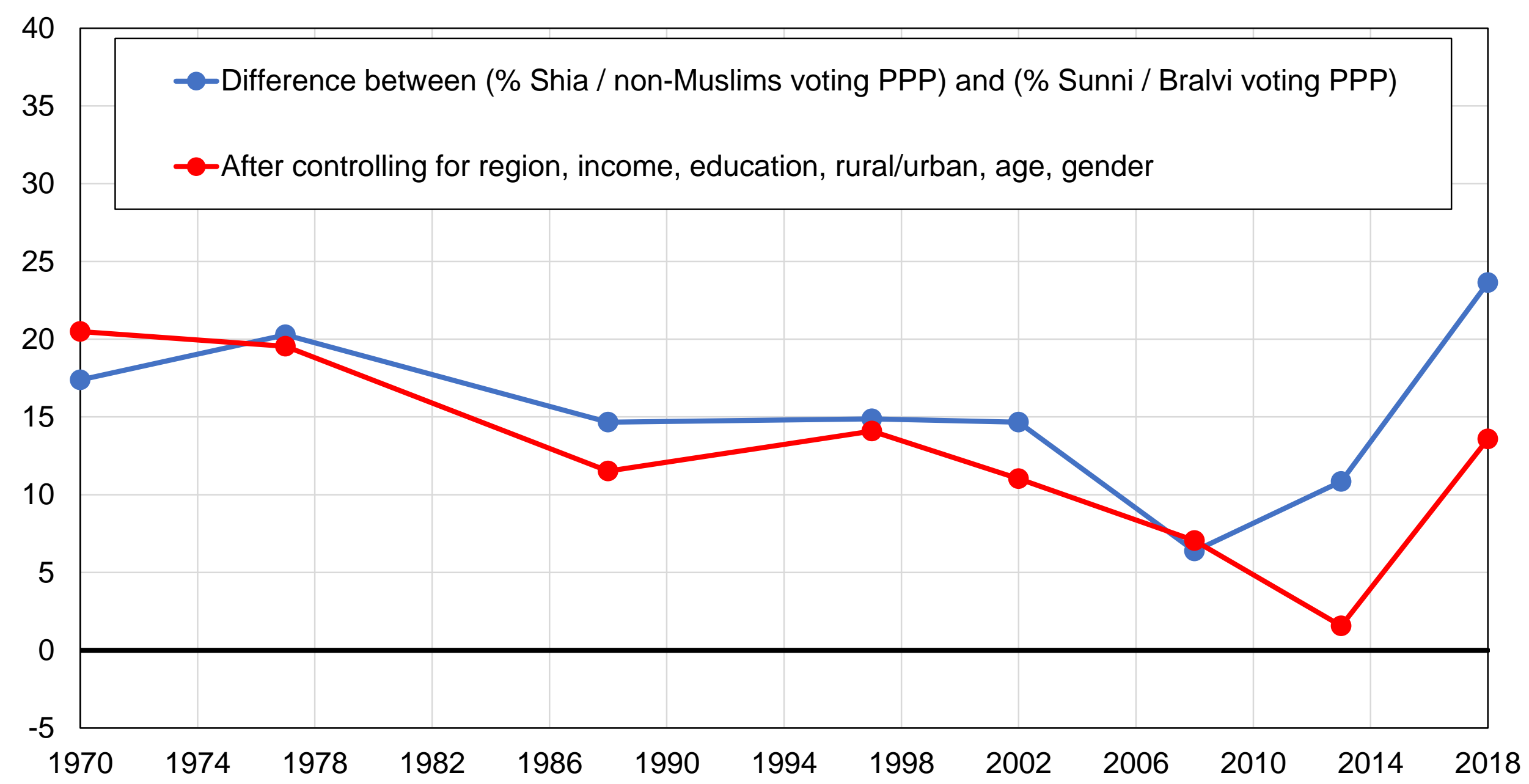

Source: authors' computations using Pakistani polls.

Note: the figure shows the difference between the share of Shia Muslims and non-Muslims voting PPP and the share of Sunni / Bralvi Muslims voting PPP, before and after controlling for other variables. 
Table 1 - Structure of the Pakistani electorate, 1988-2018

\begin{tabular}{|c|c|c|c|}
\hline & 1988 & 2002 & 2018 \\
\hline \multicolumn{4}{|l|}{ Provinces } \\
\hline Punjab & $58 \%$ & $57 \%$ & $54 \%$ \\
\hline Sindh & $24 \%$ & $24 \%$ & $28 \%$ \\
\hline Khyber Pakhtunkhwa & $14 \%$ & $14 \%$ & $12 \%$ \\
\hline Baluchistan & $5 \%$ & $5 \%$ & $6 \%$ \\
\hline \multicolumn{4}{|l|}{ Languages } \\
\hline Punjabi & $44 \%$ & $44 \%$ & $44 \%$ \\
\hline Saraekee & $11 \%$ & $10 \%$ & $10 \%$ \\
\hline Sindhi & $12 \%$ & $15 \%$ & $16 \%$ \\
\hline Urdu & $8 \%$ & $8 \%$ & $8 \%$ \\
\hline Pashto & $15 \%$ & $15 \%$ & $15 \%$ \\
\hline Balochi & $4 \%$ & $4 \%$ & $4 \%$ \\
\hline Others & $7 \%$ & $4 \%$ & $3 \%$ \\
\hline \multicolumn{4}{|c|}{$\begin{array}{l}\text { Source: authors' computations using census statistics (region, language, rural/urban) and Pakistani polls (other variables). Census statistics } \\
\text { refer to the overall population; other variables refer to the voting population. } \\
\text { Note: the table shows descriptive statistics for selected available variables. The rise in the reported share of Sunni Muslims may potentially be } \\
\text { attributable to migration of the Shia population to Iran, as well as to the rise of anti-Shia sentiments and consolidation of Sunni-supremacist } \\
\text { organizations, leading to underreporting of Shia identity. }\end{array}$} \\
\hline
\end{tabular}




\begin{tabular}{|l|cccccc|}
\hline \multicolumn{7}{|c|}{ Table 2 - Ethnolinguistic structure of Pakistani votes in 2018 } \\
\hline \multirow{2}{*}{ Balochi } & PPP & PML & PTI & Islamists & MQM & Others \\
\cline { 2 - 7 } Pashto & $7 \%$ & $7 \%$ & $15 \%$ & $18 \%$ & $0 \%$ & $52 \%$ \\
Punjabi & $8 \%$ & $7 \%$ & $54 \%$ & $15 \%$ & $0 \%$ & $15 \%$ \\
Saraekee & $5 \%$ & $41 \%$ & $31 \%$ & $7 \%$ & $0 \%$ & $17 \%$ \\
Sindhi & $8 \%$ & $32 \%$ & $34 \%$ & $5 \%$ & $1 \%$ & $20 \%$ \\
Urdu & $54 \%$ & $7 \%$ & $21 \%$ & $8 \%$ & $1 \%$ & $9 \%$ \\
\hline Source: authors' computations using Pakistani polls. & & & \\
Note: the table shows the share of votes received by Pakistani political parties by linguistic group in \\
2018. PPP: Pakistan People's Party. PML: Pakistan Muslim League and splits; PTI: Pakistan \\
Tehreek-e-Insaf; Islamists include the Muttahida Majlis-e-Amal and the Tehreek-e-Labbaik \\
Pakistan; MQM: Muttahida Qaumi Movement; Others mainly includes independent candidates. \\
\hline
\end{tabular}


Figure A1 - Election results in Pakistan by party group, 1970-2018

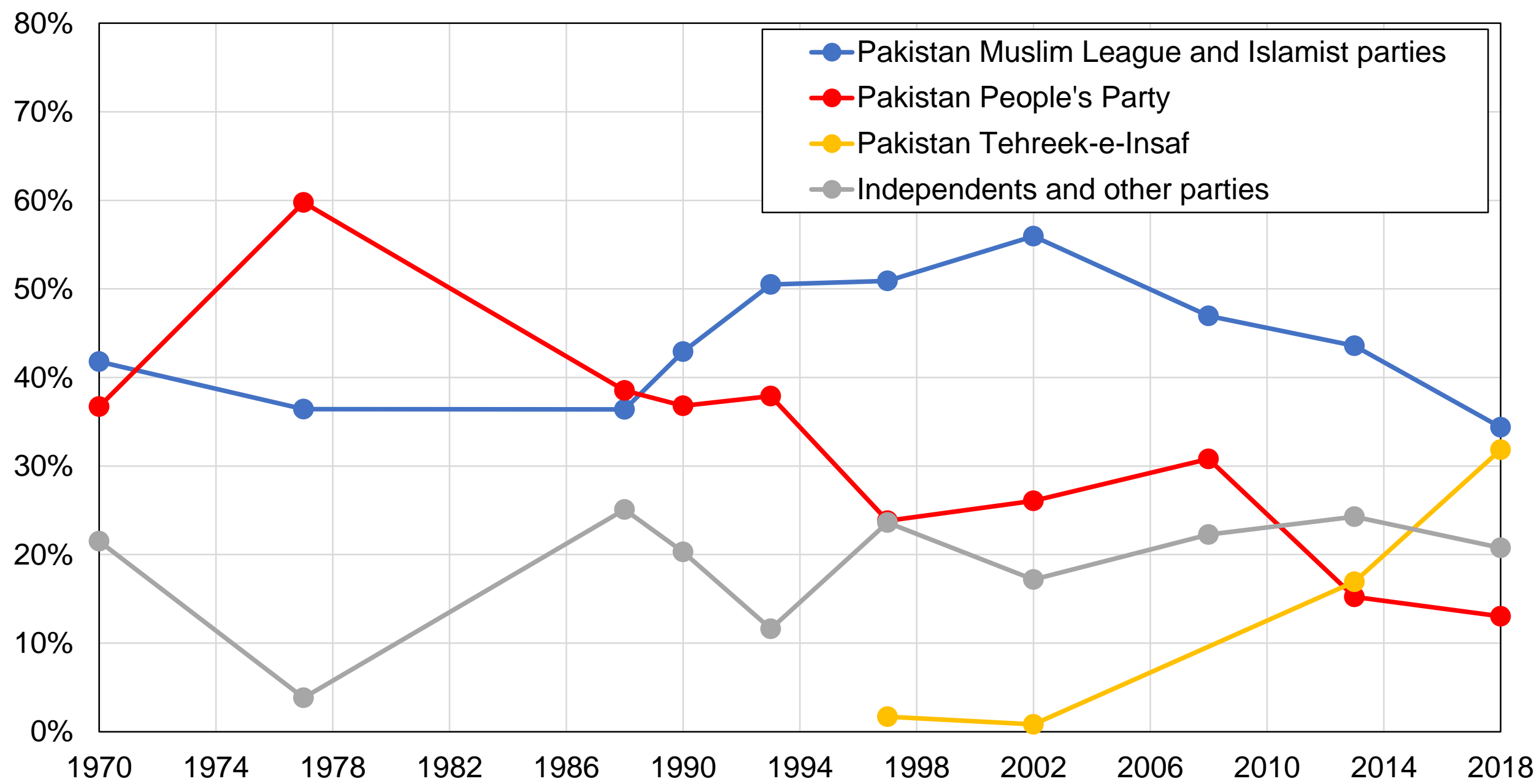

Source: authors' computations using official election results.

Note: the figure shows the share of votes received by selected groups of Pakistani political parties in general elections between 1970 and 2018. Figures for 1970 correspond to West Pakistan only. 
Figure A2 - Regional structure of Pakistani population, 1981-2018

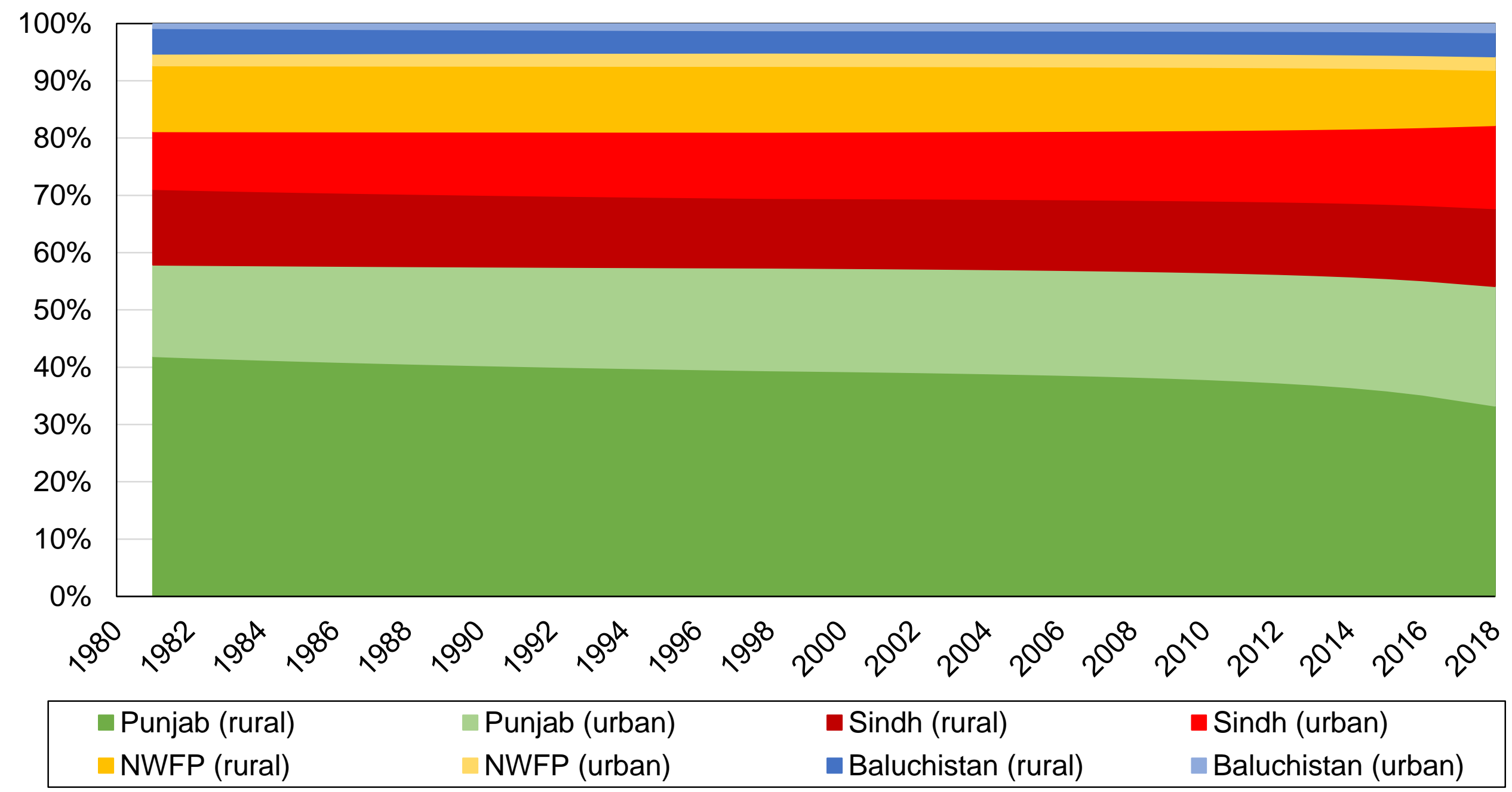

Source: authors' computations using Pakistani census data.

Note: the figure shows the share of the Pakistani population living in each of the four regions of Pakistan, decomposing rural and urban components for each region. 
Figure A3 - Linguistic composition of voters by region, 2018

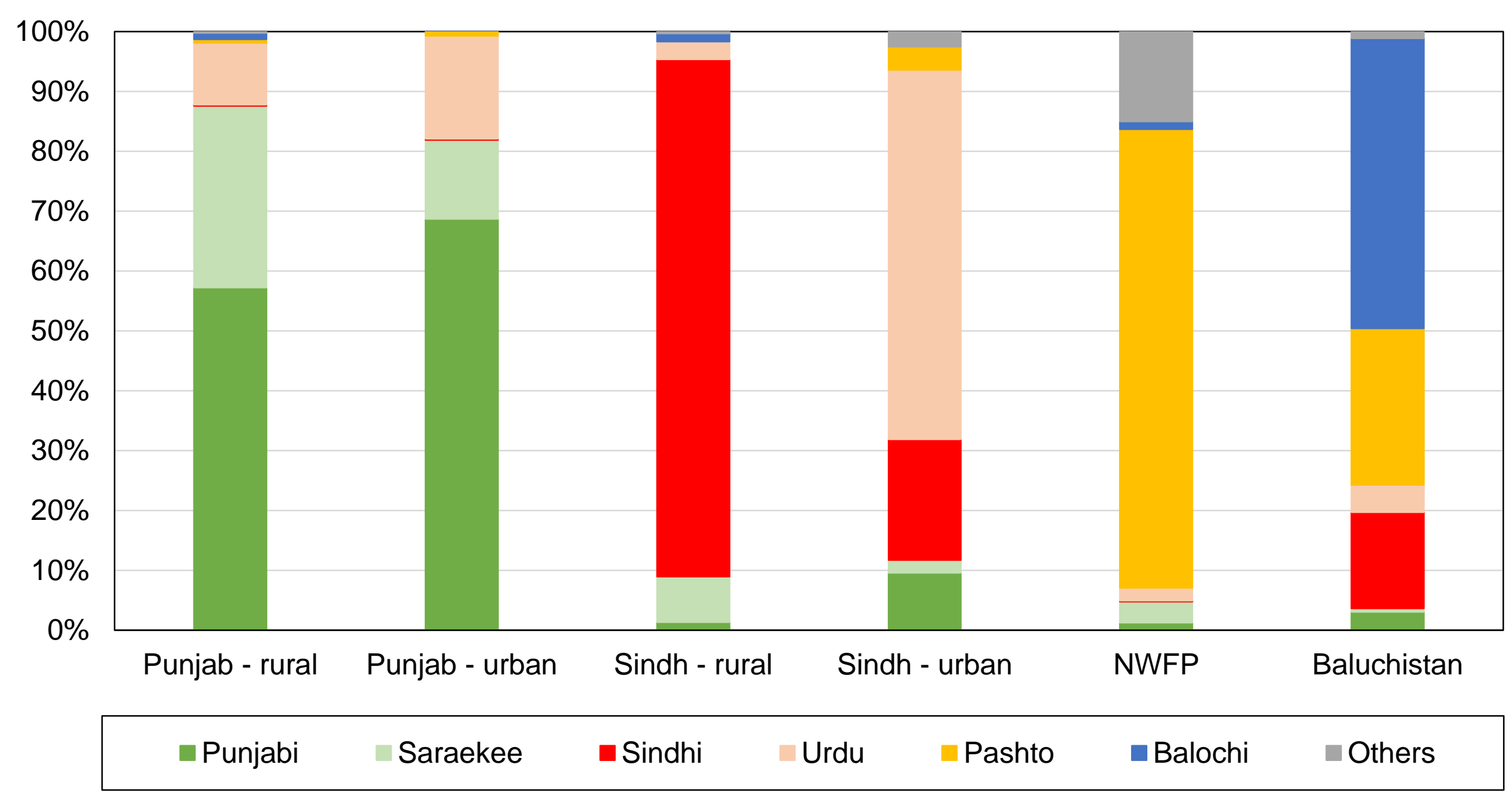

Source: authors' computations using Pakistani polls.

Note: the figure shows the linguistic composition of the four regions of Pakistan, decomposing rural and urban components for each region. Figures refer to the voting population. 
Figure A4 - Linguistic composition of income groups, 2018

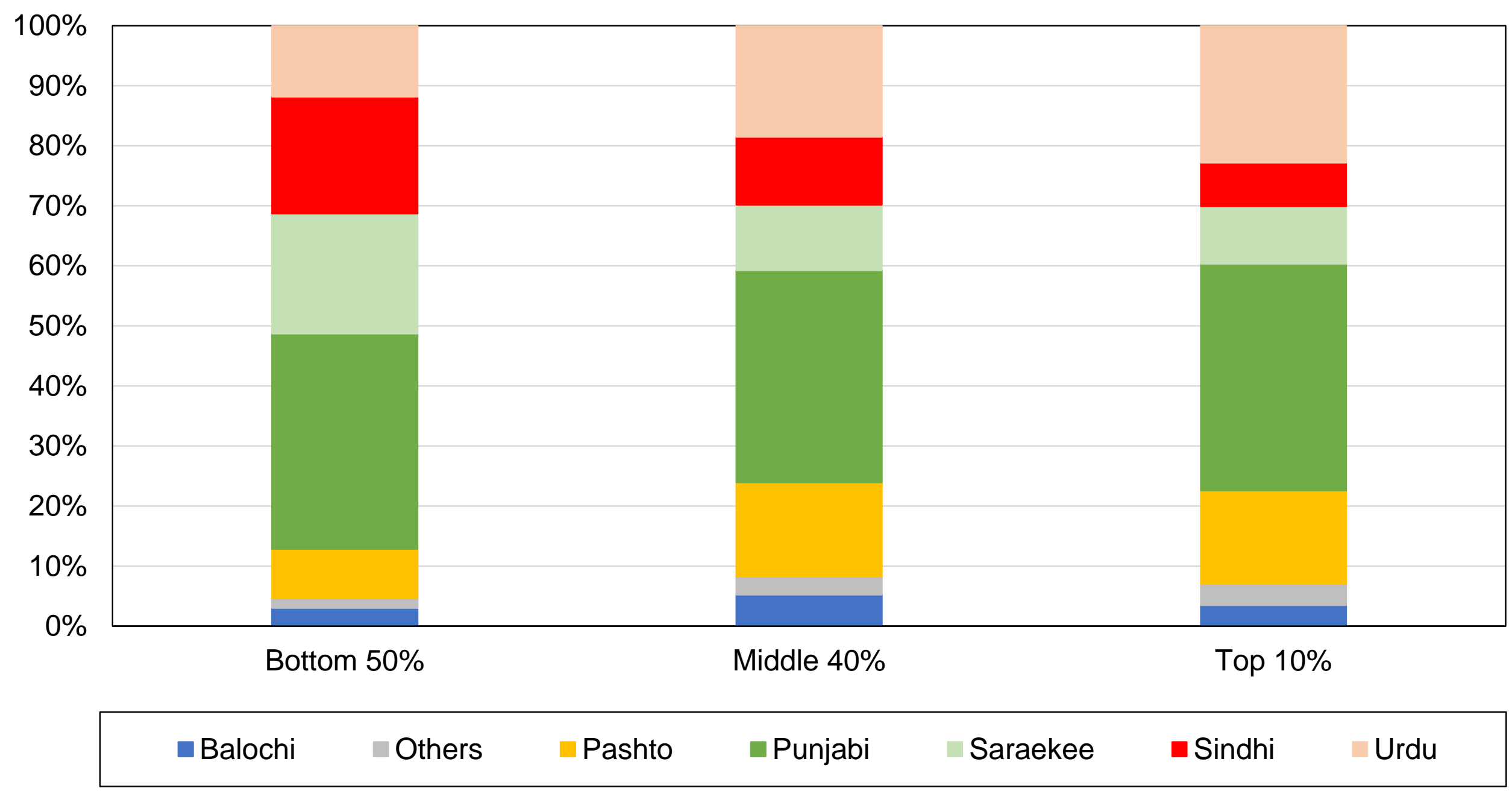

Source: authors' computations using Pakistani polls.

Note: the figure shows the linguistic composition of the poorest $50 \%$, the next $40 \%$, and the top $10 \%$ of earners among the Pakistani voting population in 2018. 
Figure A5 - Regional composition of income groups, 2018

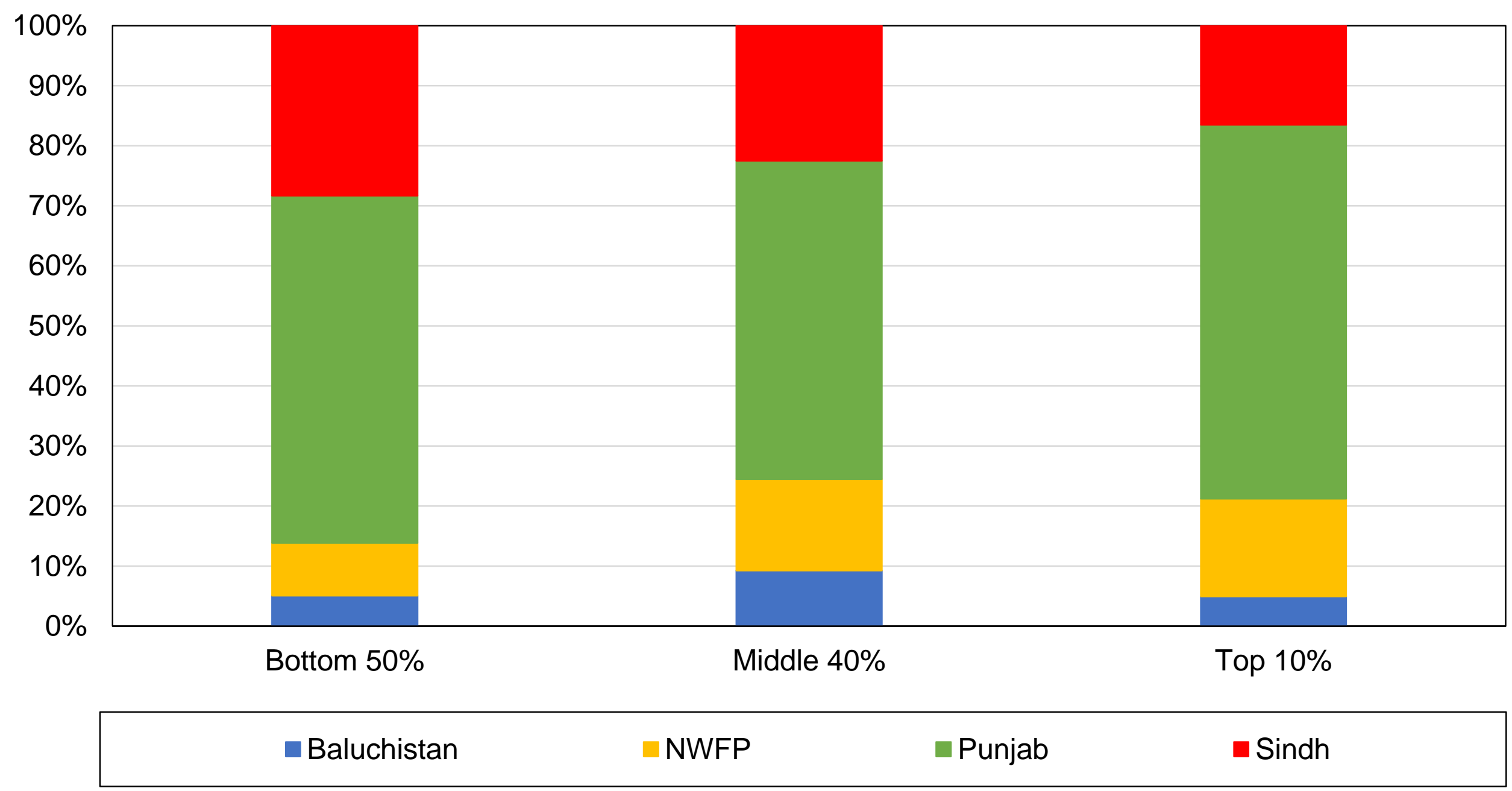

Source: authors' computations using Pakistani polls.

Note: the figure shows the regional composition of the poorest $50 \%$, the next $40 \%$, and the top $10 \%$ of earners among the Pakistani voting population in 2018. 
Figure A6 - Rural-urban composition of income groups, 2018

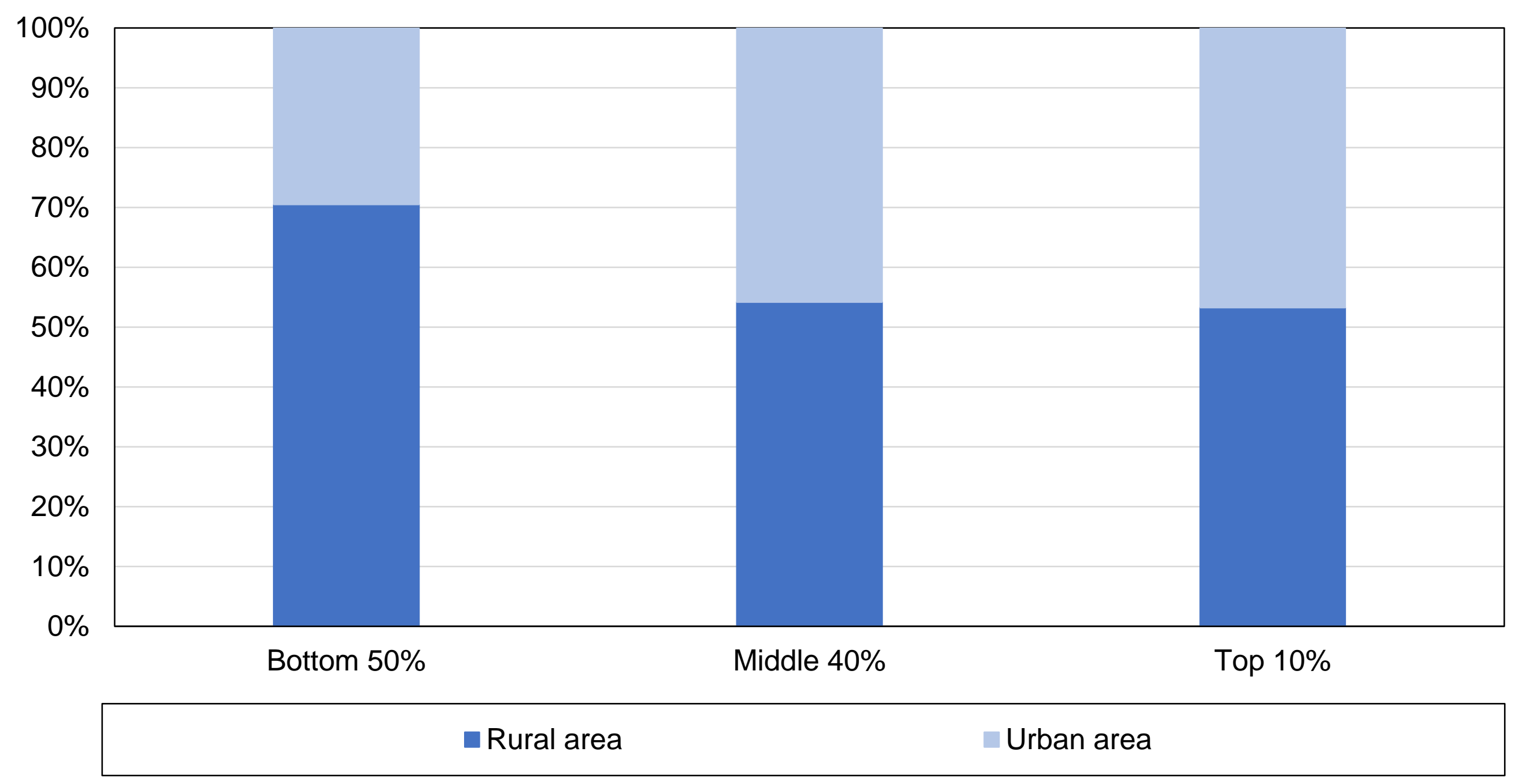

Source: authors' computations using Pakistani polls.

Note: the figure shows the rural / urban composition of the poorest $50 \%$, the next $40 \%$, and the top $10 \%$ of earners among the Pakistani voting population in 2018. 
Figure A7 - Vote for islamist parties by language, 1970-2018

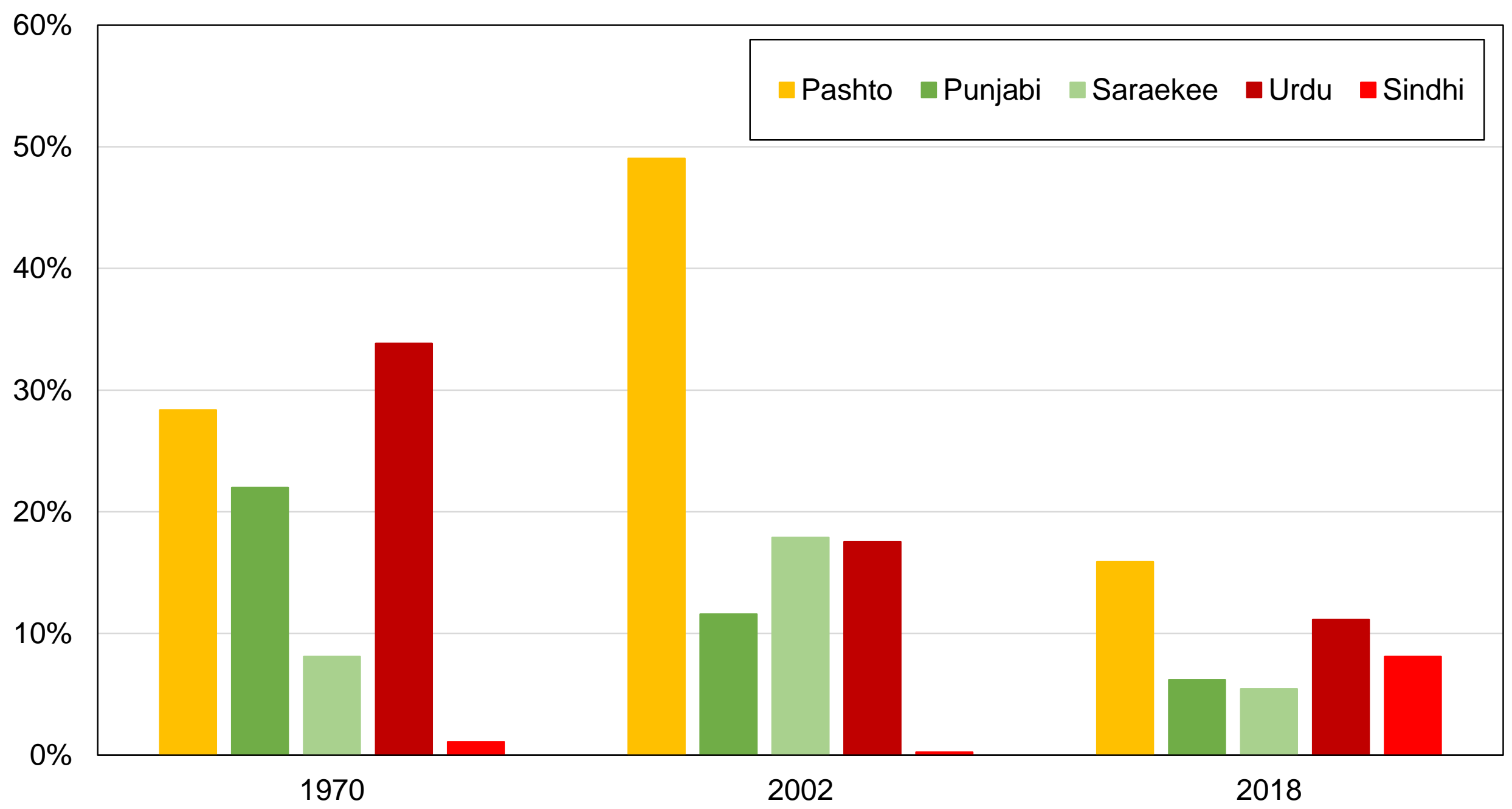

Source: authors' computations using Pakistani polls.

Note: the figure shows the share of voters supporting islamist parties in general elections by linguistic group. 
Figure A8 - Vote for the PTI by language, 2013-2018

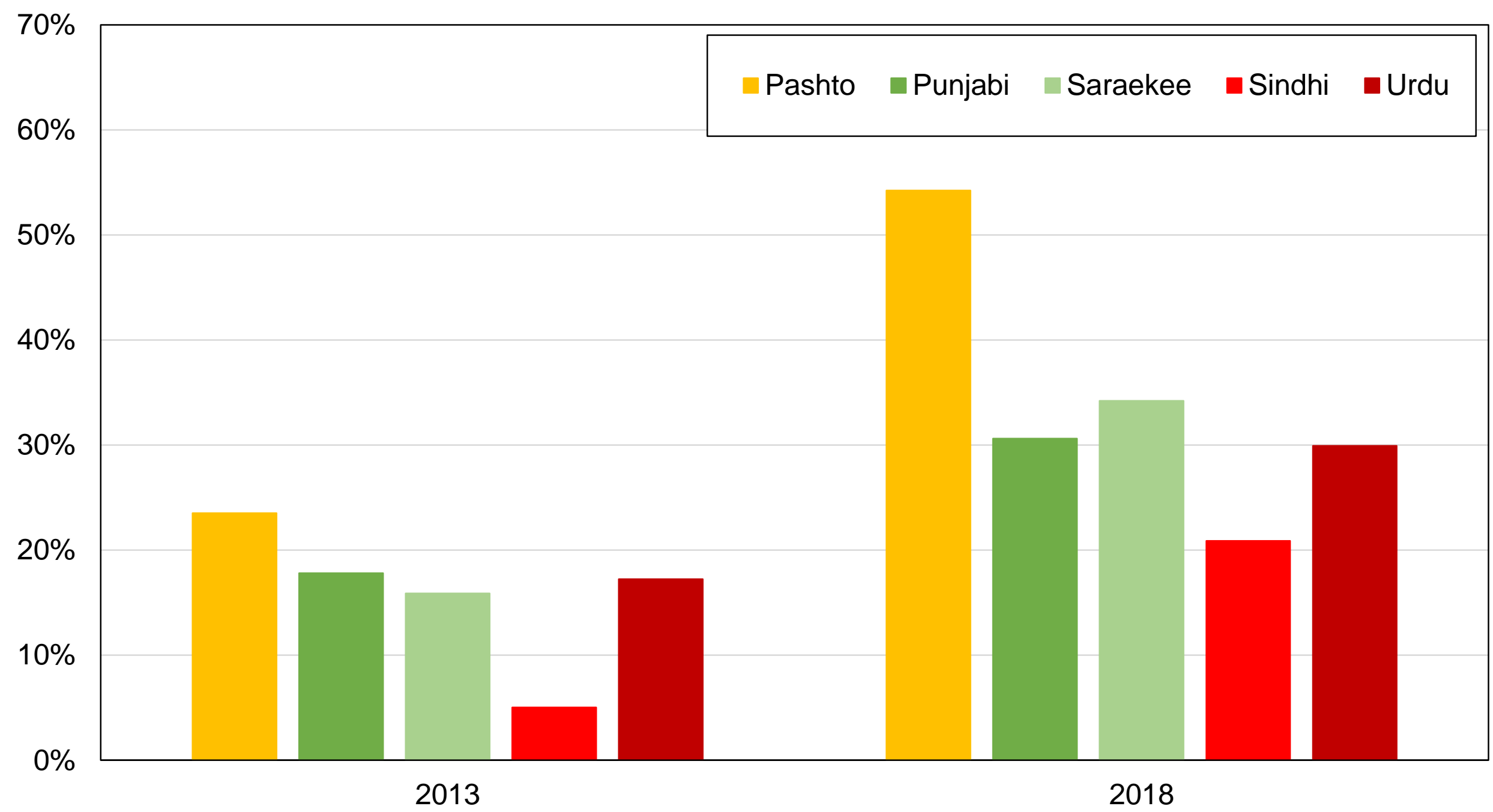

Source: authors' computations using Pakistani polls.

Note: the figure shows the share of voters supporting the PTI in general elections by linguistic group. 
Figure A9 - Vote for MQM by language, 1988-2018

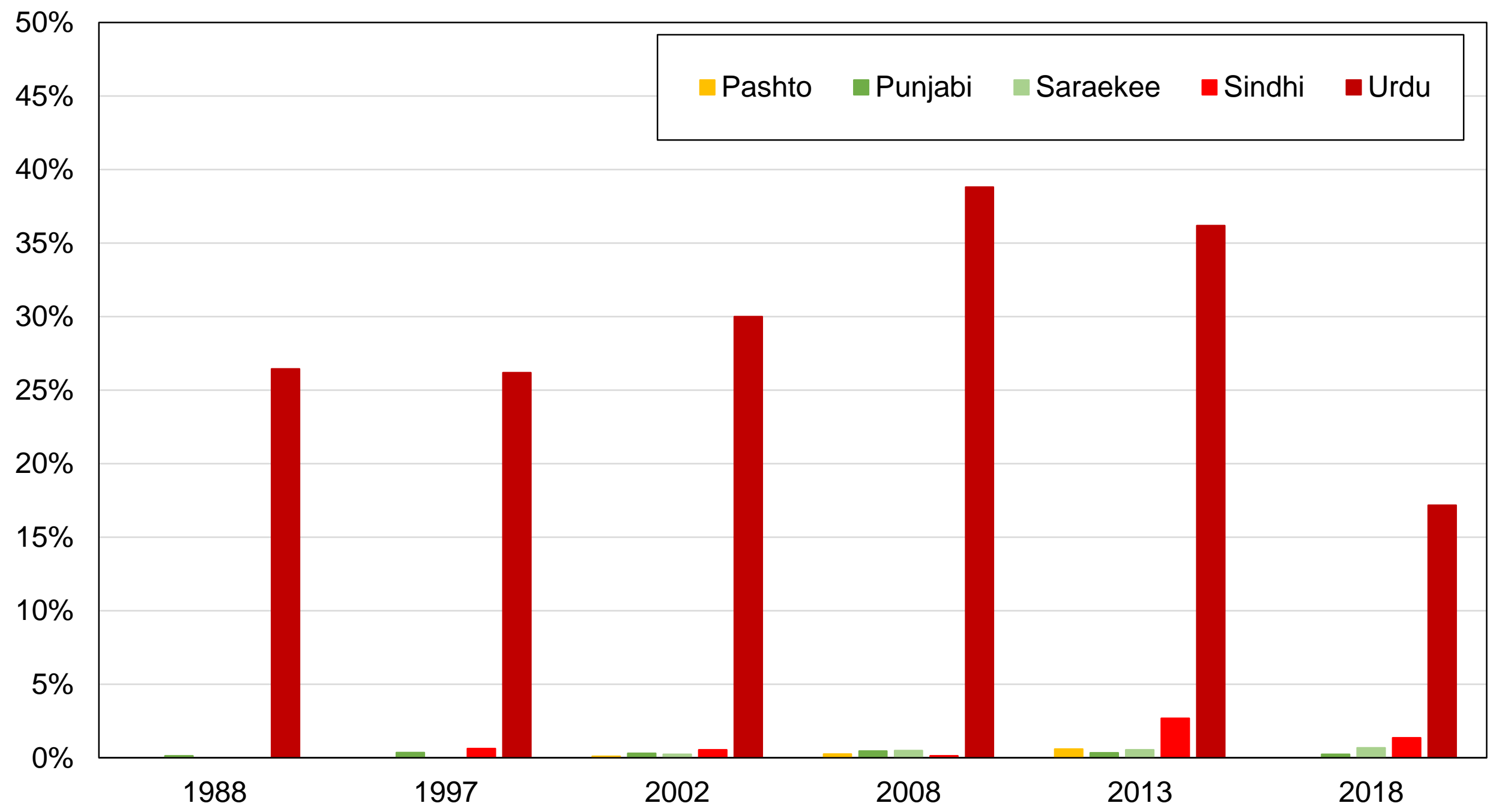

Source: authors' computations using Pakistani polls.

Note: the figure shows the share of voters supporting the MQM in general elections by linguistic group. 
Figure A10 - Vote for PML / IJI / PNA by income group, 1970-2018

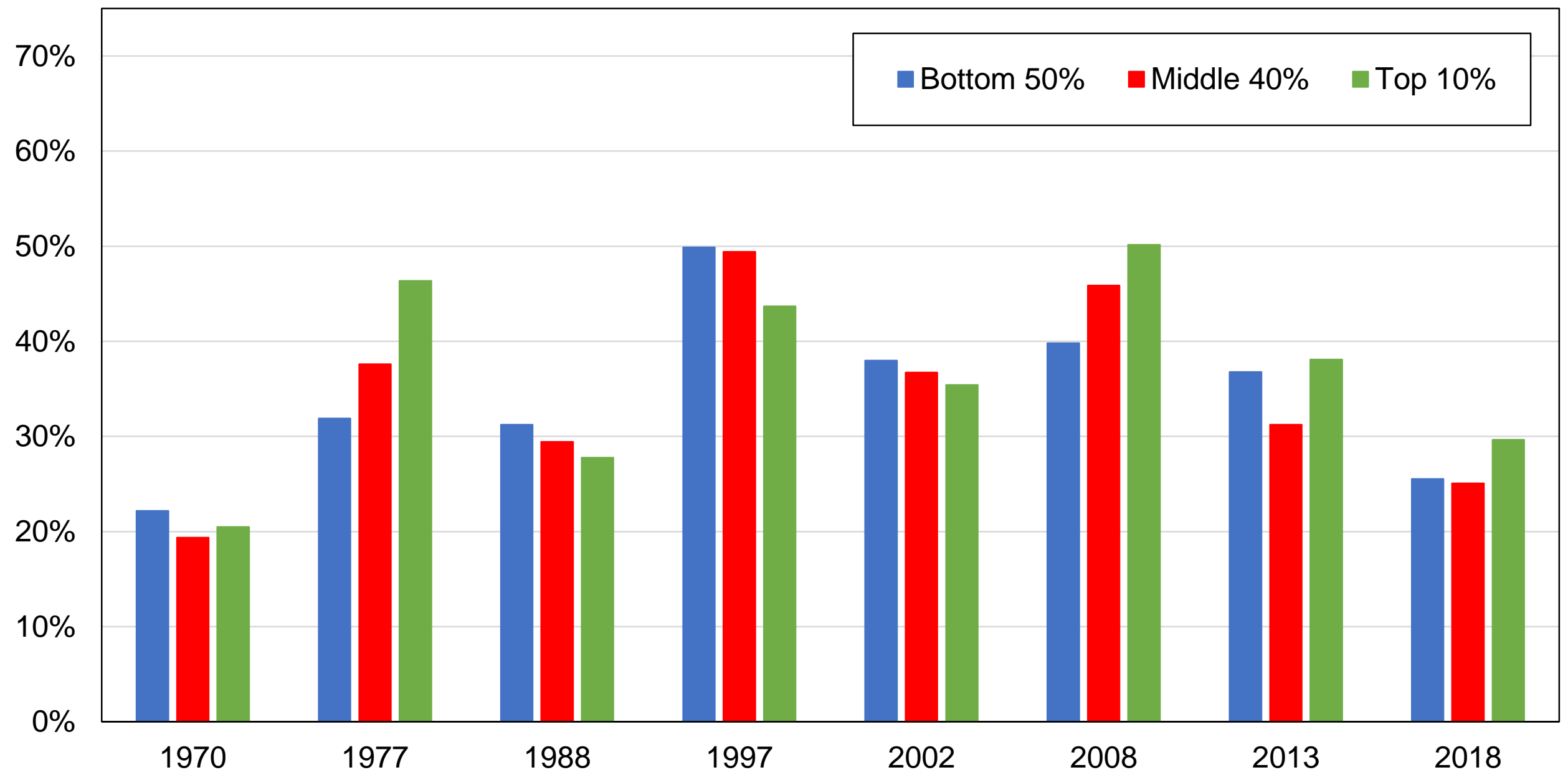

Source: author's computations using Pakistani polls.

Note: the figure shows the share of voters supporting the PML / IJI / PNA in general elections among the poorest $50 \%$ of voters, the next $40 \%$, and the top $10 \%$ of earners. 
Figure A11 - Vote for Islamist parties by income group, 1970-2018

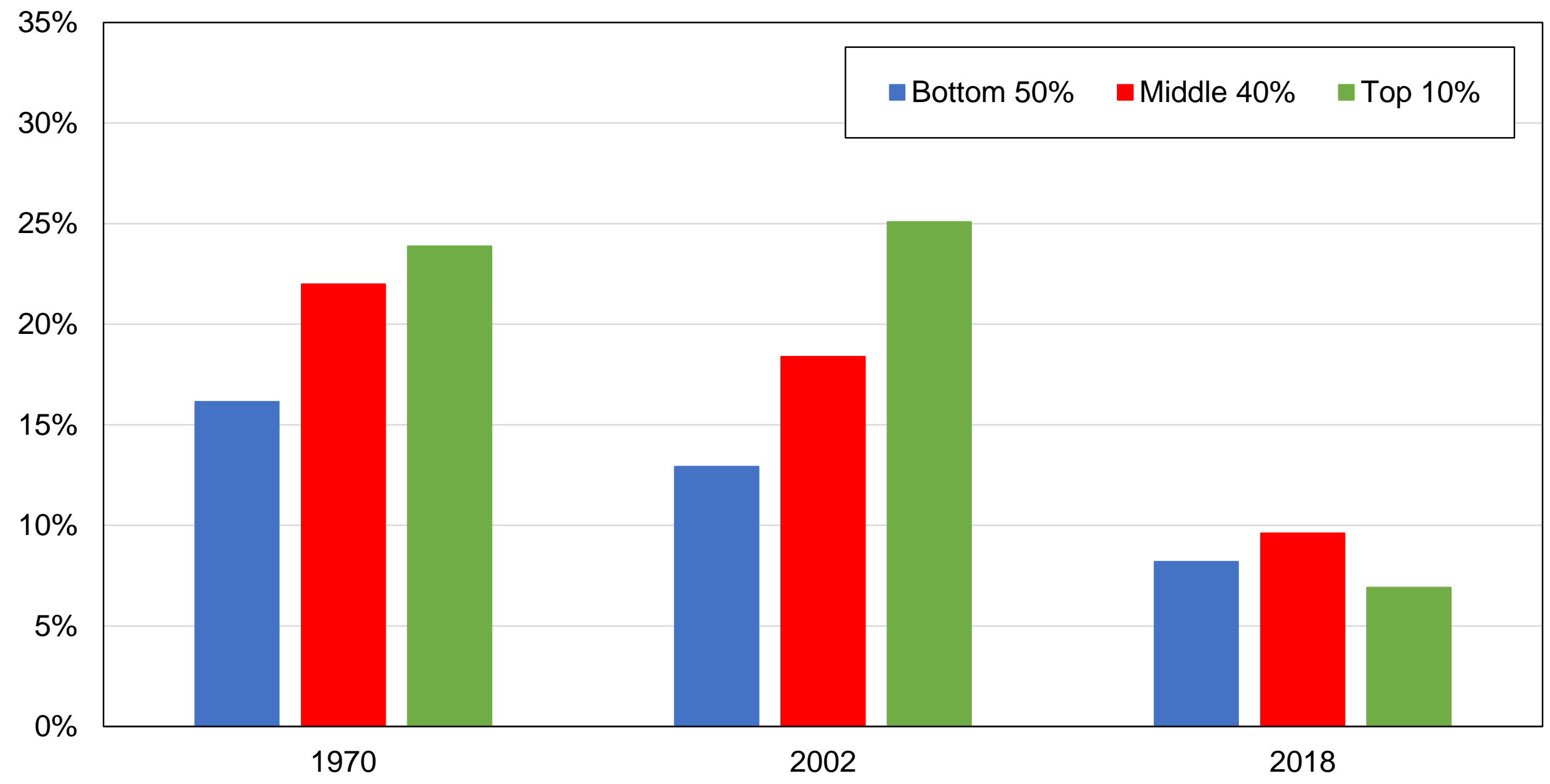

Source: author's computations using Pakistani polls.

Note: the figure shows the share of voters supporting islamist parties in general elections among the poorest $50 \%$ of voters, the next $40 \%$, and the top $10 \%$ of earners. 
Figure A12 - Vote for PTI by income group, 2013-2018

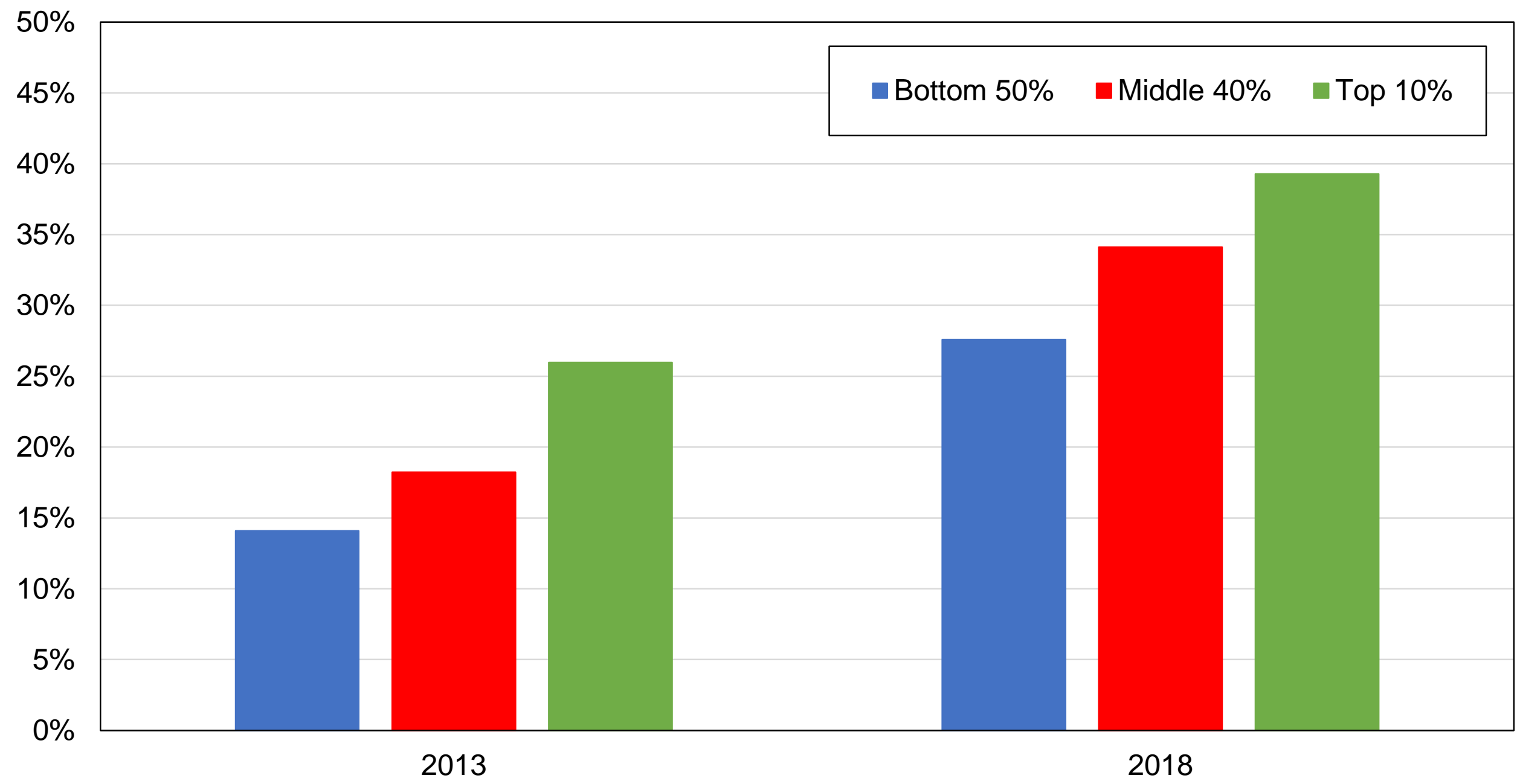

Source: author's computations using Pakistani polls.

Note: the figure shows the share of voters supporting the PTI in general elections among the poorest $50 \%$ of voters, the next $40 \%$, and the top $10 \%$ of earners. 
Figure A13 - Vote for PPP by education level, 1970-2018

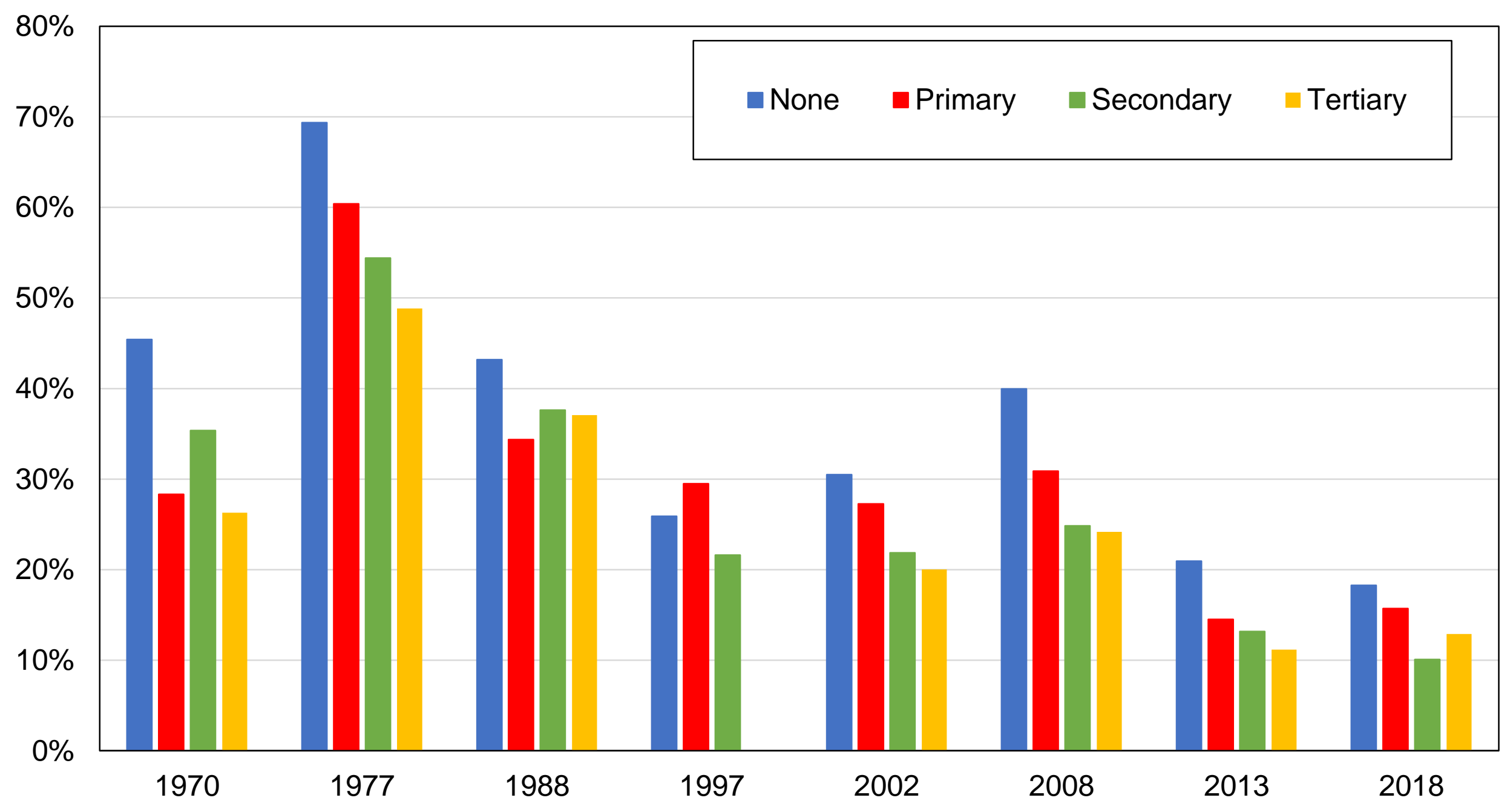

Source: authors' computations using Pakistani polls.

Note: the figure shows the share of voters supporting the PPP in general elections by education level. 
Figure A14 - Vote for islamist parties by education level, 1970-2018

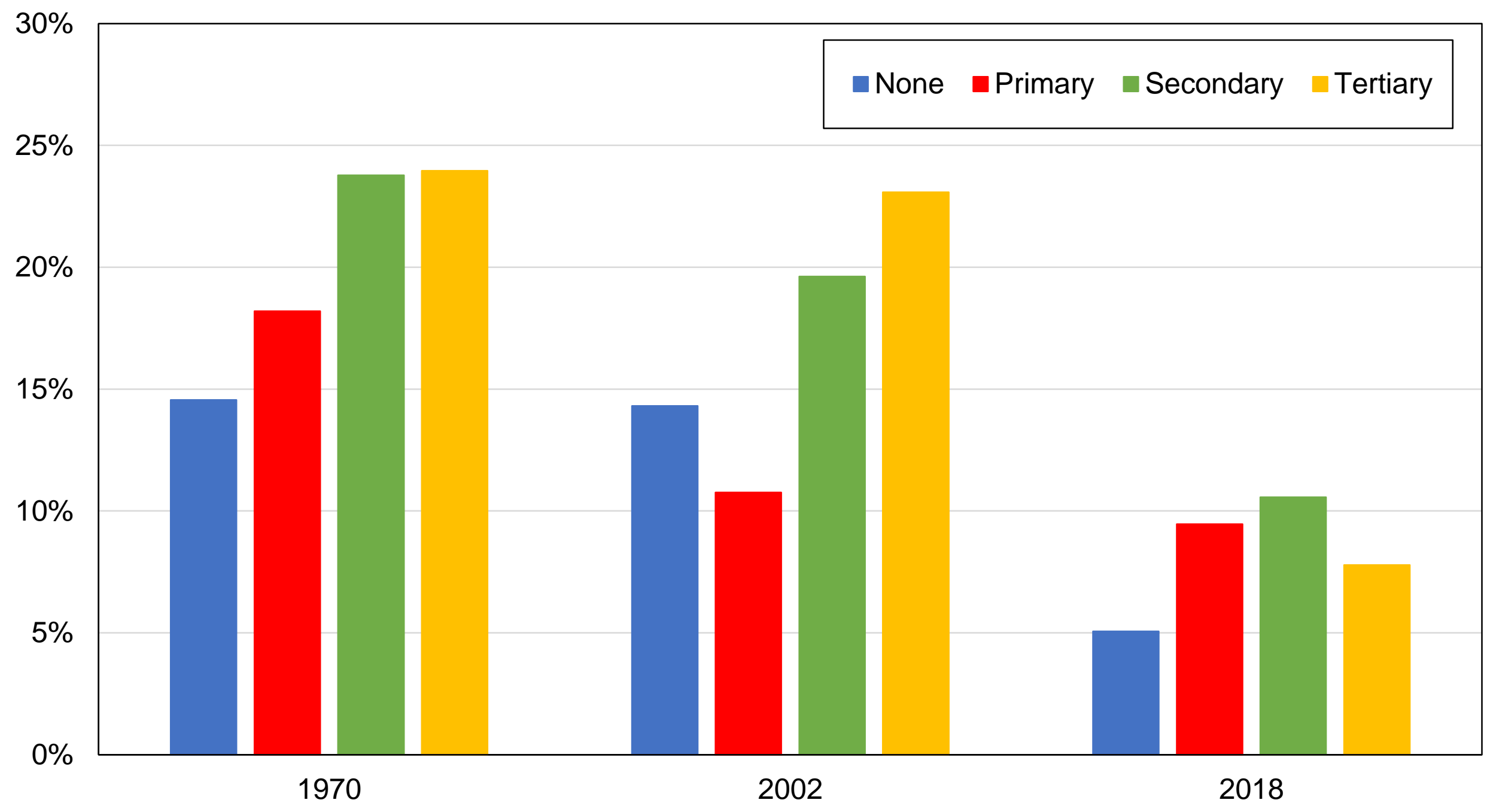

Source: authors' computations using Pakistani polls.

Note: the figure shows the share of voters supporting islamist parties in general elections by education level. 
Figure A15 - Vote for PTI by education level, 2013-2018

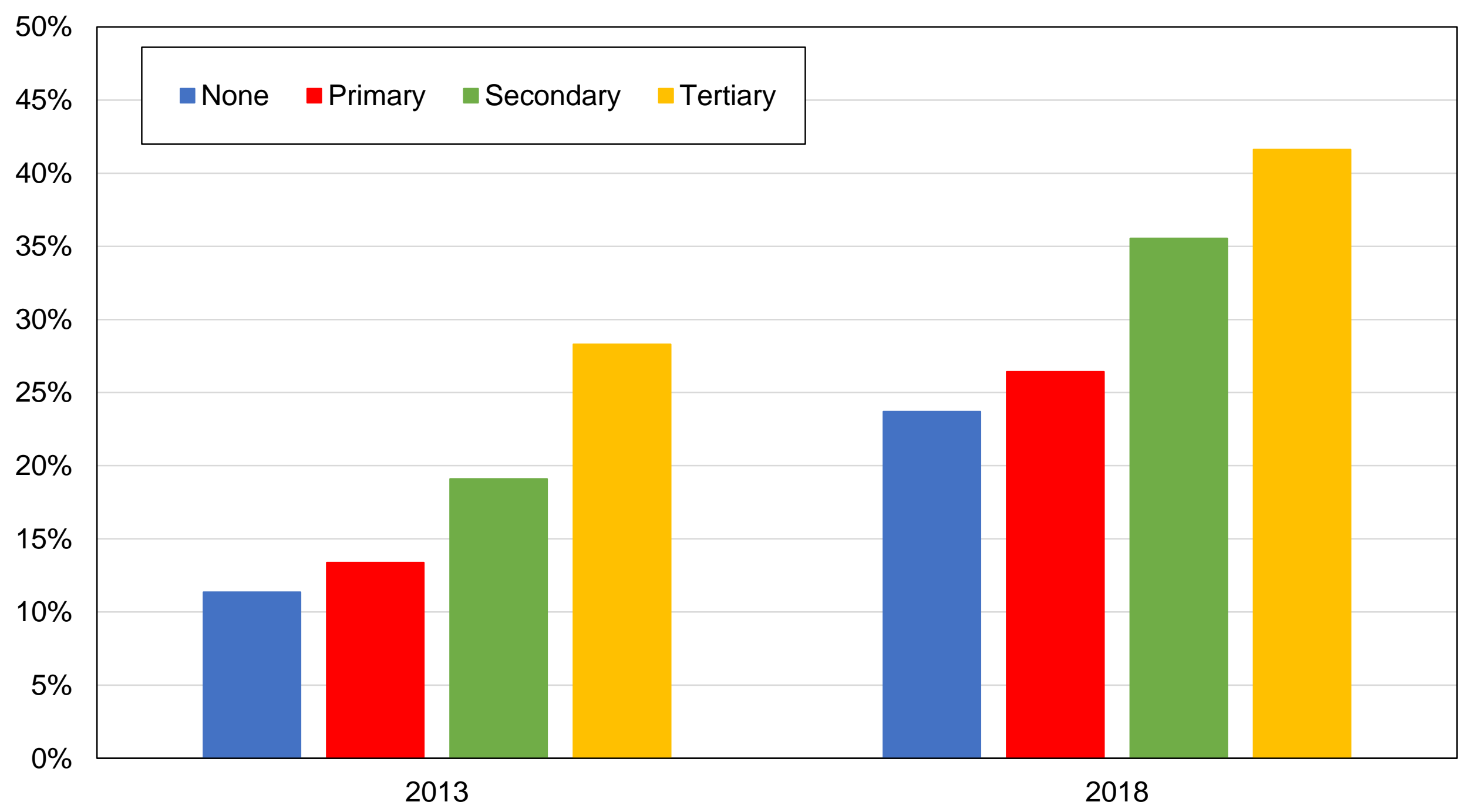

Source: authors' computations using Pakistani polls.

Note: the figure shows the share of voters supporting the PTI in general elections by education level. 
Figure A16 - Vote for PPP by education group, 1970-2018

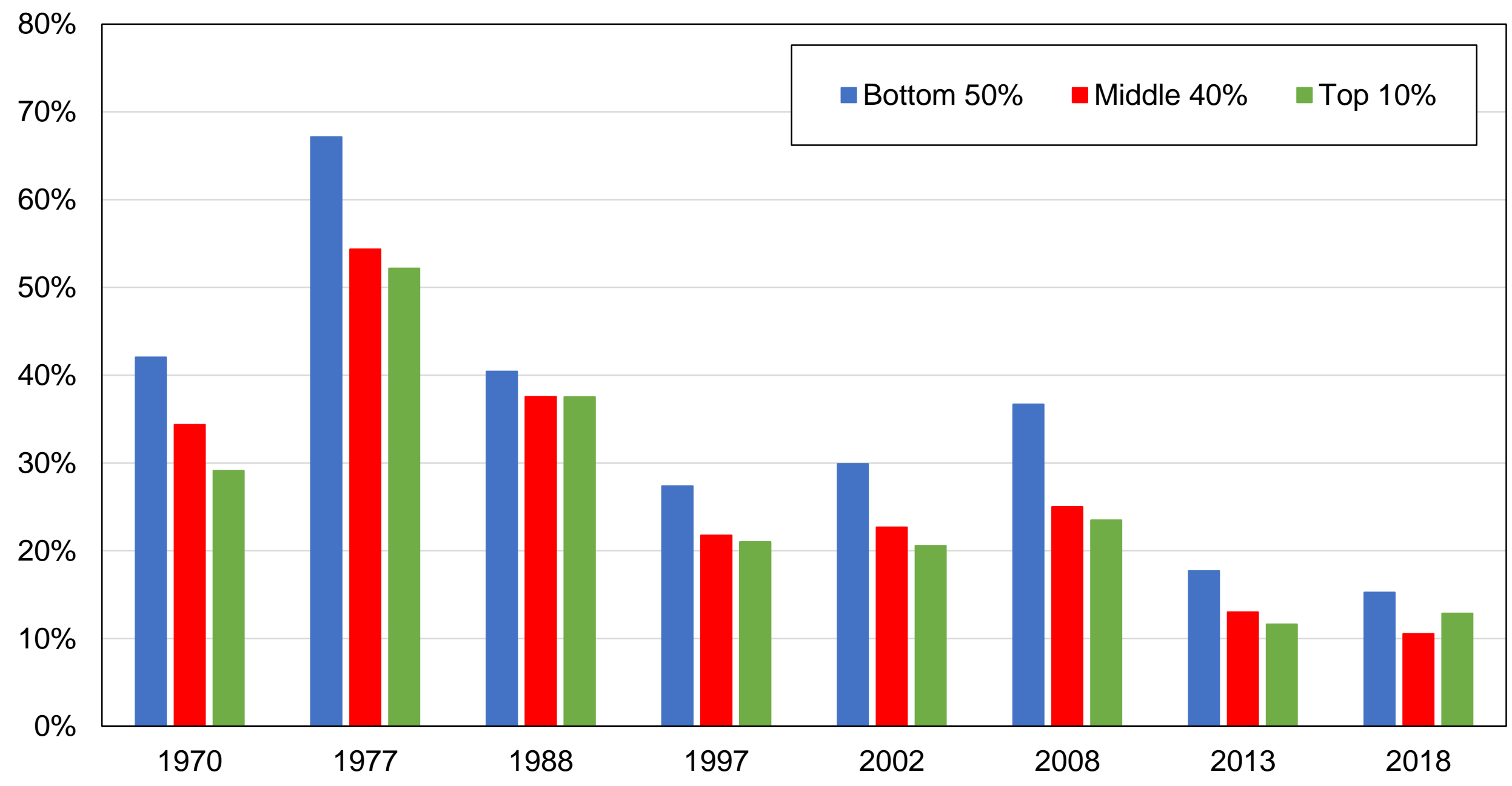

Source: authors' computations using Pakistani polls.

Note: the figure shows the share of voters supporting the PPP in general elections among the lowest $50 \%$, the next $40 \%$ and the top $10 \%$ of educated voters. 


\section{Figure A17 - Vote for the PPP among higher educated voters, 1970-2018}

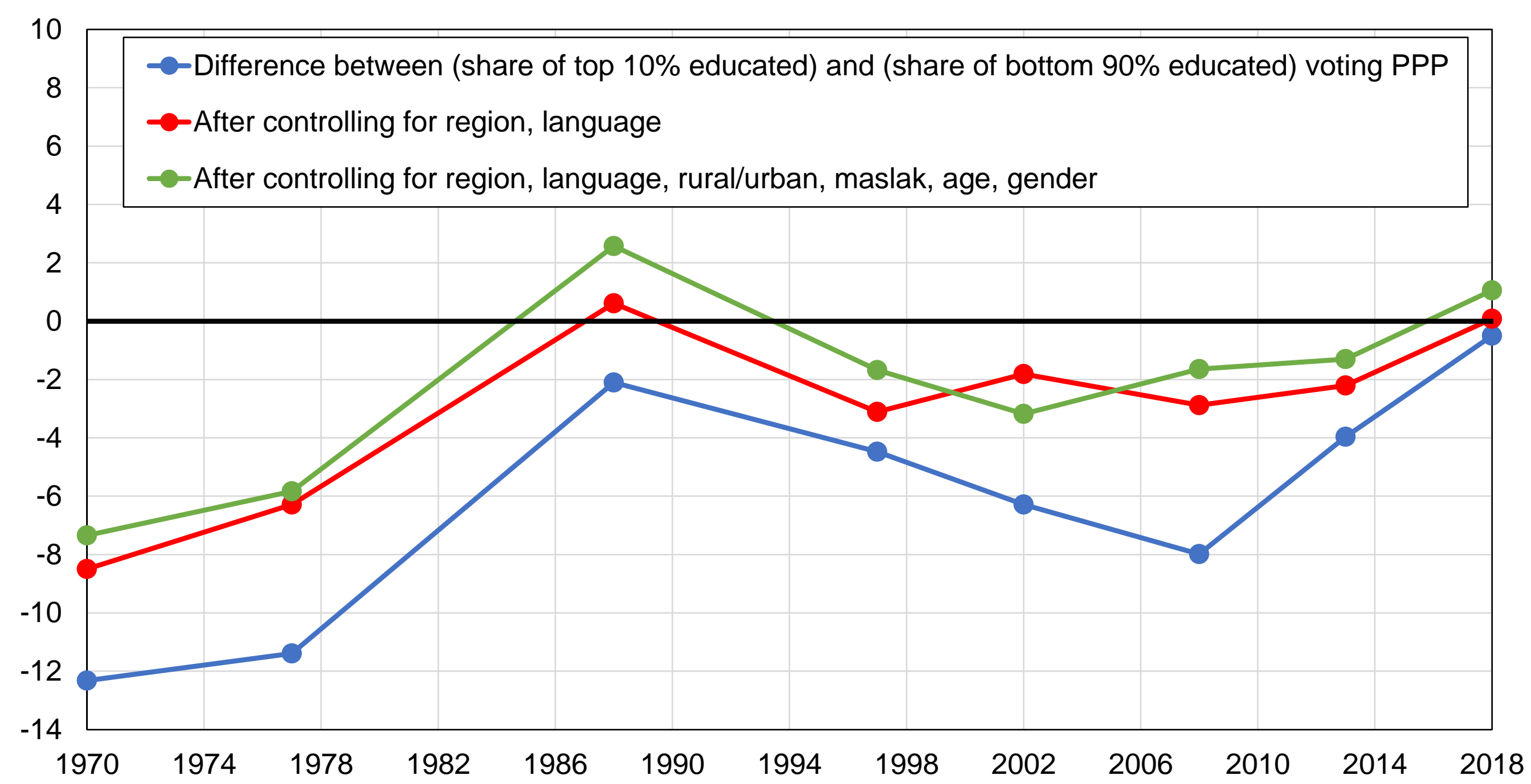

Source: authors' computations using Pakistani polls.

Note: the figure shows the difference between the share of top 10\% educated voters voting PPP and the share of bottom $90 \%$ educated voters voting PPP, before and after controlling for other variables. 
Figure A18 - Vote for PML / IJI / PNA by education group, 1970-2018

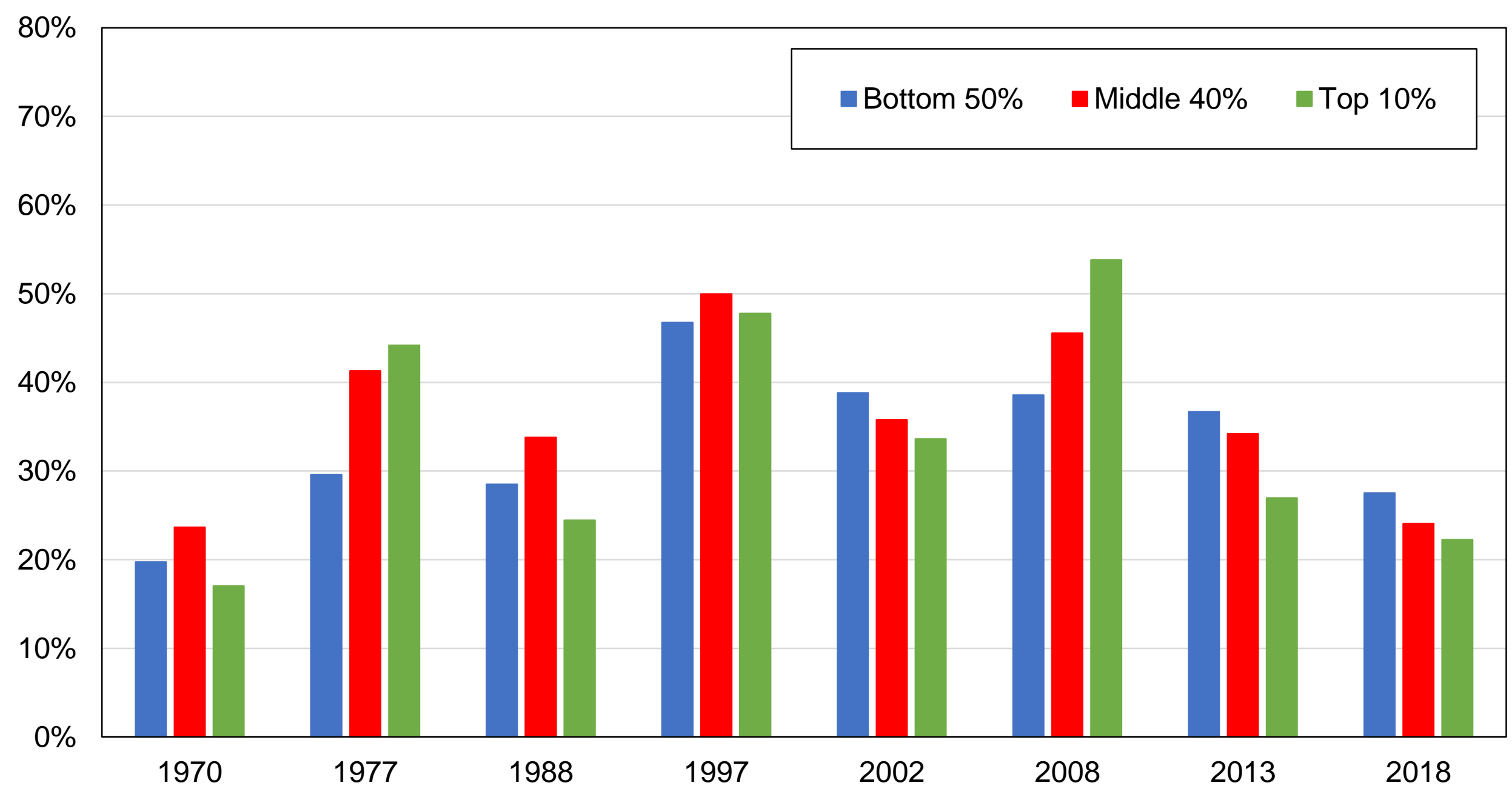

Source: authors' computations using Pakistani polls.

Note: the figure shows the share of voters supporting the PML / IJI / PNA in general elections among the lowest $50 \%$, the next $40 \%$ and the top $10 \%$ of educated voters. 
Figure A19 - Vote for Islamist parties by education group, 1970-2018

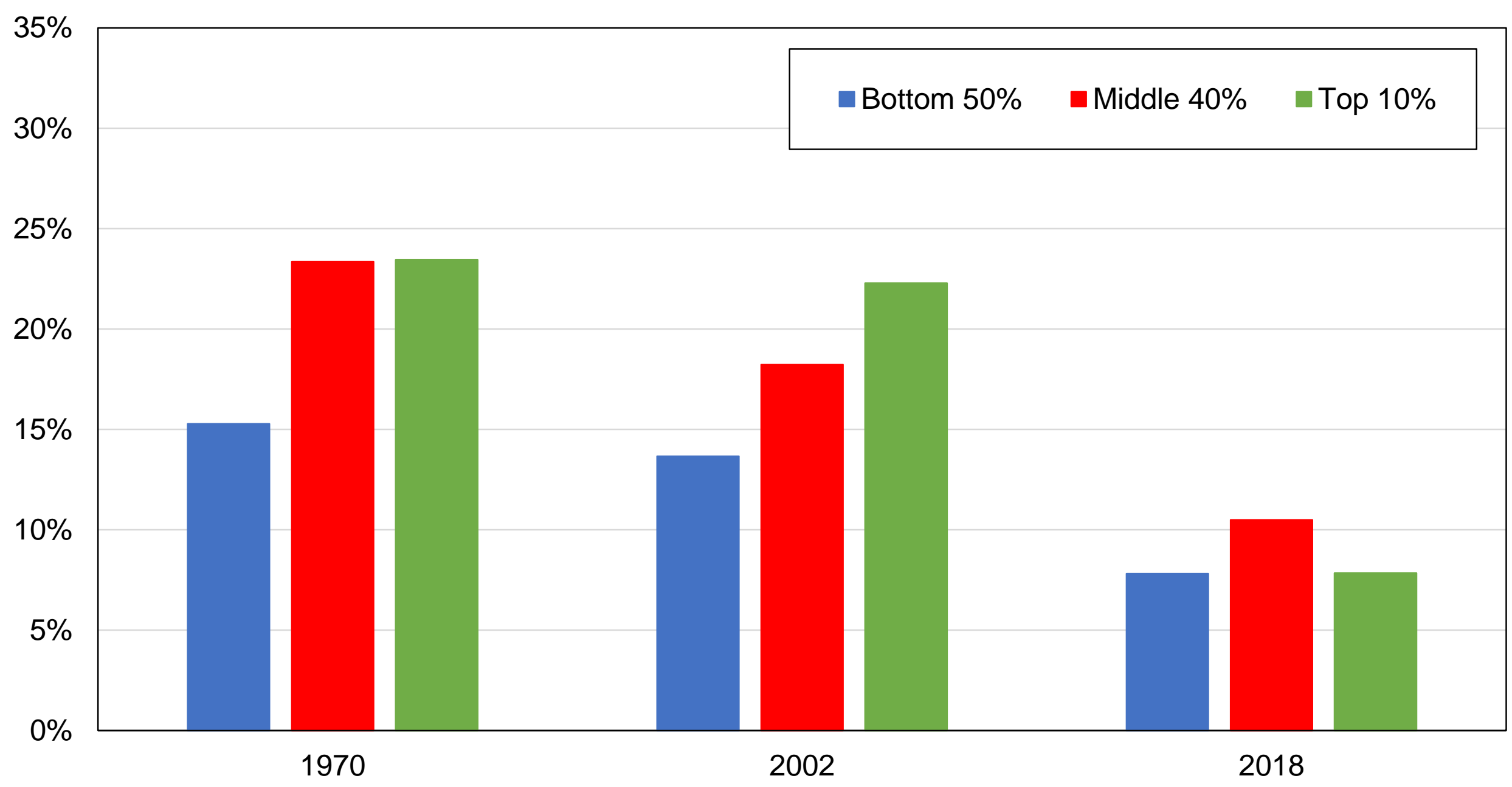

Source: authors' computations using Pakistani polls.

Note: the figure shows the share of voters supporting islamist parties in general elections among the lowest $50 \%$, the next $40 \%$ and the top $10 \%$ of educated voters. 
Figure A20 - Vote for PTI by education group, 2013-2018

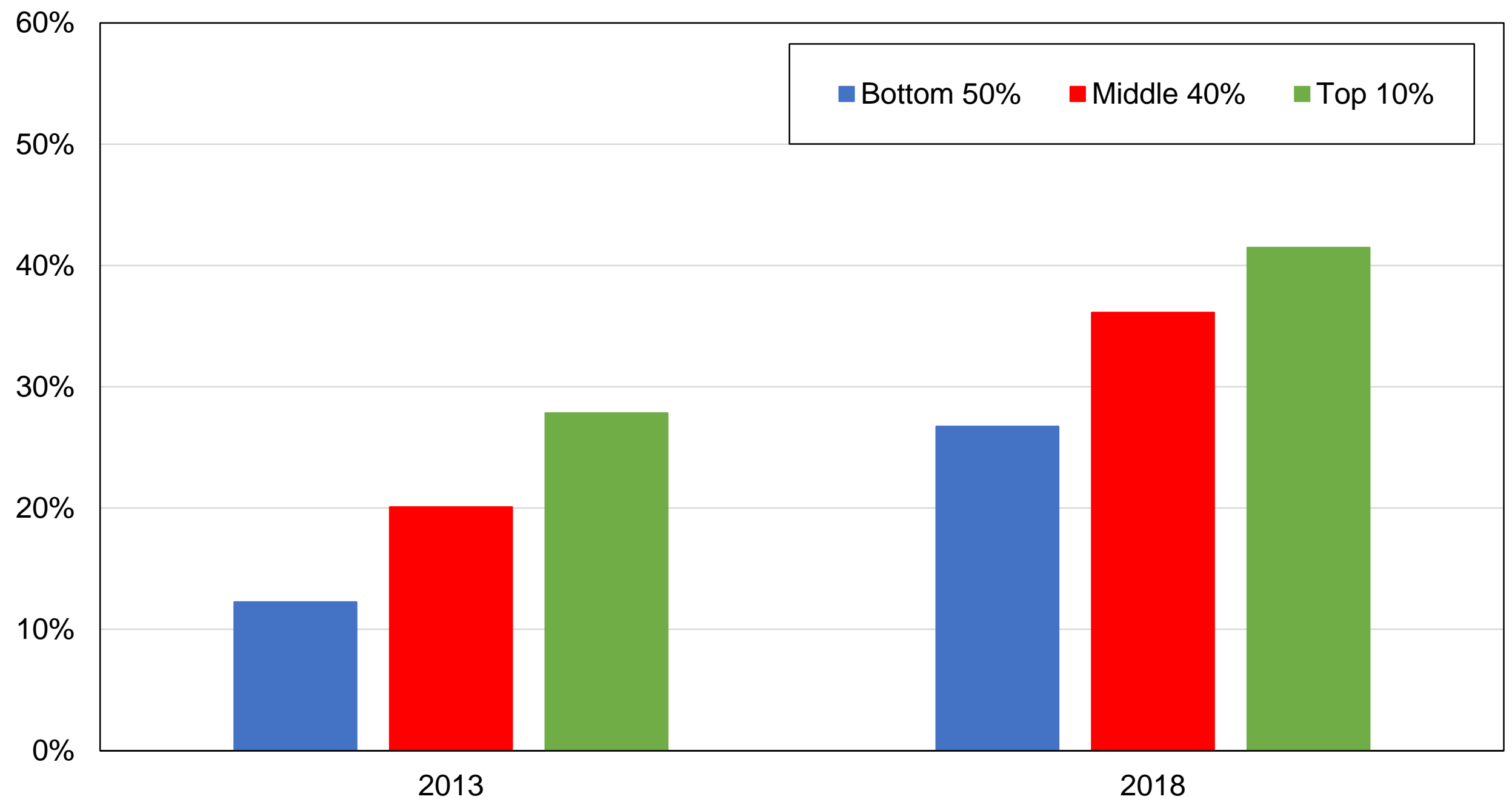

Source: authors' computations using Pakistani polls.

Note: the figure shows the share of voters supporting the PTI in general elections among the lowest $50 \%$, the next $40 \%$ and the top $10 \%$ of educated voters. 
Figure A21 - Vote for PML / IJI / PNA by religious affiliation, 1970-2018

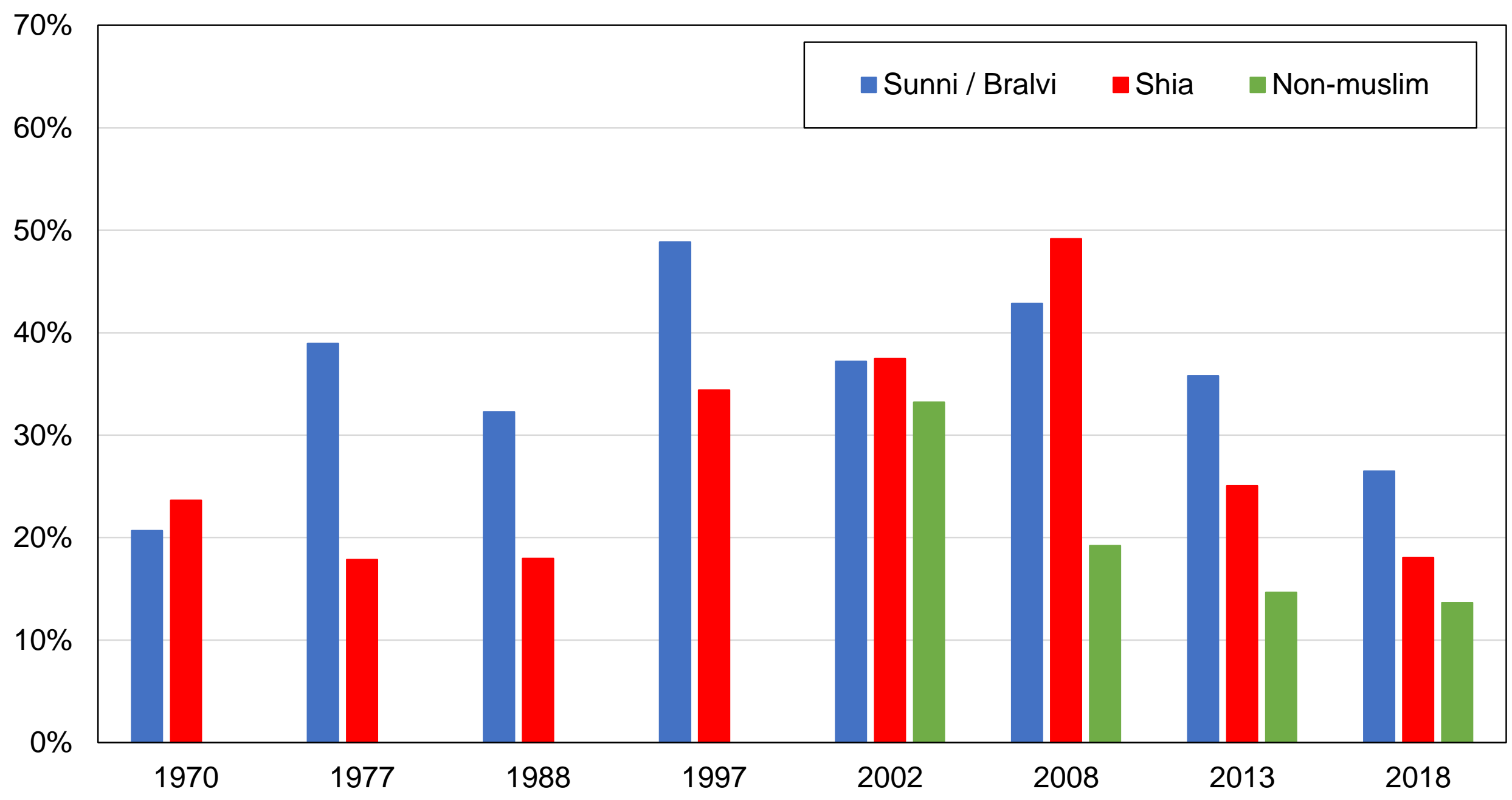

Source: authors' computations using Pakistani polls.

Note: the figure shows the share of voters supporting the PML / IJI / PNA in general elections by religious affiliation. 
Figure A22 - Vote for Islamist parties by religious affiliation, 1970-2018

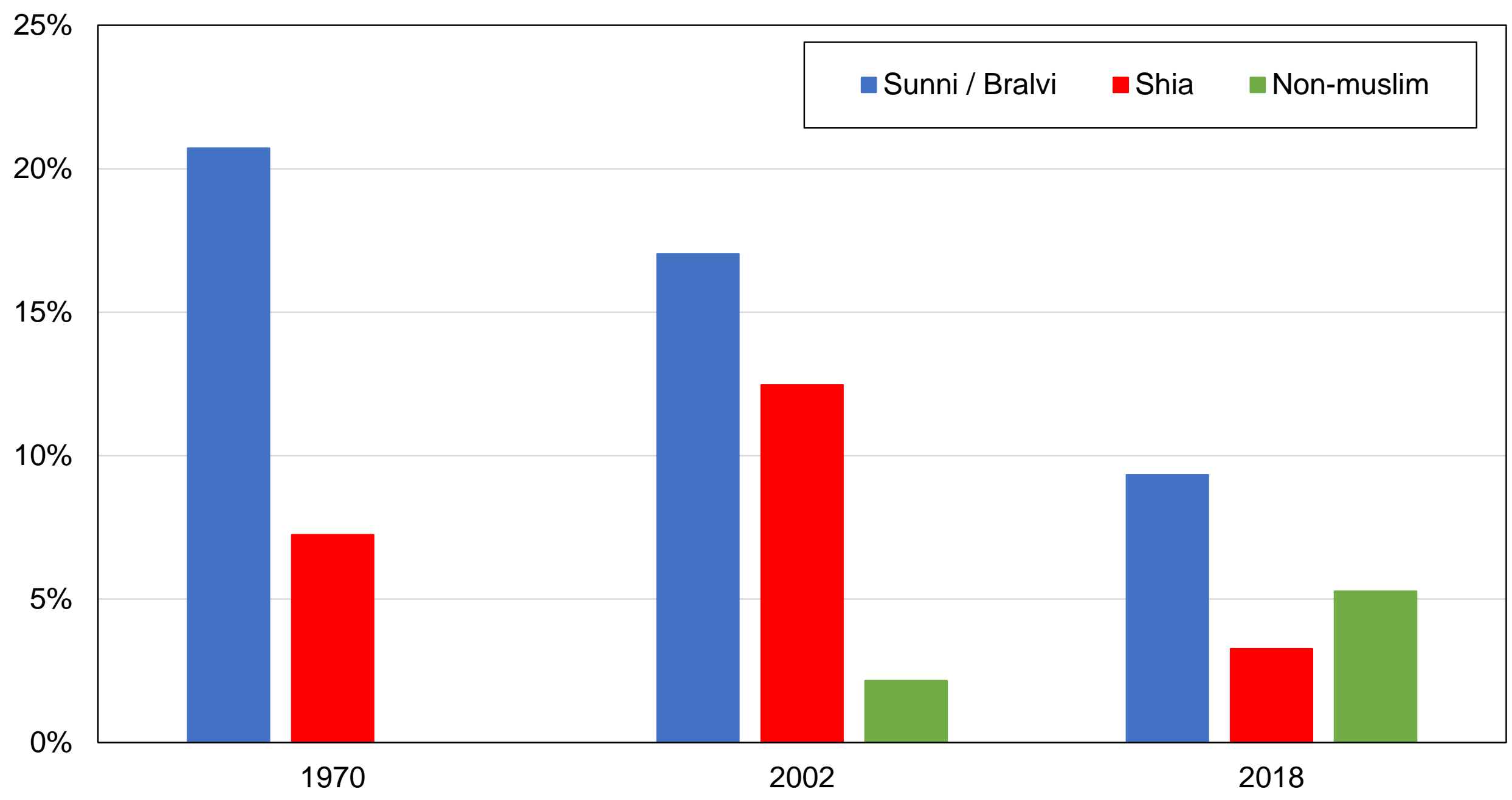

Source: authors' computations using Pakistani polls.

Note: the figure shows the share of voters supporting islamist parties in general elections by religious affiliation. 
Figure A23 - Vote for PTI by religious affiliation, 2013-2018

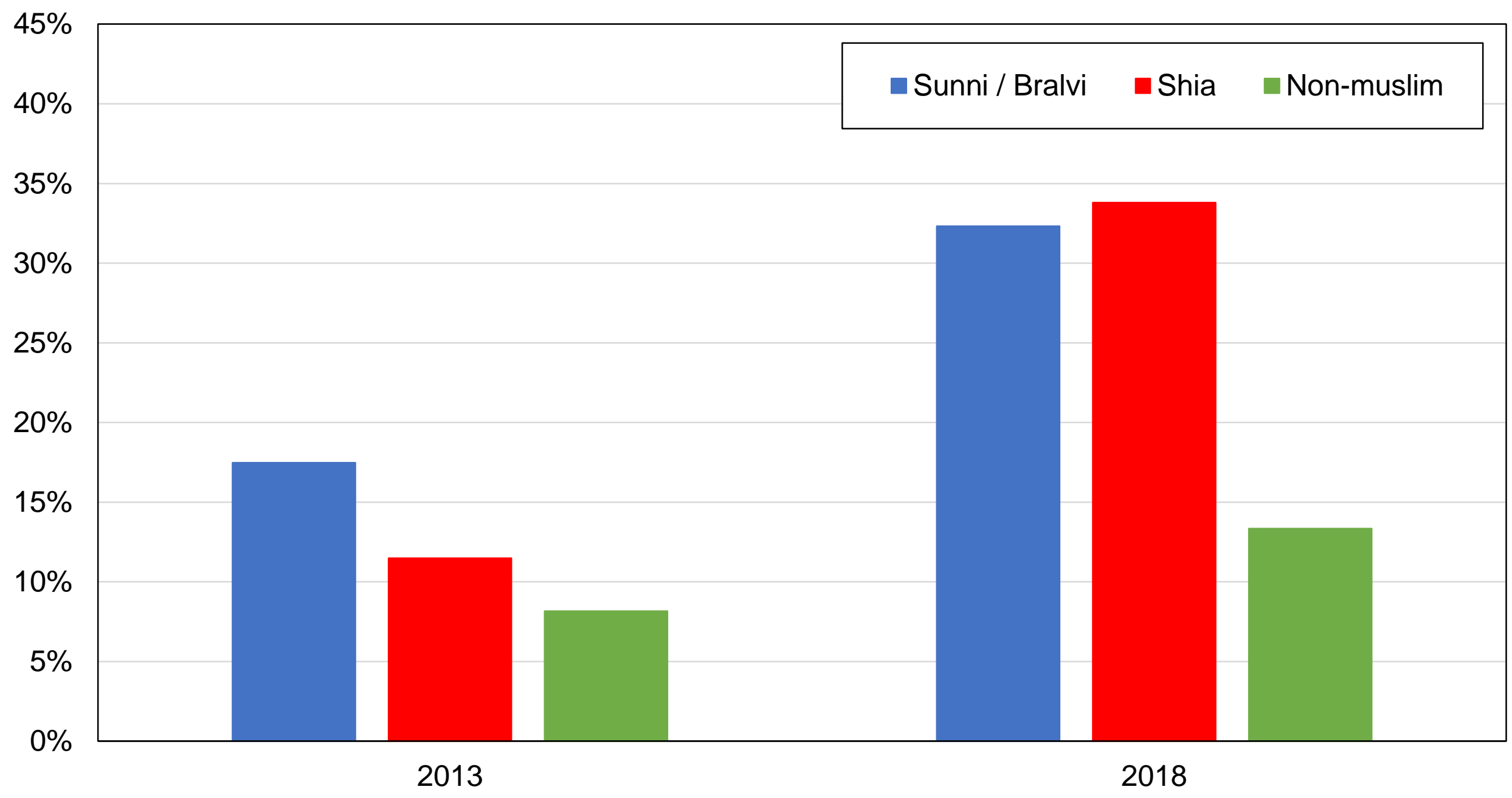

Source: authors' computations using Pakistani polls.

Note: the figure shows the share of voters supporting the PTI in general elections by religious affiliation. 
Table A1 - Share of seats won by party and province in the Pakistan 1970 provincial elections

\begin{tabular}{l|ccccc|}
\hline & East Pakistan & Punjab & Sindh & NWFP & Balochistan \\
\cline { 2 - 5 } Awami League & $96 \%$ & $0 \%$ & $0 \%$ & $0 \%$ & $0 \%$ \\
Pakistan Peoples Party & $0 \%$ & $63 \%$ & $47 \%$ & $8 \%$ & $0 \%$ \\
Muslim League Parties & $0 \%$ & $15 \%$ & $15 \%$ & $33 \%$ & $15 \%$ \\
Islamist Parties & $1 \%$ & $4 \%$ & $13 \%$ & $13 \%$ & $10 \%$ \\
National Awami Party & $0 \%$ & $0 \%$ & $0 \%$ & $33 \%$ & $40 \%$ \\
Independents / Other & $3 \%$ & $18 \%$ & $25 \%$ & $15 \%$ & $35 \%$ \\
\hline Source: adapted from C. Baxter, "Pakistan Votes - 1970", Asian Survey 11, no. 3 (1971): 197-218. \\
Note: the table shows the share of seats received in the 1970 provincial elections by party and province. Muslim \\
League Parties include the Muslim League (Qayyum), the Council Muslim League, and the Convention Muslim \\
League. Islamist Parties include the Jamiat Ulema-e-Islam, the Jamaat-e-Islami Pakistan, the Jamiat Ulema-e- \\
Pakistan, and the Jamiat Ahle Hadith.
\end{tabular}




\begin{tabular}{|cccc|}
\hline \multicolumn{4}{|c|}{ Table A2 - Survey data sources } \\
\hline Year & Survey & Source & Sample size \\
\hline 1988 & Gallup poll & Gallup Pakistan & 3064 \\
1993 & Gallup poll & Gallup Pakistan & 4589 \\
1997 & Gallup poll & Gallup Pakistan & 5286 \\
2002 & Gallup poll & Gallup Pakistan & 4617 \\
2008 & Gallup poll & Gallup Pakistan & 5405 \\
2013 & Gallup poll & Gallup Pakistan & 4636 \\
2018 & Gallup poll & Gallup Pakistan & 3549 \\
\hline Source: authors' elaboration. & \\
Note: the table shows the surveys used, the source from which these surveys can be \\
Obtained, and the sample size of each survey.
\end{tabular}




\begin{tabular}{|c|c|c|c|c|c|c|}
\hline \multicolumn{7}{|c|}{ Table A3 - Complete descriptive statistics } \\
\hline & 1988 & 1997 & 2002 & 2008 & 2013 & 2018 \\
\hline Education: None & $34 \%$ & $29 \%$ & $41 \%$ & $32 \%$ & $26 \%$ & $22 \%$ \\
\hline Education: Primary & $15 \%$ & $21 \%$ & $16 \%$ & $17 \%$ & $17 \%$ & $17 \%$ \\
\hline Education: Secondary & $42 \%$ & $50 \%$ & $35 \%$ & $44 \%$ & $48 \%$ & $51 \%$ \\
\hline Education: Tertiary & $9 \%$ & & $8 \%$ & $6 \%$ & $9 \%$ & $10 \%$ \\
\hline Language: Balochi & $4 \%$ & $4 \%$ & $4 \%$ & $4 \%$ & $4 \%$ & $4 \%$ \\
\hline Language: Others & $7 \%$ & $5 \%$ & $4 \%$ & $3 \%$ & $3 \%$ & $3 \%$ \\
\hline Language: Pashto & $15 \%$ & $15 \%$ & $15 \%$ & $15 \%$ & $15 \%$ & $15 \%$ \\
\hline Language: Punjabi & $44 \%$ & $44 \%$ & $44 \%$ & $44 \%$ & $44 \%$ & $44 \%$ \\
\hline Language: Saraekee & $11 \%$ & $11 \%$ & $10 \%$ & $10 \%$ & $10 \%$ & $10 \%$ \\
\hline Language: Sindhi & $12 \%$ & $14 \%$ & $15 \%$ & $15 \%$ & $16 \%$ & $16 \%$ \\
\hline Language: Urdu & $8 \%$ & $8 \%$ & $8 \%$ & $8 \%$ & $8 \%$ & $8 \%$ \\
\hline Location: Rural area & $69 \%$ & $68 \%$ & $66 \%$ & $65 \%$ & $64 \%$ & $63 \%$ \\
\hline Maslak: Sunni & $79 \%$ & $74 \%$ & $93 \%$ & $95 \%$ & $95 \%$ & $92 \%$ \\
\hline Province: Baluchistan & $5 \%$ & $5 \%$ & $5 \%$ & $5 \%$ & $5 \%$ & $6 \%$ \\
\hline Province: NWFP & $14 \%$ & $14 \%$ & $14 \%$ & $13 \%$ & $13 \%$ & $12 \%$ \\
\hline Province: Punjab & $58 \%$ & $57 \%$ & $57 \%$ & $57 \%$ & $56 \%$ & $54 \%$ \\
\hline Province: Sindh & $24 \%$ & $24 \%$ & $24 \%$ & $25 \%$ & $25 \%$ & $28 \%$ \\
\hline Religion: Muslim & $99 \%$ & & $97 \%$ & $98 \%$ & $97 \%$ & $97 \%$ \\
\hline \multicolumn{7}{|c|}{$\begin{array}{l}\text { Source: authors' computations using census statistics (region and language) and Pakistani polls (other variables). Census statistics ref } \\
\text { to the entire population; other variables refer to the voting population. } \\
\text { Note: the table shows descriptive statistics for selected available variables. The rise in the reported share of Sunni Muslims may } \\
\text { potentially be attributable to migration of the Shia population to Iran, as well as to the rise of anti-Shia sentiments and consolidation of } \\
\text { Sunni-supremacist organizations, leading to underreporting of Shia identity. }\end{array}$} \\
\hline
\end{tabular}




\begin{tabular}{|c|c|c|c|c|c|c|c|c|}
\hline \multicolumn{9}{|c|}{ Table A4 - Determinants of support for PPP, 1970-2018 } \\
\hline & $\begin{array}{c}(1) \\
1970\end{array}$ & $\begin{array}{c}(2) \\
1977\end{array}$ & $\begin{array}{c}(3) \\
1988\end{array}$ & $\begin{array}{c}(4) \\
1997\end{array}$ & $\begin{array}{c}(5) \\
2002\end{array}$ & $\begin{array}{c}(6) \\
2008\end{array}$ & $\begin{array}{c}(7) \\
2013\end{array}$ & $\begin{array}{c}(8) \\
2018\end{array}$ \\
\hline Language: Balochi & $\begin{array}{l}-0.067 \\
(0.086)\end{array}$ & $\begin{array}{l}-0.156^{\star} \\
(0.088)\end{array}$ & $\begin{array}{c}0.088^{*} \\
(0.049)\end{array}$ & $\begin{array}{c}0.022 \\
(0.020)\end{array}$ & $\begin{array}{c}0.121^{\star * *} \\
(0.029)\end{array}$ & $\begin{array}{c}0.411^{\star \star *} \\
(0.053)\end{array}$ & $\begin{array}{c}0.181^{\star * \star} \\
(0.026)\end{array}$ & $\begin{array}{c}0.004 \\
(0.013)\end{array}$ \\
\hline Language: Others & $\begin{array}{l}-0.057 \\
(0.041)\end{array}$ & $\begin{array}{l}-0.016 \\
(0.043)\end{array}$ & $\begin{array}{c}-0.158^{\star * *} \\
(0.027)\end{array}$ & $\begin{array}{c}-0.086^{\star * *} \\
(0.011)\end{array}$ & $\begin{array}{c}-0.013 \\
(0.029)\end{array}$ & $\begin{array}{c}0.051 \\
(0.039)\end{array}$ & $\begin{array}{c}-0.054^{* * *} \\
(0.010)\end{array}$ & $\begin{array}{c}-0.032^{* * *} \\
(0.010)\end{array}$ \\
\hline Language: Pashto & $\begin{array}{c}-0.073^{* *} \\
(0.033)\end{array}$ & $\begin{array}{l}-0.037 \\
(0.032)\end{array}$ & $\begin{array}{l}-0.039^{*} \\
(0.020)\end{array}$ & $\begin{array}{l}-0.033^{*} \\
(0.017)\end{array}$ & $\begin{array}{c}-0.080^{* * *} \\
(0.010)\end{array}$ & $\begin{array}{c}-0.131^{* * *} \\
(0.012)\end{array}$ & $\begin{array}{c}-0.039^{* * *} \\
(0.007)\end{array}$ & $\begin{array}{c}0.027^{* * *} \\
(0.009)\end{array}$ \\
\hline Language: Saraekee & $\begin{array}{c}-0.233^{\star * *} \\
(0.027)\end{array}$ & $\begin{array}{c}-0.148^{\star * *} \\
(0.030)\end{array}$ & $\begin{array}{c}-0.104^{\star * *} \\
(0.022)\end{array}$ & $\begin{array}{c}0.078^{* * *} \\
(0.014)\end{array}$ & $\begin{array}{c}0.161^{* * *} \\
(0.012)\end{array}$ & $\begin{array}{c}0.103^{* * *} \\
(0.019)\end{array}$ & $\begin{array}{c}0.070^{\star * *} \\
(0.011)\end{array}$ & $\begin{array}{c}-0.001 \\
(0.010)\end{array}$ \\
\hline Language: Sindhi & $\begin{array}{c}0.558^{\star * *} \\
(0.028)\end{array}$ & $\begin{array}{c}0.310^{* * *} \\
(0.027)\end{array}$ & $\begin{array}{c}0.485^{\star \star *} \\
(0.028)\end{array}$ & $\begin{array}{c}0.501^{\star * *} \\
(0.014)\end{array}$ & $\begin{array}{c}0.380^{* * *} \\
(0.015)\end{array}$ & $\begin{array}{c}0.526^{\star * *} \\
(0.014)\end{array}$ & $\begin{array}{c}0.420^{\star * *} \\
(0.015)\end{array}$ & $\begin{array}{c}0.460^{\star * *} \\
(0.018)\end{array}$ \\
\hline Language: Urdu & $\begin{array}{c}-0.145^{\star * *} \\
(0.026)\end{array}$ & $\begin{array}{c}-0.148^{\star * *} \\
(0.034)\end{array}$ & $\begin{array}{c}-0.136^{\star \star \star} \\
(0.020)\end{array}$ & $\begin{array}{c}-0.038^{\star * *} \\
(0.012)\end{array}$ & $\begin{array}{c}-0.087^{* * *} \\
(0.013)\end{array}$ & $\begin{array}{c}-0.120^{* * *} \\
(0.011)\end{array}$ & $\begin{array}{l}-0.001 \\
(0.008)\end{array}$ & $\begin{array}{l}0.023^{\star *} \\
(0.010)\end{array}$ \\
\hline Education: Primary & $\begin{array}{l}-0.056^{*} \\
(0.031)\end{array}$ & $\begin{array}{l}-0.037 \\
(0.026)\end{array}$ & $\begin{array}{c}-0.050^{* *} \\
(0.020)\end{array}$ & $\begin{array}{l}0.022^{*} \\
(0.012)\end{array}$ & $\begin{array}{c}0.006 \\
(0.010)\end{array}$ & $\begin{array}{c}-0.027^{\star *} \\
(0.013)\end{array}$ & $\begin{array}{c}-0.021^{* *} \\
(0.010)\end{array}$ & $\begin{array}{l}-0.012 \\
(0.012)\end{array}$ \\
\hline Education: Secondary & $\begin{array}{c}-0.014 \\
(0.027)\end{array}$ & $\begin{array}{c}-0.091^{\star * *} \\
(0.026)\end{array}$ & $\begin{array}{l}-0.001 \\
(0.018)\end{array}$ & $\begin{array}{l}-0.008 \\
(0.010)\end{array}$ & $\begin{array}{l}-0.011 \\
(0.009)\end{array}$ & $\begin{array}{c}-0.029^{* *} \\
(0.012)\end{array}$ & $\begin{array}{c}-0.018^{\star *} \\
(0.009)\end{array}$ & $\begin{array}{c}-0.030^{* \star *} \\
(0.009)\end{array}$ \\
\hline Education: Tertiary & $\begin{array}{c}-0.115^{\star \star *} \\
(0.041)\end{array}$ & $\begin{array}{c}-0.123^{\star *} \\
(0.048)\end{array}$ & $\begin{array}{c}0.038 \\
(0.029)\end{array}$ & $\begin{array}{c}0.000 \\
(.)\end{array}$ & $\begin{array}{l}-0.028^{*} \\
(0.016)\end{array}$ & $\begin{array}{l}-0.018 \\
(0.022)\end{array}$ & $\begin{array}{l}-0.023^{*} \\
(0.012)\end{array}$ & $\begin{array}{l}-0.005 \\
(0.016)\end{array}$ \\
\hline Income: Middle 40\% & $\begin{array}{c}-0.030 \\
(0.023)\end{array}$ & $\begin{array}{c}0.004 \\
(0.021)\end{array}$ & $\begin{array}{c}-0.049 * * * \\
(0.016)\end{array}$ & $\begin{array}{c}-0.012 \\
(0.008)\end{array}$ & $\begin{array}{c}0.013^{*} \\
(0.007)\end{array}$ & $\begin{array}{c}-0.020^{* *} \\
(0.009)\end{array}$ & $\begin{array}{c}-0.022^{* * *} \\
(0.006)\end{array}$ & $\begin{array}{c}0.003 \\
(0.008)\end{array}$ \\
\hline Income: Top 10\% & $\begin{array}{l}-0.059 \\
(0.043)\end{array}$ & $\begin{array}{l}-0.042 \\
(0.046)\end{array}$ & $\begin{array}{c}-0.086^{* *} \\
(0.034)\end{array}$ & $\begin{array}{l}-0.032^{*} \\
(0.018)\end{array}$ & $\begin{array}{l}-0.033 \\
(0.021)\end{array}$ & $\begin{array}{c}-0.086^{\star * *} \\
(0.018)\end{array}$ & $\begin{array}{l}-0.013 \\
(0.012)\end{array}$ & $\begin{array}{c}-0.003 \\
(0.015)\end{array}$ \\
\hline Rural area & $\begin{array}{c}0.052^{* * *} \\
(0.020)\end{array}$ & $\begin{array}{l}0.050^{* *} \\
(0.021)\end{array}$ & $\begin{array}{c}0.040^{\star * *} \\
(0.014)\end{array}$ & $\begin{array}{c}-0.016^{* *} \\
(0.008)\end{array}$ & $\begin{array}{c}-0.019 * * \\
(0.008)\end{array}$ & $\begin{array}{c}-0.044^{\star * *} \\
(0.009)\end{array}$ & $\begin{array}{c}0.055^{* * *} \\
(0.007)\end{array}$ & $\begin{array}{c}0.068^{* * *} \\
(0.008)\end{array}$ \\
\hline Age: $30-50$ & $\begin{array}{c}0.021 \\
(0.046)\end{array}$ & $\begin{array}{c}0.020 \\
(0.030)\end{array}$ & $\begin{array}{c}-0.046^{* * *} \\
(0.016)\end{array}$ & $\begin{array}{c}-0.033^{* * *} \\
(0.009)\end{array}$ & $\begin{array}{c}0.003 \\
(0.009)\end{array}$ & $\begin{array}{c}0.002 \\
(0.011)\end{array}$ & $\begin{array}{c}0.021^{* * *} \\
(0.007)\end{array}$ & $\begin{array}{l}-0.003 \\
(0.008)\end{array}$ \\
\hline Age: $51+$ & $\begin{array}{l}-0.047 \\
(0.048)\end{array}$ & $\begin{array}{c}0.035 \\
(0.033)\end{array}$ & $\begin{array}{l}-0.024 \\
(0.021)\end{array}$ & $\begin{array}{c}-0.056^{\star * *} \\
(0.012)\end{array}$ & $\begin{array}{c}0.010 \\
(0.012)\end{array}$ & $\begin{array}{l}-0.000 \\
(0.014)\end{array}$ & $\begin{array}{c}0.017 \\
(0.011)\end{array}$ & $\begin{array}{l}0.039 * * \\
(0.016)\end{array}$ \\
\hline Maslak: Shia & $\begin{array}{c}0.228^{* *} \\
(0.031)\end{array}$ & $\begin{array}{c}0.239^{\star * *} \\
(0.024)\end{array}$ & $\begin{array}{c}0.159^{\star * *} \\
(0.022)\end{array}$ & $\begin{array}{c}0.114^{* * *} \\
(0.025)\end{array}$ & $\begin{array}{c}0.109^{\star * *} \\
(0.016)\end{array}$ & $\begin{array}{c}0.014 \\
(0.021)\end{array}$ & $\begin{array}{c}0.021 \\
(0.016)\end{array}$ & $\begin{array}{c}0.071^{\star * *} \\
(0.020)\end{array}$ \\
\hline Constant & $\begin{array}{c}0.371^{\star * *} \\
(0.050)\end{array}$ & $\begin{array}{c}0.562^{\star * *} \\
(0.038)\end{array}$ & $\begin{array}{c}0.390 * * * \\
(0.022)\end{array}$ & $\begin{array}{c}0.217^{* * *} \\
(0.013)\end{array}$ & $\begin{array}{c}0.220^{* * *} \\
(0.013)\end{array}$ & $\begin{array}{c}0.320^{* * *} \\
(0.016)\end{array}$ & $\begin{array}{c}0.069^{* * *} \\
(0.012)\end{array}$ & $\begin{array}{c}0.021^{*} \\
(0.012)\end{array}$ \\
\hline R-squared & 0.21 & 0.13 & 0.15 & 0.19 & 0.10 & 0.21 & 0.16 & 0.27 \\
\hline
\end{tabular}




\begin{tabular}{|c|c|c|c|c|c|c|c|c|}
\hline \multicolumn{9}{|c|}{ Table A5 - Determinants of support for PML / IJI / PNA, 1970-2018 } \\
\hline & $\begin{array}{c}(1) \\
1970\end{array}$ & $\begin{array}{c}(2) \\
1977\end{array}$ & $\begin{array}{c}(3) \\
1988\end{array}$ & $\begin{array}{c}(4) \\
1997\end{array}$ & $\begin{array}{c}(5) \\
2002\end{array}$ & $\begin{array}{c}(6) \\
2008\end{array}$ & $\begin{array}{c}(7) \\
2013\end{array}$ & $\begin{array}{c}(8) \\
2018\end{array}$ \\
\hline Language: Balochi & $\begin{array}{c}-0.140^{\star *} \\
(0.067)\end{array}$ & $\begin{array}{l}-0.009 \\
(0.077)\end{array}$ & $\begin{array}{c}-0.374^{\star \star \star} \\
(0.029)\end{array}$ & $\begin{array}{c}-0.253^{* * *} \\
(0.023)\end{array}$ & $\begin{array}{l}-0.014 \\
(0.035)\end{array}$ & $\begin{array}{c}-0.449^{* * *} \\
(0.043)\end{array}$ & $\begin{array}{c}-0.370^{\star * \star} \\
(0.023)\end{array}$ & $\begin{array}{c}-0.341^{\star \star \star} \\
(0.020)\end{array}$ \\
\hline Language: Others & $\begin{array}{c}0.006 \\
(0.036)\end{array}$ & $\begin{array}{c}0.018 \\
(0.042)\end{array}$ & $\begin{array}{l}-0.021 \\
(0.029)\end{array}$ & $\begin{array}{c}-0.141^{* * *} \\
(0.020)\end{array}$ & $\begin{array}{l}-0.065^{\star} \\
(0.034)\end{array}$ & $\begin{array}{c}-0.210^{\star * *} \\
(0.049)\end{array}$ & $\begin{array}{l}-0.010 \\
(0.027)\end{array}$ & $\begin{array}{c}-0.122^{\star \star *} \\
(0.035)\end{array}$ \\
\hline Language: Pashto & $\begin{array}{c}-0.080^{* * *} \\
(0.029)\end{array}$ & $\begin{array}{c}0.033 \\
(0.031)\end{array}$ & $\begin{array}{c}-0.270^{* * *} \\
(0.019)\end{array}$ & $\begin{array}{c}-0.305^{* * *} \\
(0.019)\end{array}$ & $\begin{array}{c}-0.278^{* * *} \\
(0.012)\end{array}$ & $\begin{array}{c}-0.216^{* * *} \\
(0.025)\end{array}$ & $\begin{array}{c}-0.355^{\star * *} \\
(0.013)\end{array}$ & $\begin{array}{c}-0.338^{* * *} \\
(0.015)\end{array}$ \\
\hline Language: Saraekee & $\begin{array}{c}0.056^{*} \\
(0.031)\end{array}$ & $\begin{array}{c}0.138^{\star \star *} \\
(0.029)\end{array}$ & $\begin{array}{c}-0.120^{\star * *} \\
(0.021)\end{array}$ & $\begin{array}{c}-0.117^{\star \star *} \\
(0.015)\end{array}$ & $\begin{array}{c}-0.158^{* \star *} \\
(0.013)\end{array}$ & $\begin{array}{c}-0.125^{\star \star \star} \\
(0.023)\end{array}$ & $\begin{array}{c}-0.234^{\star * *} \\
(0.016)\end{array}$ & $\begin{array}{c}-0.081^{* * *} \\
(0.023)\end{array}$ \\
\hline Language: Sindhi & $\begin{array}{c}-0.244^{* * *} \\
(0.018)\end{array}$ & $\begin{array}{c}-0.290^{* * *} \\
(0.027)\end{array}$ & $\begin{array}{c}-0.309^{\star * *} \\
(0.027)\end{array}$ & $\begin{array}{c}-0.415^{\star * *} \\
(0.013)\end{array}$ & $\begin{array}{c}-0.259^{\star * *} \\
(0.016)\end{array}$ & $\begin{array}{c}-0.445^{\star * *} \\
(0.013)\end{array}$ & $\begin{array}{c}-0.481^{* * *} \\
(0.010)\end{array}$ & $\begin{array}{c}-0.332^{\star * *} \\
(0.016)\end{array}$ \\
\hline Language: Urdu & $\begin{array}{l}-0.041 \\
(0.028)\end{array}$ & $\begin{array}{c}0.092^{\star * \star} \\
(0.034)\end{array}$ & $\begin{array}{l}-0.015 \\
(0.023)\end{array}$ & $\begin{array}{c}-0.333^{\star \star \star} \\
(0.015)\end{array}$ & $\begin{array}{c}-0.209^{* \star *} \\
(0.015)\end{array}$ & $\begin{array}{c}-0.171^{\star \star \star} \\
(0.017)\end{array}$ & $\begin{array}{c}-0.332^{\star \star *} \\
(0.016)\end{array}$ & $\begin{array}{c}-0.209^{* * *} \\
(0.022)\end{array}$ \\
\hline Education: Primary & $\begin{array}{c}0.007 \\
(0.027)\end{array}$ & $\begin{array}{l}0.049^{*} \\
(0.026)\end{array}$ & $\begin{array}{l}0.032^{*} \\
(0.019)\end{array}$ & $\begin{array}{c}0.020 \\
(0.013)\end{array}$ & $\begin{array}{c}0.008 \\
(0.012)\end{array}$ & $\begin{array}{c}0.045^{* * *} \\
(0.016)\end{array}$ & $\begin{array}{c}0.010 \\
(0.014)\end{array}$ & $\begin{array}{c}0.029 \\
(0.021)\end{array}$ \\
\hline Education: Secondary & $\begin{array}{l}0.048^{* *} \\
(0.023)\end{array}$ & $\begin{array}{c}0.090^{\star * *} \\
(0.025)\end{array}$ & $\begin{array}{c}0.066^{* * *} \\
(0.018)\end{array}$ & $\begin{array}{c}0.032^{\star \star *} \\
(0.011)\end{array}$ & $\begin{array}{c}-0.034^{\star * *} \\
(0.011)\end{array}$ & $\begin{array}{c}0.058^{\star \star *} \\
(0.016)\end{array}$ & $\begin{array}{c}0.009 \\
(0.012)\end{array}$ & $\begin{array}{l}-0.013 \\
(0.018)\end{array}$ \\
\hline Education: Tertiary & $\begin{array}{l}-0.012 \\
(0.032)\end{array}$ & $\begin{array}{c}0.134^{\star * *} \\
(0.047)\end{array}$ & $\begin{array}{c}0.025 \\
(0.027)\end{array}$ & $\begin{array}{c}0.000 \\
(.)\end{array}$ & $\begin{array}{c}0.005 \\
(0.019)\end{array}$ & $\begin{array}{c}0.131^{\star * *} \\
(0.028)\end{array}$ & $\begin{array}{l}-0.013 \\
(0.020)\end{array}$ & $\begin{array}{l}-0.043 \\
(0.028)\end{array}$ \\
\hline Income: Middle 40\% & $\begin{array}{l}-0.014 \\
(0.019)\end{array}$ & $\begin{array}{l}-0.001 \\
(0.020)\end{array}$ & $\begin{array}{l}-0.010 \\
(0.015)\end{array}$ & $\begin{array}{c}-0.029^{* * *} \\
(0.009)\end{array}$ & $\begin{array}{c}-0.021^{* * *} \\
(0.008)\end{array}$ & $\begin{array}{c}0.070^{* * *} \\
(0.012)\end{array}$ & $\begin{array}{c}-0.061^{* * *} \\
(0.009)\end{array}$ & $\begin{array}{c}0.013 \\
(0.014)\end{array}$ \\
\hline Income: Top 10\% & $\begin{array}{c}0.008 \\
(0.042)\end{array}$ & $\begin{array}{c}0.037 \\
(0.045)\end{array}$ & $\begin{array}{l}-0.017 \\
(0.031)\end{array}$ & $\begin{array}{c}-0.087^{* * *} \\
(0.022)\end{array}$ & $\begin{array}{c}0.009 \\
(0.025)\end{array}$ & $\begin{array}{c}0.065^{\star} \\
(0.036)\end{array}$ & $\begin{array}{l}-0.042^{*} \\
(0.022)\end{array}$ & $\begin{array}{l}0.059^{* *} \\
(0.028)\end{array}$ \\
\hline Rural area & $\begin{array}{c}0.061^{\star * *} \\
(0.020)\end{array}$ & $\begin{array}{c}-0.067^{* \star *} \\
(0.021)\end{array}$ & $\begin{array}{c}0.161^{* * *} \\
(0.015)\end{array}$ & $\begin{array}{c}-0.078^{\star * *} \\
(0.010)\end{array}$ & $\begin{array}{c}0.095^{\star * *} \\
(0.010)\end{array}$ & $\begin{array}{c}0.099^{\star * *} \\
(0.012)\end{array}$ & $\begin{array}{c}-0.066^{\star \star *} \\
(0.011)\end{array}$ & $\begin{array}{l}-0.015 \\
(0.015)\end{array}$ \\
\hline Age: $30-50$ & $\begin{array}{c}0.016 \\
(0.042)\end{array}$ & $\begin{array}{l}-0.016 \\
(0.029)\end{array}$ & $\begin{array}{c}0.051^{\star * *} \\
(0.015)\end{array}$ & $\begin{array}{c}0.065^{\star * *} \\
(0.011)\end{array}$ & $\begin{array}{l}0.022^{* *} \\
(0.010)\end{array}$ & $\begin{array}{c}-0.042^{* * *} \\
(0.015)\end{array}$ & $\begin{array}{c}0.012 \\
(0.011)\end{array}$ & $\begin{array}{l}0.029^{* *} \\
(0.014)\end{array}$ \\
\hline Age: $51+$ & $\begin{array}{c}0.044 \\
(0.044)\end{array}$ & $\begin{array}{l}-0.026 \\
(0.033)\end{array}$ & $\begin{array}{l}0.049 * * \\
(0.020)\end{array}$ & $\begin{array}{c}0.080^{\star * *} \\
(0.015)\end{array}$ & $\begin{array}{c}0.008 \\
(0.013)\end{array}$ & $\begin{array}{l}-0.035^{*} \\
(0.021)\end{array}$ & $\begin{array}{c}0.044^{\star * *} \\
(0.016)\end{array}$ & $\begin{array}{c}0.002 \\
(0.024)\end{array}$ \\
\hline Maslak: Shia & $\begin{array}{l}-0.000 \\
(0.027)\end{array}$ & $\begin{array}{c}-0.250^{\star \star *} \\
(0.023)\end{array}$ & $\begin{array}{c}-0.136^{\star * *} \\
(0.018)\end{array}$ & $\begin{array}{c}-0.098^{\star * *} \\
(0.024)\end{array}$ & $\begin{array}{l}-0.011 \\
(0.017)\end{array}$ & $\begin{array}{c}0.002 \\
(0.029)\end{array}$ & $\begin{array}{l}-0.030 \\
(0.021)\end{array}$ & $\begin{array}{c}-0.054^{\star *} \\
(0.027)\end{array}$ \\
\hline Constant & $\begin{array}{c}0.171^{* * *} \\
(0.047)\end{array}$ & $\begin{array}{c}0.414^{* * *} \\
(0.037)\end{array}$ & $\begin{array}{c}0.248^{* * *} \\
(0.022)\end{array}$ & $\begin{array}{c}0.644^{* * *} \\
(0.016)\end{array}$ & $\begin{array}{c}0.421^{* * *} \\
(0.014)\end{array}$ & $\begin{array}{c}0.463^{* * *} \\
(0.021)\end{array}$ & $\begin{array}{c}0.589^{* * *} \\
(0.017)\end{array}$ & $\begin{array}{c}0.397^{* * *} \\
(0.026)\end{array}$ \\
\hline R-squared & 0.05 & 0.12 & 0.10 & 0.12 & 0.07 & 0.12 & 0.16 & 0.11 \\
\hline
\end{tabular}




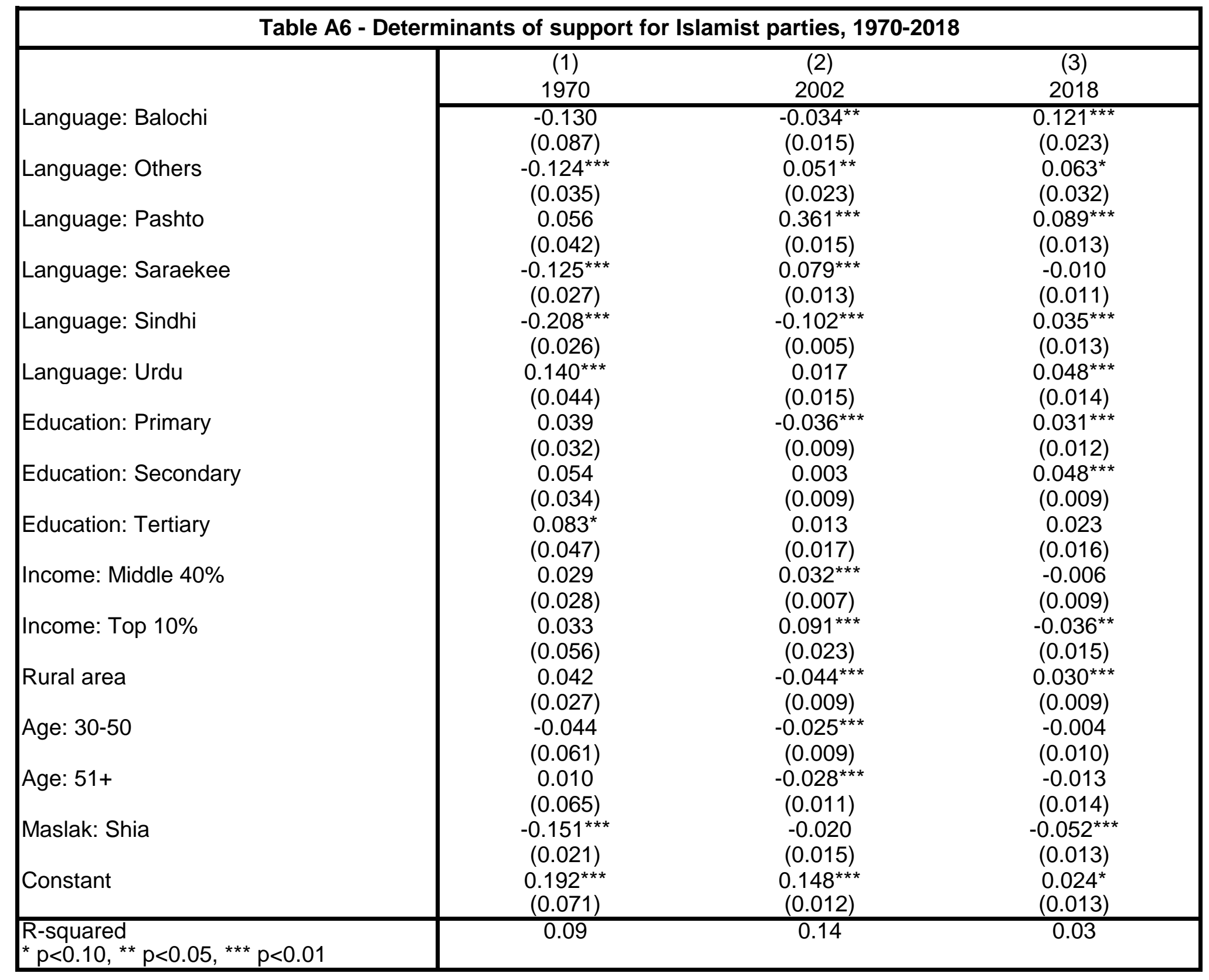




\begin{tabular}{|c|c|c|}
\hline \multicolumn{3}{|c|}{ Table A7 - Determinants of support for PTI, 2013-2018 } \\
\hline & $\begin{array}{c}(1) \\
2013\end{array}$ & $\begin{array}{c}(2) \\
2018\end{array}$ \\
\hline Language: Balochi & $\begin{array}{l}-0.174^{\star \star \star} \\
(0.008)\end{array}$ & $\begin{array}{l}-0.158^{\star \star \star} \\
(0.023)\end{array}$ \\
\hline Language: Others & $\begin{array}{c}0.141^{* * *} \\
(0.025)\end{array}$ & $\begin{array}{l}0.088^{* * *} \\
(0.034)\end{array}$ \\
\hline Language: Pashto & $\begin{array}{c}0.047^{* \star *} \\
(0.013)\end{array}$ & $\begin{array}{c}0.229^{* * *} \\
(0.020)\end{array}$ \\
\hline Language: Saraekee & $\begin{array}{l}-0.018 \\
(0.013)\end{array}$ & $\begin{array}{c}0.075^{\star * *} \\
(0.022)\end{array}$ \\
\hline Language: Sindhi & $\begin{array}{c}-0.126^{* * *} \\
(0.010)\end{array}$ & $\begin{array}{c}-0.076^{\star * \star} \\
(0.019)\end{array}$ \\
\hline Language: Urdu & $\begin{array}{c}-0.054^{* * *} \\
(0.014)\end{array}$ & $\begin{array}{l}-0.032 \\
(0.021)\end{array}$ \\
\hline Education: Primary & $\begin{array}{l}-0.002 \\
(0.011)\end{array}$ & $\begin{array}{l}0.037^{*} \\
(0.019)\end{array}$ \\
\hline Education: Secondary & $\begin{array}{c}0.035^{\star \star \star} \\
(0.010)\end{array}$ & $\begin{array}{c}0.109^{* \star *} \\
(0.017)\end{array}$ \\
\hline Education: Tertiary & $\begin{array}{l}0.111^{* * *} \\
(0.019)\end{array}$ & $\begin{array}{l}0.183^{* * *} \\
(0.030)\end{array}$ \\
\hline Income: Middle $40 \%$ & $\begin{array}{l}0.018^{* *} \\
(0.008)\end{array}$ & $\begin{array}{l}0.028^{* *} \\
(0.014)\end{array}$ \\
\hline Income: Top $10 \%$ & $\begin{array}{c}0.062^{* * *} \\
(0.019)\end{array}$ & $\begin{array}{c}0.041 \\
(0.029)\end{array}$ \\
\hline Rural area & $\begin{array}{c}-0.038^{* * *} \\
(0.010)\end{array}$ & $\begin{array}{c}0.025 \\
(0.015)\end{array}$ \\
\hline Age: $30-50$ & $\begin{array}{c}-0.068^{\star * *} \\
(0.010)\end{array}$ & $\begin{array}{l}-0.030^{* *} \\
(0.015)\end{array}$ \\
\hline Age: $51+$ & $\begin{array}{c}-0.094^{* * *} \\
(0.013)\end{array}$ & $\begin{array}{c}0.011 \\
(0.024)\end{array}$ \\
\hline Maslak: Shia & $\begin{array}{c}-0.048^{* * *} \\
(0.014)\end{array}$ & $\begin{array}{l}0.080^{* *} \\
(0.032)\end{array}$ \\
\hline Constant & $\begin{array}{c}0.228^{* * *} \\
(0.015)\end{array}$ & $\begin{array}{c}0.200^{* * *} \\
(0.023)\end{array}$ \\
\hline $\begin{array}{l}\text { R-squared } \\
{ }^{*} p<0.10,{ }^{* *} p<0.05,{ }^{* * *} p<0.01\end{array}$ & 0.05 & 0.06 \\
\hline
\end{tabular}

